\title{
WATER LEVELS IN THE CALUMET AQUIFER AND \\ THEIR RELATION TO \\ SURFACE-WATER LEVELS IN NORTHERN LAKE COUNTY, INDIANA, 1985-92
}

By THEODORE K. GREEMAN

Prepared in cooperation with the INDIANA DEPARTMENT OF ENVIRONMENTAL MANAGEMENT

U.S. GEOLOGICAL SURVEY

Water-Resources Investigations Report 94-4110

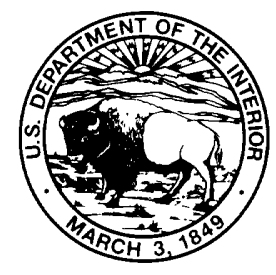

Indianapolis, Indiana 


\title{
U.S. DEPARTMENT OF THE INTERIOR BRUCE BABBITT, Secretary
}

\author{
U.S. GEOLOGICAL SURVEY \\ Gordon P. Eaton, Director
}

For additional information, write to:

District Chief

U.S. Geological Survey

Water Resources Division

5957 Lakeside Boulevard

Indianapolis, IN 46278-1996
Copies of this report can be purchased from:

U.S. Geological Survey Earth Science Information Center Open-File Reports Section Box 25286, MS 517 Denver Federal Center Denver, CO 80225 


\section{CONTENTS}

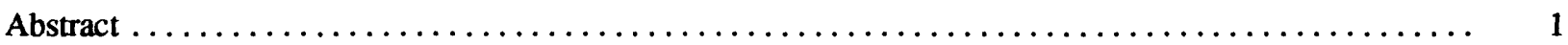

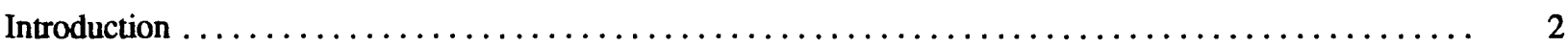

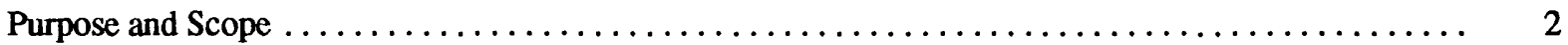

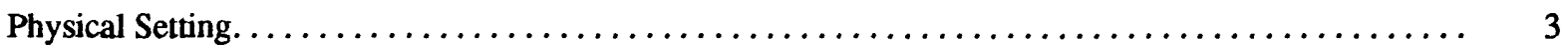

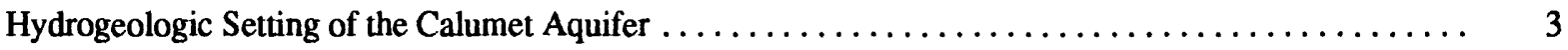

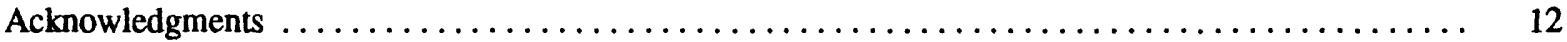

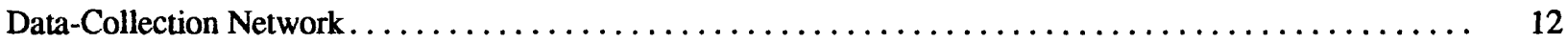

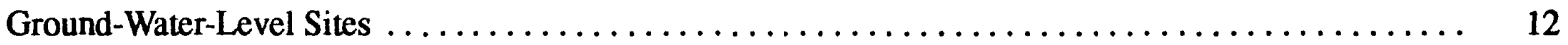

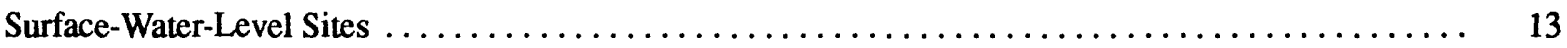

Ground-Water Levels and Their Relation to Surface-Water Levels $\ldots \ldots \ldots \ldots \ldots \ldots \ldots \ldots \ldots \ldots \ldots \ldots$

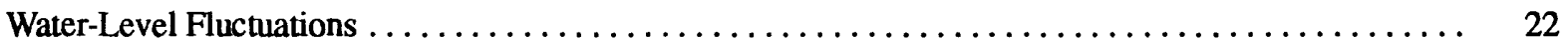

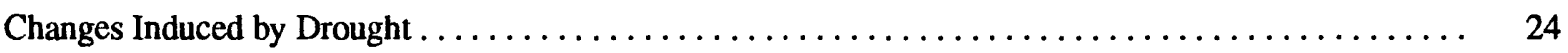

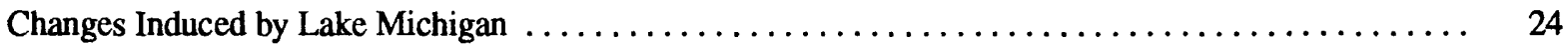

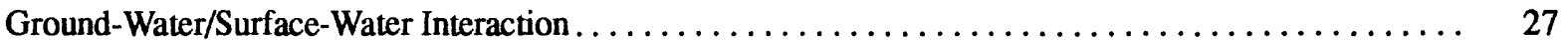

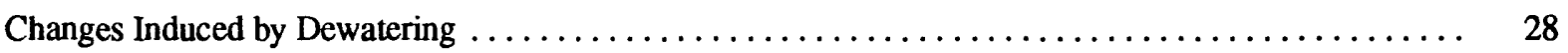

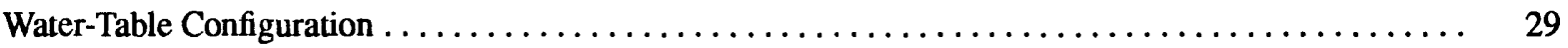

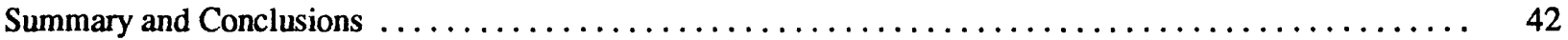

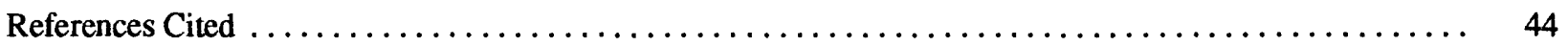

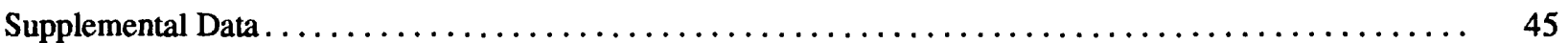

\section{FIGURES}

1-4. Maps showing:

1. Surface water and cultural features in the study area..................... 4

2. Locations of wells and surface-water sites, northern Lake County, Indiana . . . . . . . . 6

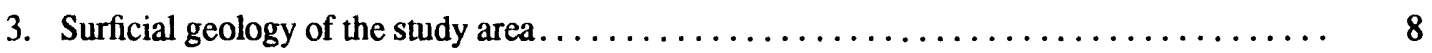

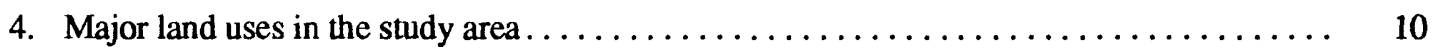

5. Ground-water hydrograph showing the daily effects of evapotranspiration $\ldots \ldots \ldots \ldots \ldots \ldots 23$

6. Difference in water levels between deep and shallow wells, northern Lake County, Indiana ..... 25

7. Graphs showing monthly precipitation data for Hobart, Indiana $\ldots \ldots \ldots \ldots \ldots \ldots \ldots \ldots$

8-13. Maps showing water table in the Calumet aquifer:

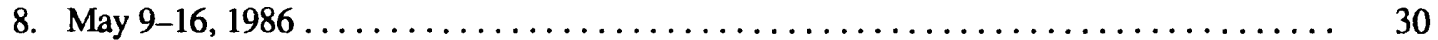

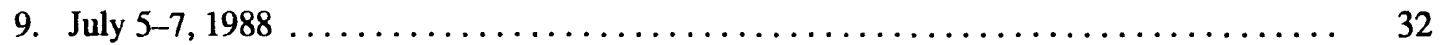

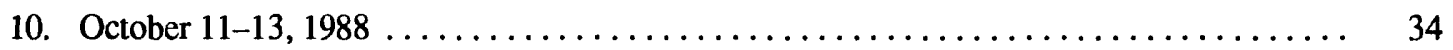

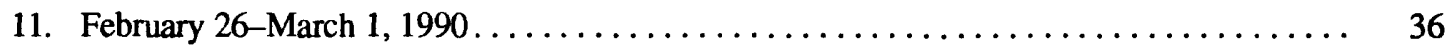

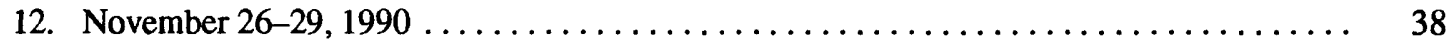

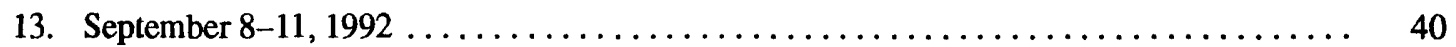




\section{CONTENTS}

\section{TABLES}

1. Characteristics of observation wells completed in the Calumet aquifer, northern

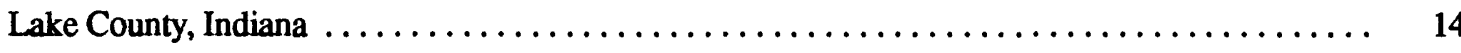

2. Location and description of surface-water-stage measurement sites in northern

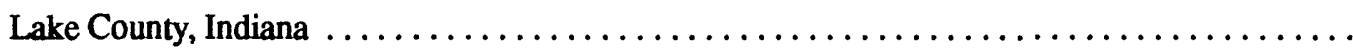

3. Summary statistics for ground-water-level measurements in the Calumet aquifer,

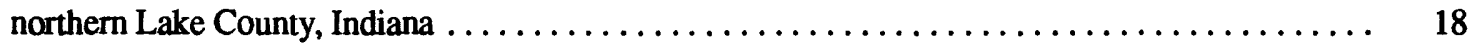

4. Summary statistics for surface-water-level measurements in northern Lake County, Indiana ..... 21

5. Water levels in selected wells in the Calumet aquifer and surface-water sites in northern Lake County, Indiana, August 1985 through October 1992 
CONVERSION FACTORS, VERTICAL DATUM, AND ABBREVIATIONS

\begin{tabular}{rll}
\hline Muitiply & By & To Obtain \\
\hline inch (in) & 25.4 & millimeter \\
inch per year (in/yr) & 25.4 & millimeter per year \\
foot (ft) & 0.3048 & meter \\
foot per day (ft/d) & 0.3048 & meter per day \\
mile (mi) & 1.609 & kilometer \\
\hline
\end{tabular}

Temperature is given in degrees Fahrenheit $\left({ }^{\circ} \mathrm{F}\right)$ which may be converted to degrees Celsius $\left({ }^{\circ} \mathrm{C}\right)$ as follows:

$$
{ }^{\circ} \mathrm{C}=\left({ }^{\circ} \mathrm{F}-32\right) 0.556
$$

Sea level: In this report, "sea level" refers to the National Geodetic Vertical Datum of 1929 (NGVD of 1929)-a geodetic datum derived from a general adjustment of the first-order level nets of the United States and Canada, formerly called Sea Level Datum of 1929. 
$\sin ^{2} x^{2} 6^{2}$ 


\title{
Water Levels in the Calumet Aquifer and Their Relation to Surface-Water Levels in Northern Lake County, Indiana, 1985-92
}

\author{
By Theodore K. Greeman
}

\begin{abstract}
The U.S. Geological Survey made 2,328 water-level measurements at a total of 96 ground-water and surface-water sites in northern Lake County, Indiana, from August 1985 through September 1992. This report lists and summarizes the significance of the measurements. Northern Lake County is on the southern shore of Lake Michigan and includes the cities of East Chicago, Gary, Hammond, and Whiting. The study area is underlain by the unconfined Calumet aquifer and receives about 36 inches of precipitation per year.
\end{abstract}

The U.S. Geological Survey investigated ground-water levels and flow in the Calumet aquifer and the effect of Lake Michigan levels on ground-water and surface-water levels throughout the study area. Summary statistics of the water-level data were computed for each site.

Ground-water levels annually reach a maximum in June or July and a minimum in September or October. Measured groundwater fluctuations in the Calumet aquifer during the study period ranged from 0.40 to $5.01 \mathrm{feet}$, and the mean ground-water fluctuation was about 2.3 feet. The largest surface-water fluctuations were affected by record setting Lake Michigan levels. Midmonth daily averages for the data-collection period show that Lake Michigan fluctuated 4.14 feet. Water-level fluctuations on the Grand Calumet River were from 1.06 to 2.45 feet.
Analysis of water-level data indicates that the 1988 drought did not substantially affect water levels in the Calumet aquifer, but the deficit in precipitation reversed vertical flow gradients in ground water at three paired deep and shallow wells. High water levels in Lake Michigan during 1985-87 created long-term backwater effects on the Grand Calumet River as far as 11.0 miles upstream from Lake Michigan.

Analysis of water-level data from the data-collection network indicates that the water table normally slopes toward streams, ditches, sewers, the Indiana Harbor Canal, and Lake Michigan. The slope of the water table toward the Grand Calumet River is greatest in the winter and can decrease to being almost horizontal in the summer. Wells near streams respond quickly to nearby surface-water-level changes. Water-table maps indicate that sewers and dewatering systems are lowering ground-water levels in large areas. Ditches, the Grand Calumet River, and the Indiana Harbor Canal connect the Lake Michigan water level to large parts of the study area. The surface-water stage in the Indiana Harbor Canal, which functions as a ditch, can equal Lake Michigan's stage up to 3.75 miles inland from the lakeshore. Human activity, the stage of Lake Michigan, and the storage capacity of the Calumet aquifer combine to reduce vertical changes in the water table in the study area. 


\section{INTRODUCTION}

Northern Lake County, Ind., (fig. 1), is on the southern shore of Lake Michigan and is accessible to major shipping routes. This area, which includes the cities of Gary, Hammond, East Chicago, and Whiting, is one of the most industrialized and urbanized regions in the United States. Large-scale industries in the area include steel mills, petrochemical refineries, chemical plants, coal-fired electric-generating plants, and factories. Before development, much of the area consisted of bogs and marshes separated by former beach ridges. As the area was developed, many wetlands were drained, most beach ridges were leveled, new drainage outlets were opened to Lake Michigan, and rivers were dredged. Large areas along the Lake Michigan shoreline and the low wetland areas were filled with slag, a by-product of steel production. Lake-fill land extends more than $2 \mathrm{mi}$ into Lake Michigan in some places. Urban development in the study area has disrupted ground-water flow in the Calumet aquifer and altered surface-water drainage patterns in the study area (Watson and others, 1989, p. 30).

In many parts of the area, steel and petrochemical production has adversely affected the water quality (Fenelon and Watson, 1993, p. 70). The U.S. Environmental Protection Agency (USEPA) and the Indiana Department of Environmental Management (IDEM) are involved in numerous investigations of ground-water and surface-water quality in this area.

The U.S. Geological Survey (USGS) began collecting water-level data in August 1985 from a network of ground-water- and surfacewater-level monitoring sites (fig. 2) near the Grand Calumet River, the Indiana Harbor Canal, and Lake Michigan. A primary purpose of that study was to determine the potential for groundwater contaminants to enter Lake Michigan (Fenelon and Watson, 1993, p. 4). In addition to monthly and bimonthly measurements made at 78 sites, hourly water levels were recorded at 22 sites from August 1985 through October 1986.
After several new wells were installed, quarterly measurements were made at 99 sites from October 1986 through August 1988. The USGS, in cooperation with IDEM, measured water levels in the network quarterly from October 1988 through September 1992.

Results of these previous investigations of contaminant loads in the Grand Calumet River and the Indiana Harbor Canal indicated that ground-water discharge is a contributor to the surface-water contaminant load (Crawford and Wangsness, 1987, p. 121; Fenelon and Watson, 1993, p. 70); however, additional analysis of water levels in the Calumet aquifer (fig. 3) and surfacewater bodies nearby was necessary to determine ground-water flow directions. Interpretations of the changes in water levels are important for defining hydrologic conditions that affect engineered and natural restoration of groundand surface-water quality.

Consequently, the USGS, in cooperation with IDEM, began a project in 1992 to analyze all ground-water and surface-water data collected in northern Lake County, Ind., from August 1985 through September 30, 1992. In addition to the hourly data, a total of 2,328 ground-water and surface-water measurements were made-about 25 measurements per site.

\section{Purpose and Scope}

This report presents an analyses of all the data collected from the ground-water and surfacewater network. Analyses of these water-level data include (1) a statistical summary of water-level fluctuations measured at each site, (2) a hydrologic comparison of water levels during a drought, (3) a hydrologic comparison of water levels in relation to Lake Michigan levels, (4) an examination of the interaction of ground water and surface water, (5) a determination of where dewatering has lowered water-level altitudes, and (6) a comparison of water-table contour maps from several time periods. Data are reported in tables, hydrographs, and water-table maps. 


\section{Physical Setting}

The study area (fig. 3) is entirely within the Calumet Lacustrine Plain physiographic area (Malott, 1922, p. 113). The Calumet Lacustrine Plain extends southward from the shoreline of Lake Michigan to the northern edge of the Valparaiso moraine, a distance of about $12 \mathrm{mi}$ along the Indiana-Illinois State line and $3 \mathrm{mi}$ along the Lake-Porter County line (fig. 3). Most areas of the Calumet Lacustrine Plain, which is the former bed of glacial Lake Chicago, have low relief. Relic shorelines capped by sand dunes represent successively lowered water levels of post-Pleistocene Lake Chicago (Hartke and others, 1975, p. 2). Some dune ridges rise $40 \mathrm{ft}$ above the surrounding plain. Historically, major transportation routes through this area developed atop these dune ridges. Swampy areas formerly occupied the lowlands between the dunes. The study area is now largely drained, filled, and heavily urbanized (fig. 4). Many isolated areas, however, remain natural. Major land uses in the study area are discussed by Watson and others $(1989$, p. 8-11).

The area at the southern end of Lake Michigan receives about 36 in. of precipitation per year (National Oceanic and Atmospheric Administration, 1982) and has a continental climate characterized by hot humid summers and cold winters. Snowfall averages 30 to 40 in. annually. Precipitation is distributed evenly throughout the year, monthly averages range from $1.46 \mathrm{in}$. for February to 3.84 in. for June and July (National Oceanic and Atmospheric Administration, 1982). The mean January temperature is $24^{\circ} \mathrm{F}$ and the mean July temperature is $73^{\circ} \mathrm{F}$ (National Oceanic and Atmospheric Administration, 1982).

\section{Hydrogeologic Setting of the Calumet Aquifer}

The study area (fig. 3) is underlain by beach deposits consisting of wind- and water-deposited fine sand and silt, which comprise the unconfined Calumet aquifer (Hartke and others, 1975, p. 7). The aquifer extends south from Lake Michigan and underlies the northern third of Lake County.
The Calumet aquifer also extends eastward into Porter County, Ind., in a narrow strip along Lake Michigan and west into Cook County, Ill. (Hartke and others, 1975, p. 7). The Calumet aquifer has been deposited from late Wisconsinan to the present. As a source of water, the Calumet aquifer is used only for domestic supply in unincorporated areas; municipal and industrial water supplies are withdrawn from Lake Michigan.

In northern Lake County, the thickness of the Calumet aquifer ranges from 0 to $65 \mathrm{ft}$ (Watson and others, 1989, p. 18) and averages $20 \mathrm{ft}$ (Hartke and others, 1975, p. 25). The aquifer is thickest in the eastern part of the study area (Watson and others, 1989, p. 18). Sand was exposed at the land surface throughout most of the area, although peat and muck filled some low areas. Much of the sand now is covered with fill materials that were placed on the ground to raise the land surface above the water table. Fenelon and Watson (1993, p. 18) report on several previous aquifer tests done as part of site-specific hydrologic investigations within the study area. They report the horizontal hydraulic conductivity of the aquifer ranges from less than $1 \mathrm{ft} / \mathrm{d}$ to $180 \mathrm{ft} / \mathrm{d}$ and averages $60 \mathrm{ft} / \mathrm{d}$. One aquifer test reported by Fenelon and Watson indicated a vertical hydraulic conductivity of 3 to $4 \mathrm{ft} / \mathrm{d}$ and an estimated 15:1 ratio of horizontal to vertical hydraulic conductivity.

The estimated storage coefficient for the Calumet aquifer is 0.12 (Rosenshein and Hunn, 1968 , p. 29). In an unconfined aquifer, the storage coefficient is equal to the specific yield; thus, the aquifer will yield about 12 percent water by volume. Evapotranspiration and runoff within the study area are estimated to be $25 \mathrm{in} / \mathrm{yr}$, and recharge is about $12 \mathrm{in} / \mathrm{yr}$ (Hartke and others, 1975, p. 16). The 12 to $17 \mathrm{in} / \mathrm{yr}$ recharge estimates (Fenelon and Watson, 1993, p. 35), in conjunction with the low relief on the water table, are indicators of the relatively high permeability of the Calumet aquifer. Regional ground-water flow in the Calumet aquifer generally is toward the major streams, the Indiana Harbor Canal, and Lake Michigan. The Grand Calumet River and the Little Calumet River are the only streams draining the area; all other channels are artificial. 


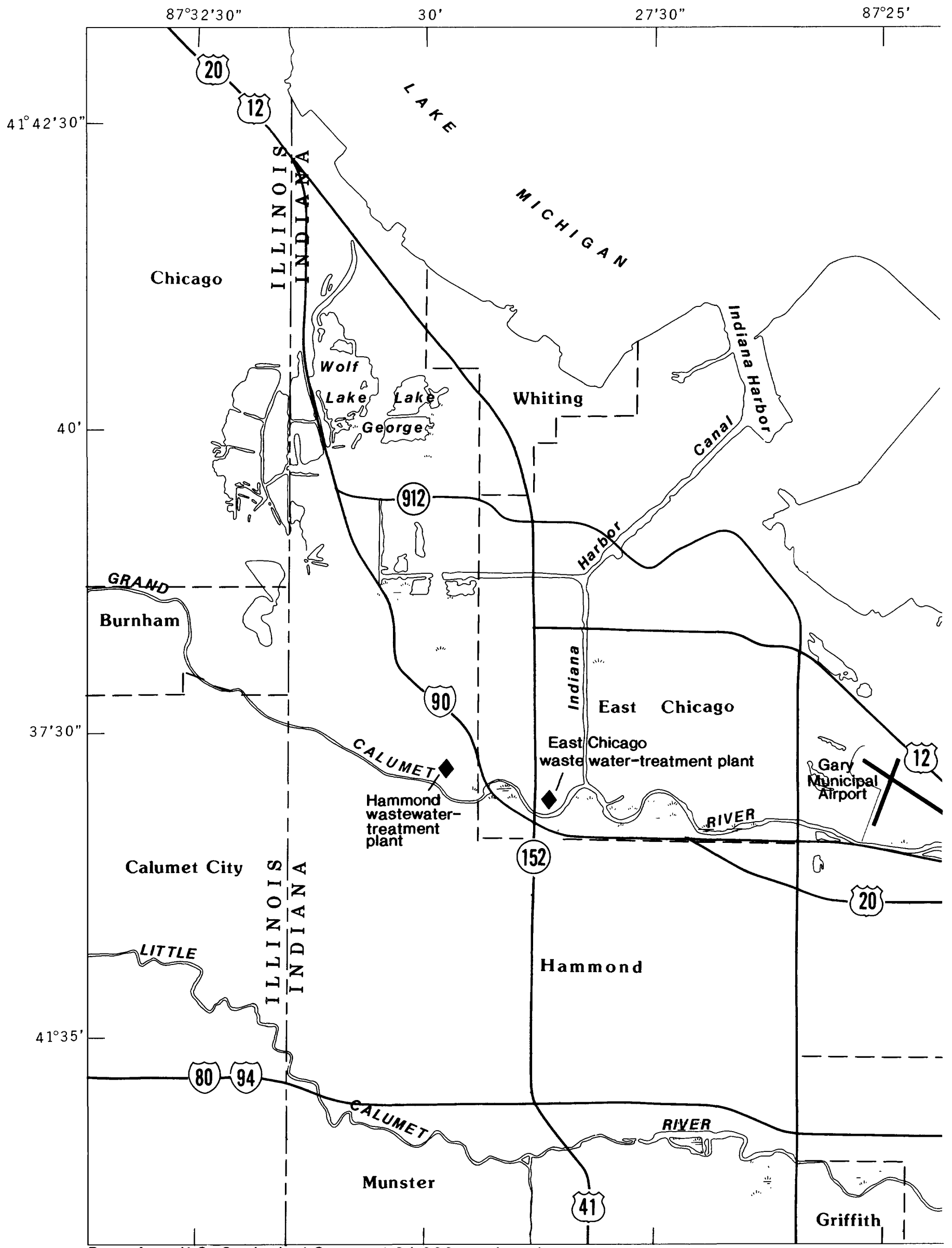

Base from U.S. Geological Survey 1:24,000 quadrangles

Figure 1. Surface water and cultural features in the study area. 


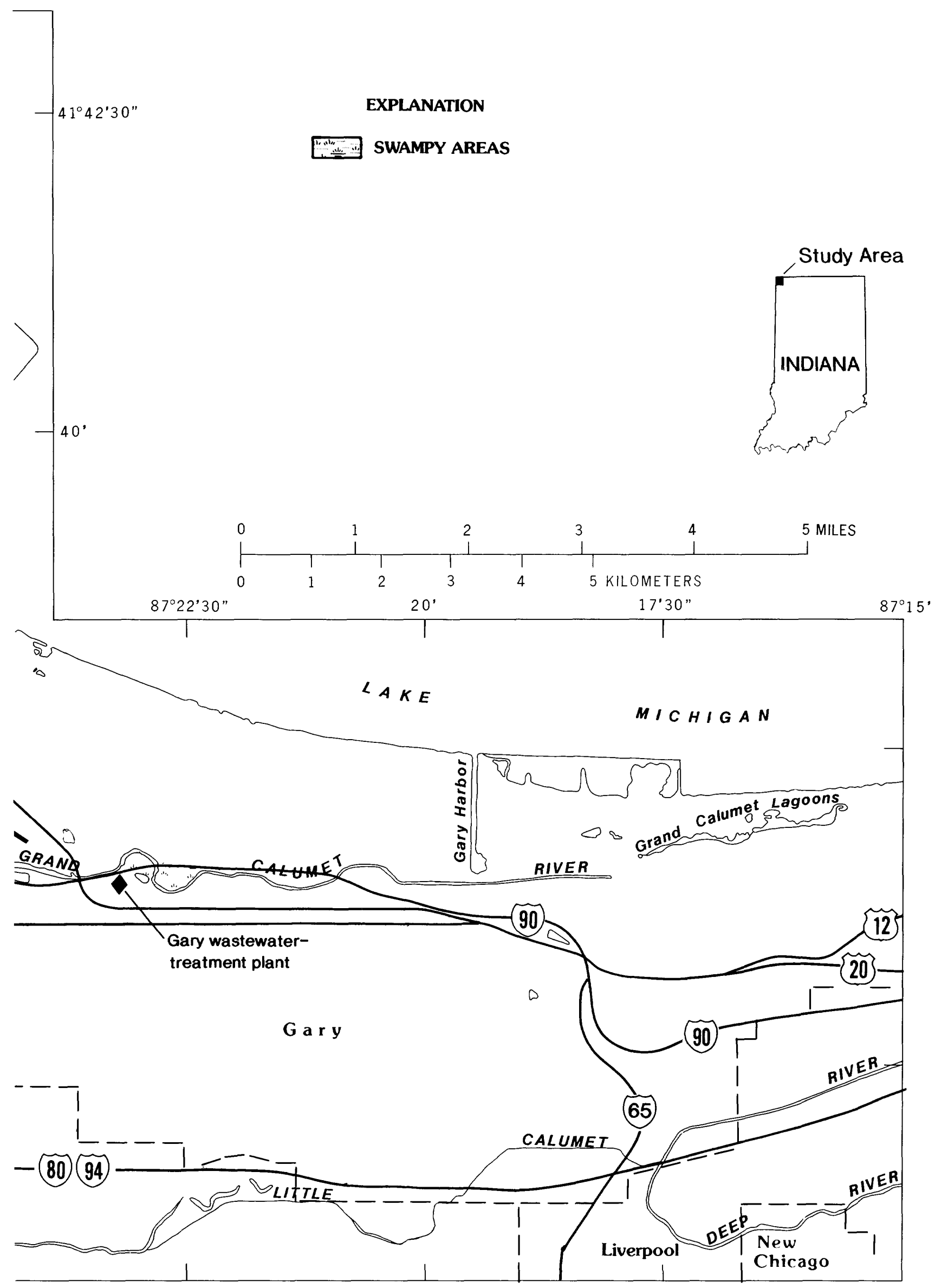

Hydrogeologic Setting of the Calumet Aquifer 5 


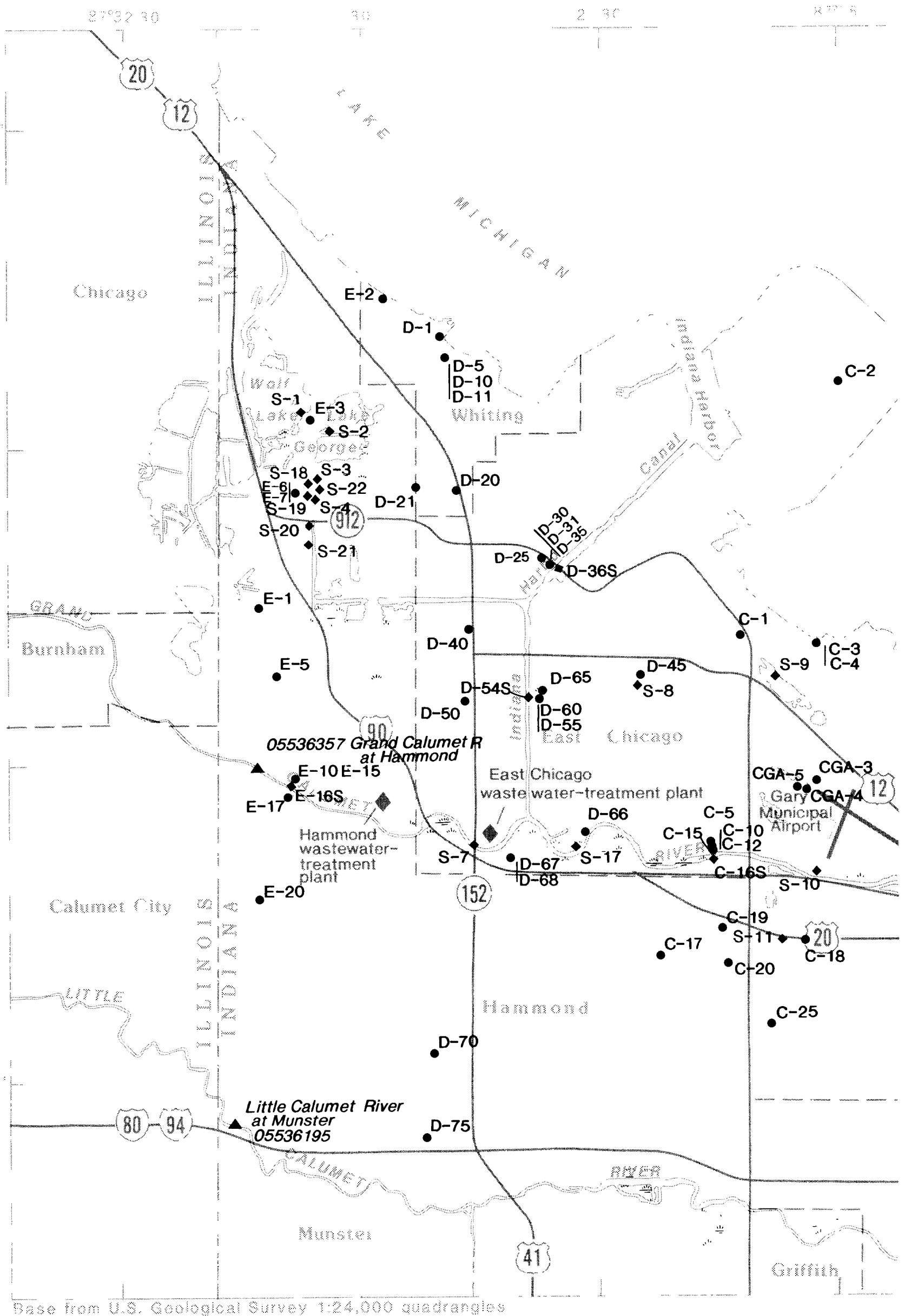

Figure 2. Locations of wells and surface-water sites, northern Lake County, Indiana. 


\section{EXPLANATION}

SWAMPY AREAS

- WELL USED FOR GROUND-WATER MEASUREMENT

- SURFACE-WATER-LEVEL MEASUREMENT SITE

A SURFACE-WATER-GAGING STATION
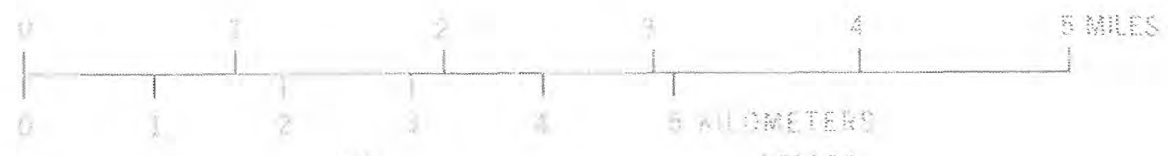

HWT 2-10, $P-11$

- HWT 14-5

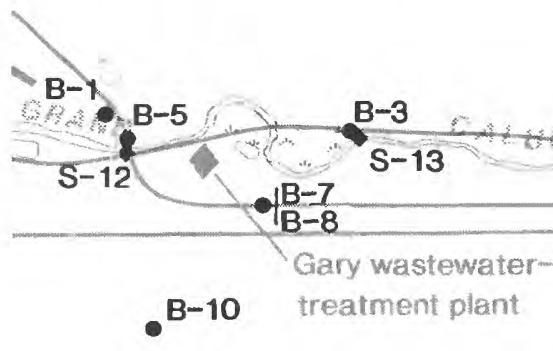

(a)
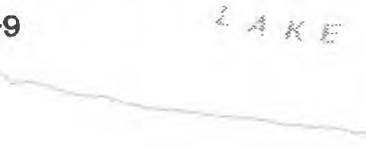

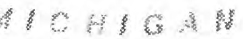

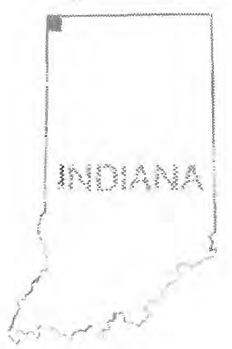

औitis

$1 \% 30$

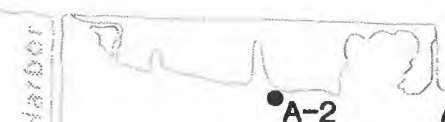

$\bullet A-2$

A-6.

$\infty \omega$

$0^{A-1}$

S-15
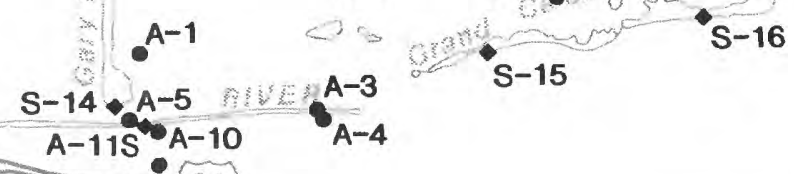

$A=15 \cdot 90$

$c^{B-10}$

teatment plant

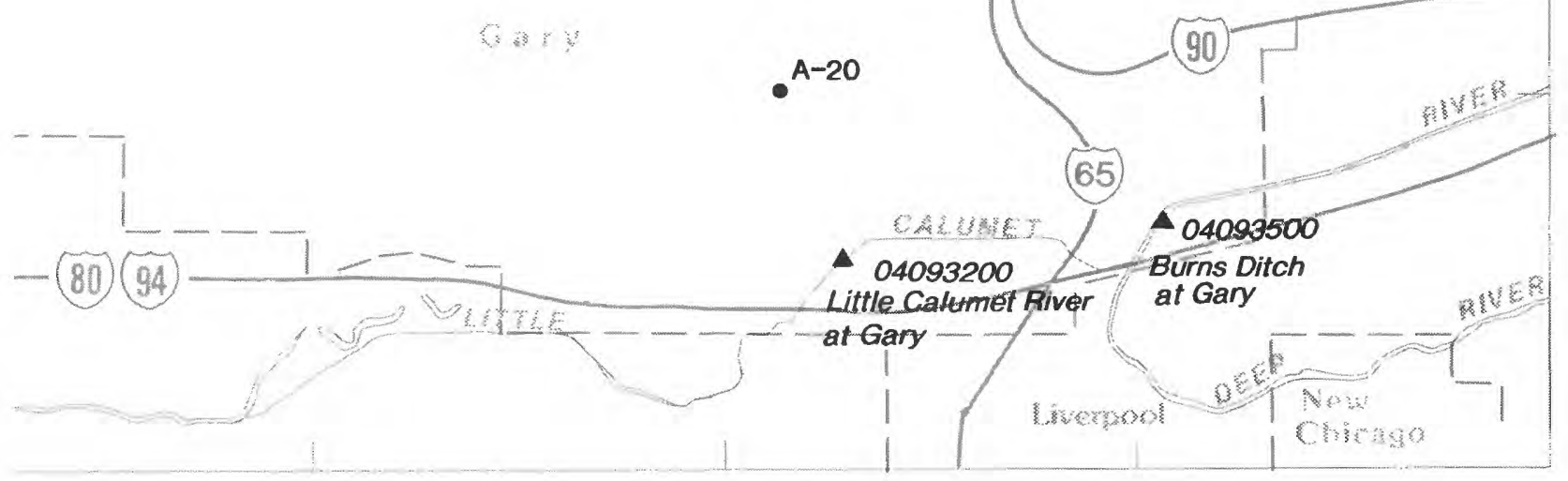




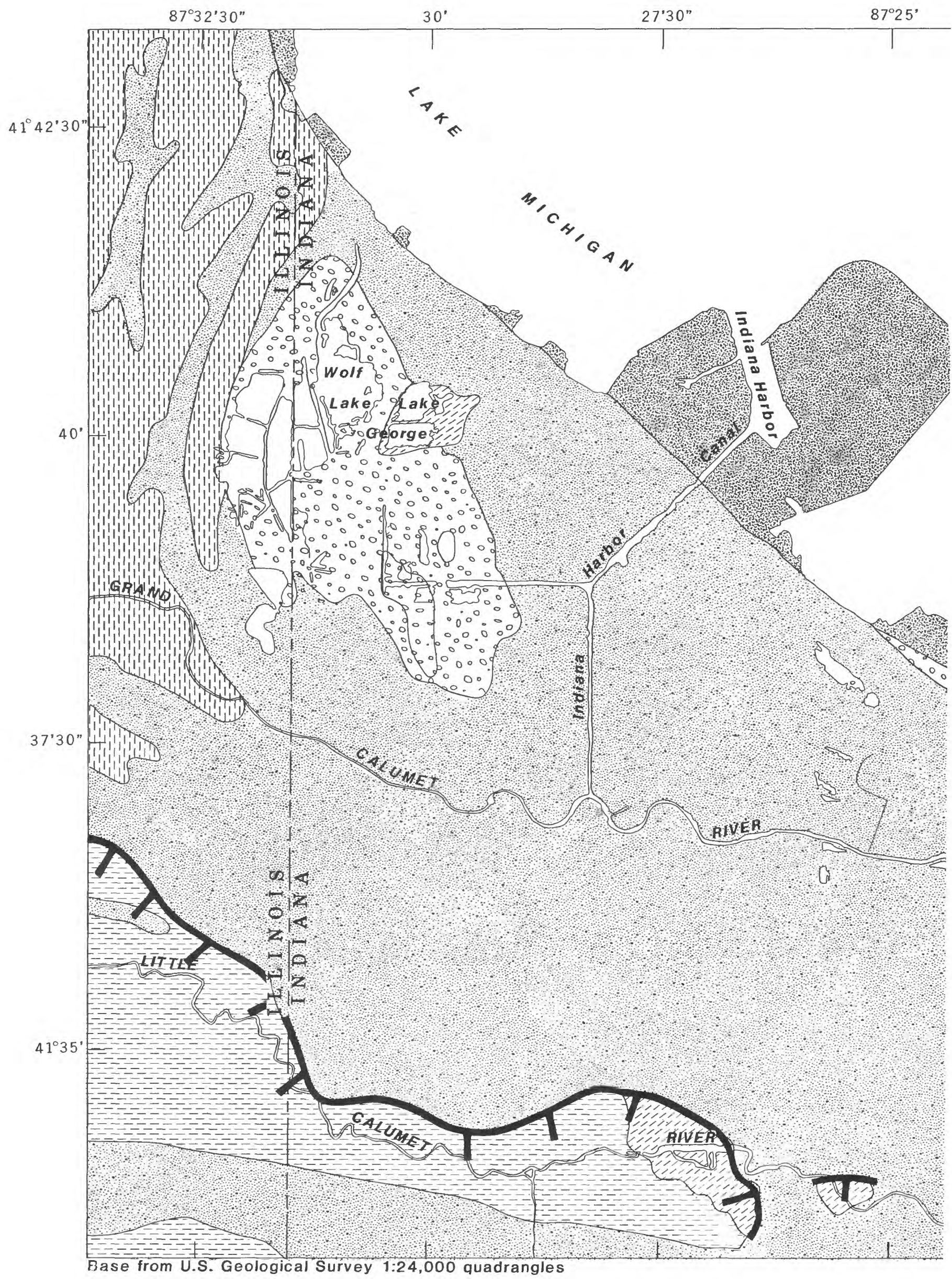

Figure 3. Surficial geology of the study area 
EXPLANATION

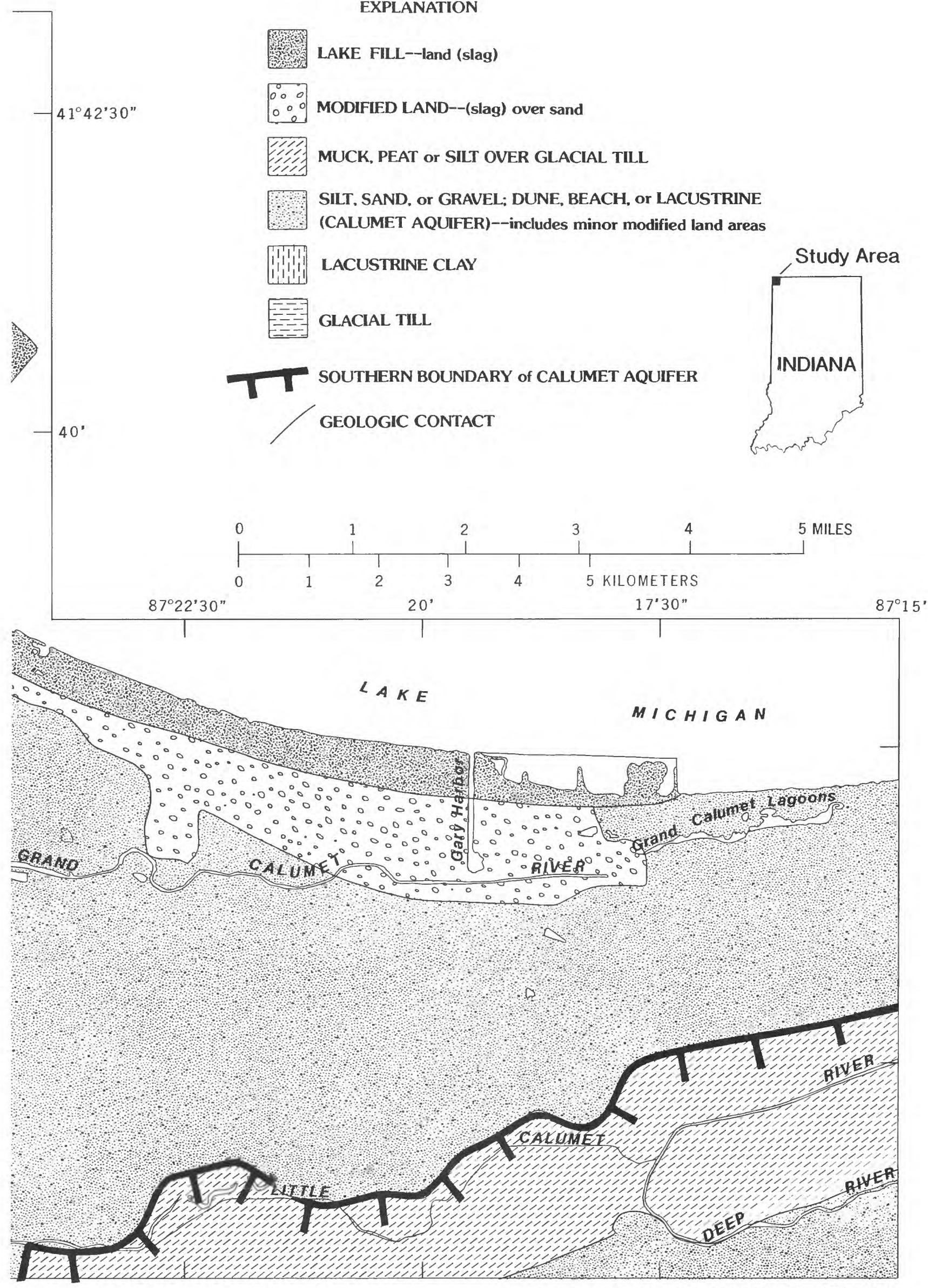

Geology modified from Schneider and Keller (1970. fig.B) 


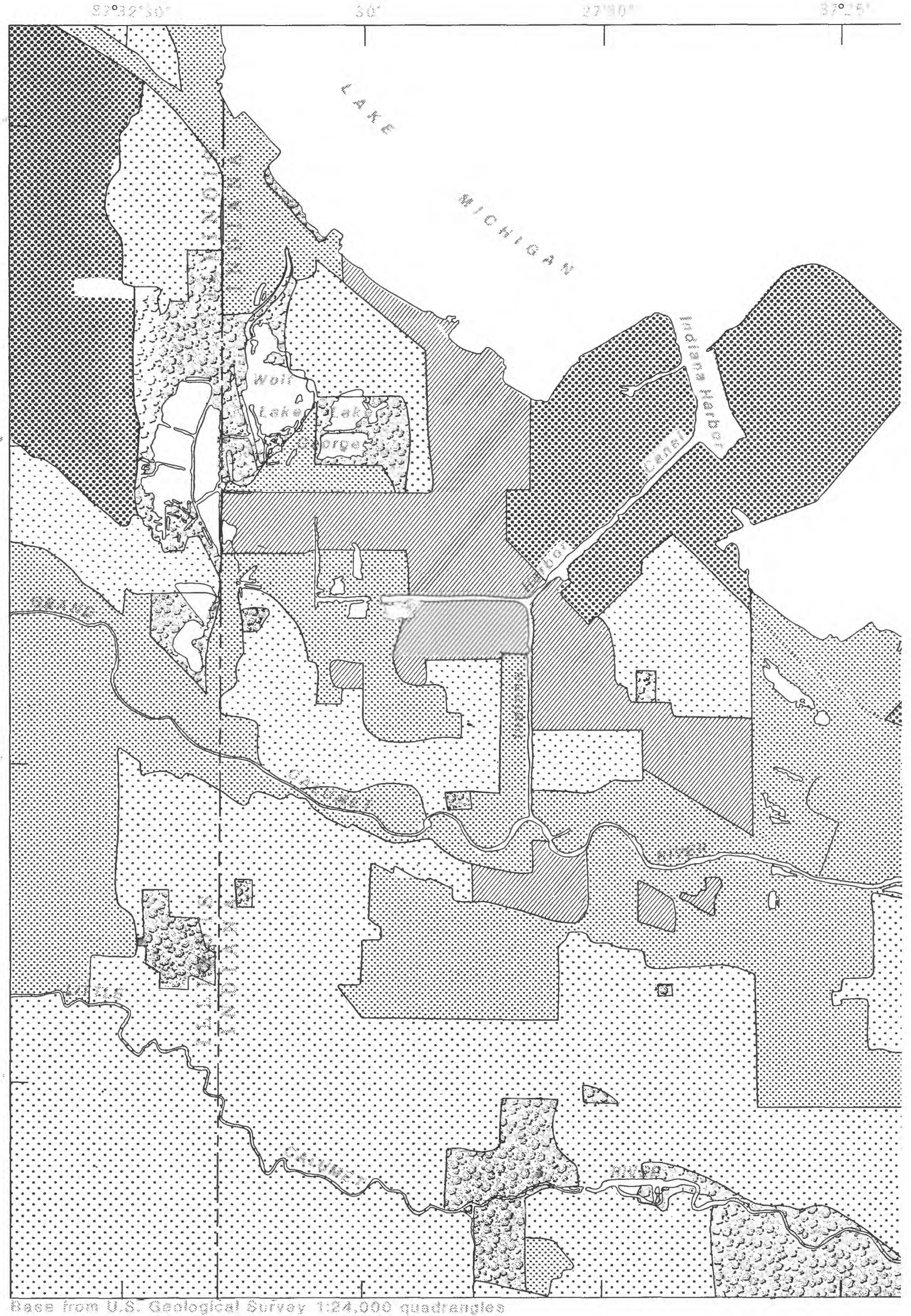

Figure 4. Major land uses in the study area. 


\section{EXPLANATION}

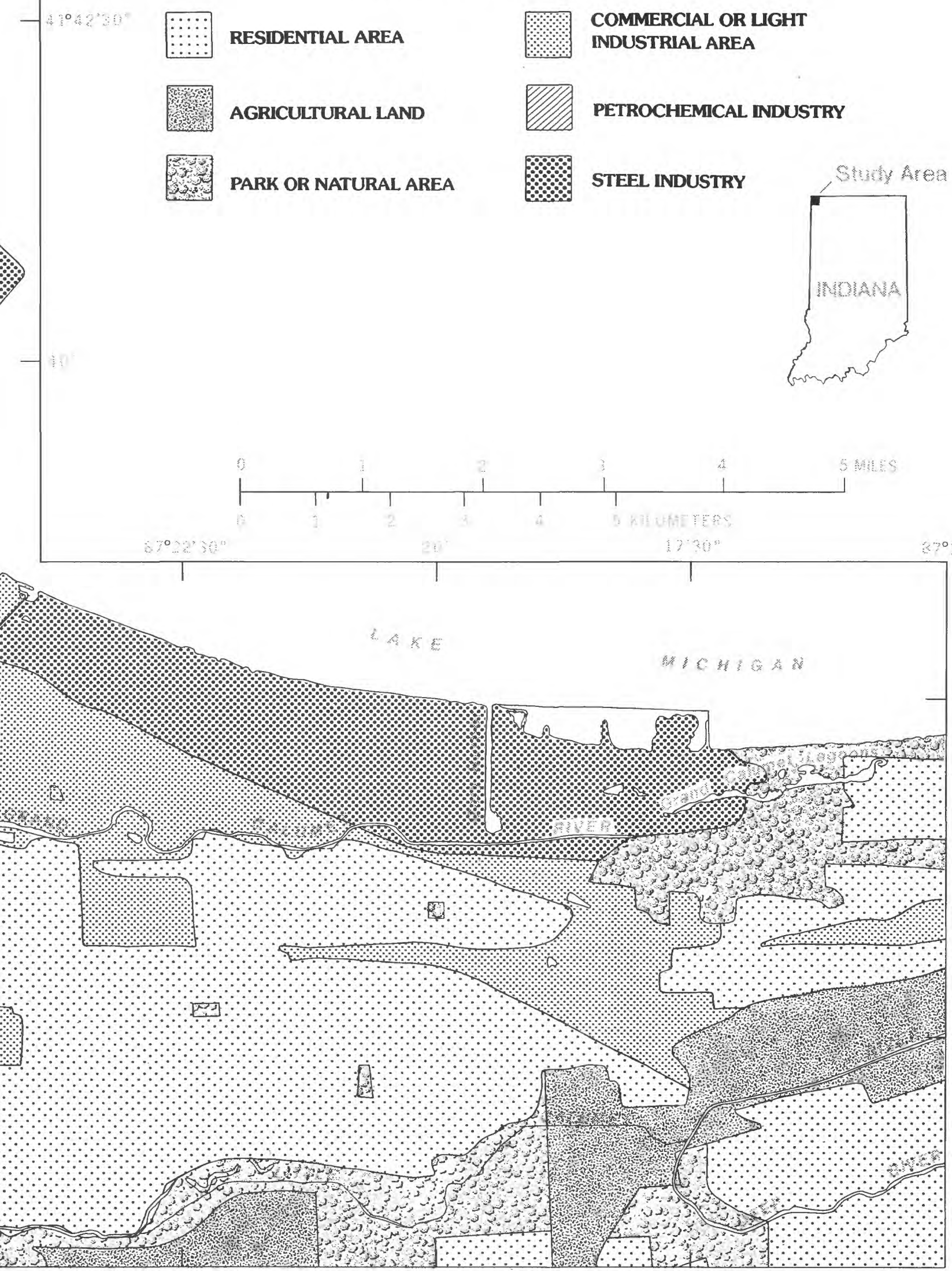


The Calumet aquifer is underlain by consolidated glacial till and lacustrine clay. Combined thickness of these deposits ranges from 50 to $130 \mathrm{ft}$ in the study area (unpublished data on file at the USGS office in Indianapolis). The horizontal hydraulic conductivity of the till ranges from 0.0003 to $0.0006 \mathrm{ft} / \mathrm{d}$ and the vertical hydraulic conductivity of the till ranges from and 0.003 to $0.0002 \mathrm{ft} / \mathrm{d}$ (Fenelon and Watson, 1993, p. 18). The lacustrine clay separates the Calumet aquifer from the underlying carbonate-rock aquifer of Silurian and Devonian age. The carbonate-rock aquifer is composed of limestone and dolomite. The carbonate-rock aquifer is 300 - to $400-\mathrm{ft}$ thick and underlies the entire study area. The Silurian and Devonian carbonate-rock aquifer is little used as a water source in this area because most water is supplied by Lake Michigan.

\section{Acknowledgments}

The USGS acknowledges the assistance of the many Federal, State, municipal, and corporate entities who helped make this report possible:

American Oil Company, Whiting, Ind.

E.I. DuPont DeNemours \& Co., East Chicago, Ind.

East Chicago, Ind., Parks Department

East Chicago, Ind., Public Schools

Gary, Ind., Airport Authority

Gary, Ind., Parks Department

Gary, Ind., Public Schools

Gary, Ind., Street Department

Hammond, Ind., Parks Department

Hammond, Ind., Public Schools

Indiana Department of Highways

Indiana Department of Natural Resources, Division of Nature Preserves

Indiana Toll Road Commission

Inland Steel Company, East Chicago, Ind.

Lake County Parks and Recreation

Lehigh Portland Cement Company, Gary, Ind.
National Park Service

Indiana Dunes National Lakeshore

Northern Indiana Public Service Company, Merrillville, Ind.

Phillips Pipeline Co., East Chicago, Ind.

U.S. Environmental Protection Agency, Region V

U.S. Steel (USX Corporation), Gary, Ind.

Whiting, Ind., Parks Department

Whiting, Ind., Public Schools

Whiting, Ind., Street Department

\section{DATA-COLLECTION NETWORK}

The data-collection network used by the USGS consisted of 70 observation wells and 30 surface-water sites in northern Lake County, Ind. (fig. 2). Measurement of the complete network took an average of 4 days. Measurements commonly began in the west and moved eastward through completion. Because of the need to schedule visits, wells on U.S. Steel (USX Corporation) property are commonly measured on day 2 of the field trip, and the USGS well on Inland Steel Company property was measured on day 3 .

\section{Ground-Water-Level Sites}

During the summer and fall of 1985,36 handdriven observation wells were installed. The wells were constructed of 2-in.-inside-diameter, Type 304 stainless-steel pipe. The wells have 3-ft-long Type 304 stainless-steel screens with 0.006-in. continuous-slot, wire-wound openings and a drive point at the base. Screens were set just below the ground-water surface. In 1987, five more hand-driven observation wells of similar construction were installed.

Well C-17 was installed in 1986 in the Gibson Woods Nature Preserve, 1.2 mi southeast of the junction of the Indiana Harbor Canal and the Grand Calumet River (fig. 2). Well C-17 also is known as Lake County well \#13 (LK-13) in the statewide observation-well network. Well C-17 
is constructed of 6-in.-inside-diameter polyvinyl chloride (PVC) casing and a 5-ft-long PVC screen with 0.008 -in. continuous-slot, PVC-wound opening. The well has a total depth of $23 \mathrm{ft}$, and the screen begins about $10 \mathrm{ft}$ below the ground-water surface. Daily-mean water-level data for this well (reported as site \#413559087270301, Lake County \#13, LK-13) have been published in the annual USGS water resources data report for Indiana since 1986.

In 1987, 18 observation wells were drilled with a hollow-stem auger drill rig. The drilled wells were constructed of 2 -in.-inside-diameter, Type 316L stainless-steel pipe, and have 5-ft-long Type $316 \mathrm{~L}$ stainless-steel screens with 0.006 -in. continuous-slot, wire-wound openings. These wells have a hollow, 2-ft-long blank stainless-steel casing below the screen, and total depth of these wells includes the $2.0 \mathrm{ft}$ below the screen. Screens for most of the drilled wells were set near the middle of the Calumet aquifer.

Wells at 7 sites were paired and screened at different depths in the Calumet aquifer. Waterlevel data collected at the paired-well sites provide information on the vertical-flow gradients in the Calumet aquifer. An additional 10 non-USGS wells used in the observation-well network were installed before 1985 by means of numerous construction methods and materials (table 1).

\section{Surface-Water-Level Sites}

There are 30 surface-water sites in the waterlevel network monitored by the USGS (table 2). These include 1 Lake Michigan site, 3 inland-lake sites, 10 ditch sites, 1 sewer-measurement site, 2 Indiana Harbor Canal sites, 9 Grand Calumet River sites, 2 Calumet Lagoon sites, and 2 Little Calumet River sites (fig.2).

Six surface-water sites in the network are paired with two to four shallow wells. The wells were installed to form transects perpendicular to the Grand Calumet River or the Indiana Harbor
Canal. These transects were designed to allow analysis of ground-water/surface-water interactions. The surface-water sites paired with wells are A-11S, C-16S, D-36S, D-54S, E-16S, and S-12.

An additional Lake Michigan site (S-23) has been included among the data reported here (table 2). Site S-23 is an hourly lake-level gage operated by the National Oceanic and Atmospheric Administration (NOAA) at Calumet Harbor, Ill. The NOAA gage, station 908-7044, is at latitude $41^{\circ} 43^{\prime} 48^{\prime \prime} \mathrm{N}$; longitude $87^{\circ} 32^{\prime} 18^{\prime \prime} \mathrm{W}, 1.75 \mathrm{mi}$ northwest of the study area. In general, one lake level per month is reported for site S-23 (tables 2 and 5). Lake levels for site S-23 are daily means of the hourly NOAA data. Measurement dates either correspond to the date when USGS site S-14 was measured or to the middle date of each month.

\section{GROUND-WATER LEVELS AND THEIR RELATION TO SURFACE-WATER LEVELS}

Summary statistics of the ground-water and surface-water data were computed (tables 3 and 4). Data presented for the data sets are the following: number of measurements, mean value, median value, standard deviation, minimum value, maximum value, and beginning and ending dates. Surface-water sites S-5 and S-6 are omitted from the data tables because the water-level data are unreliable.

Caution is advised in the comparison of sites with dissimilar numbers of measurements. The summary statistics are affected by the number of observations per site. If only a few measurements are made at a given site, then each measurement affects the summary statistics more than if more measurements had been made. Sites measured more than 45 times (C-17 and S-23) should not be compared with sites where the number of measurements was nearer to the overall average of 25 per site. The same is true of sites measured fewer than 15 times or less (C-18, D-65, CGA-5, S-3, S-4, S-7, S-16, S-17, S-18, S-19, S-20, S-21, S-22 and $D-54 S$ ) because they are not representative (table 5, at back of report). 


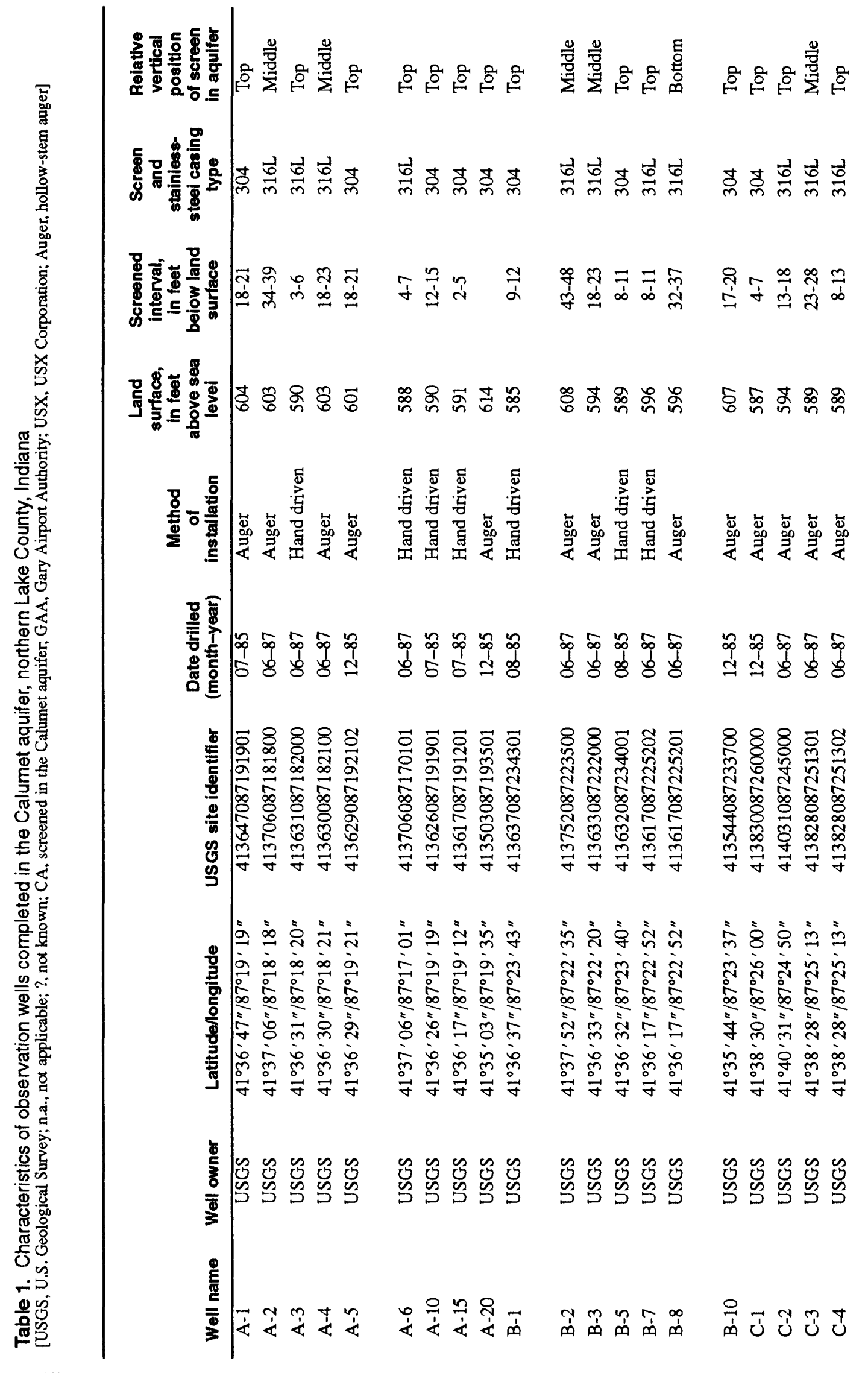

14 Water Levels in the Caiumet Aquifer 


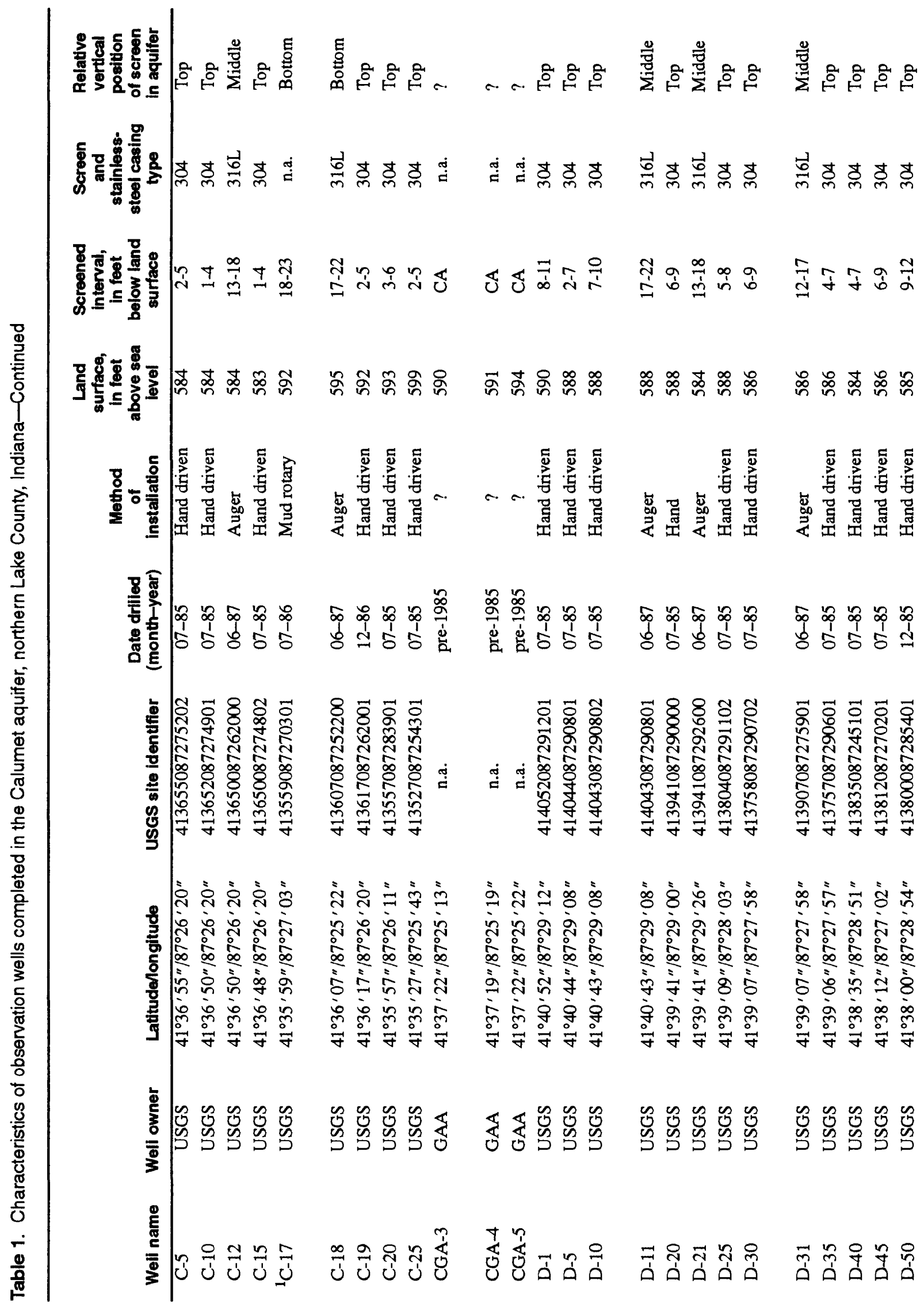




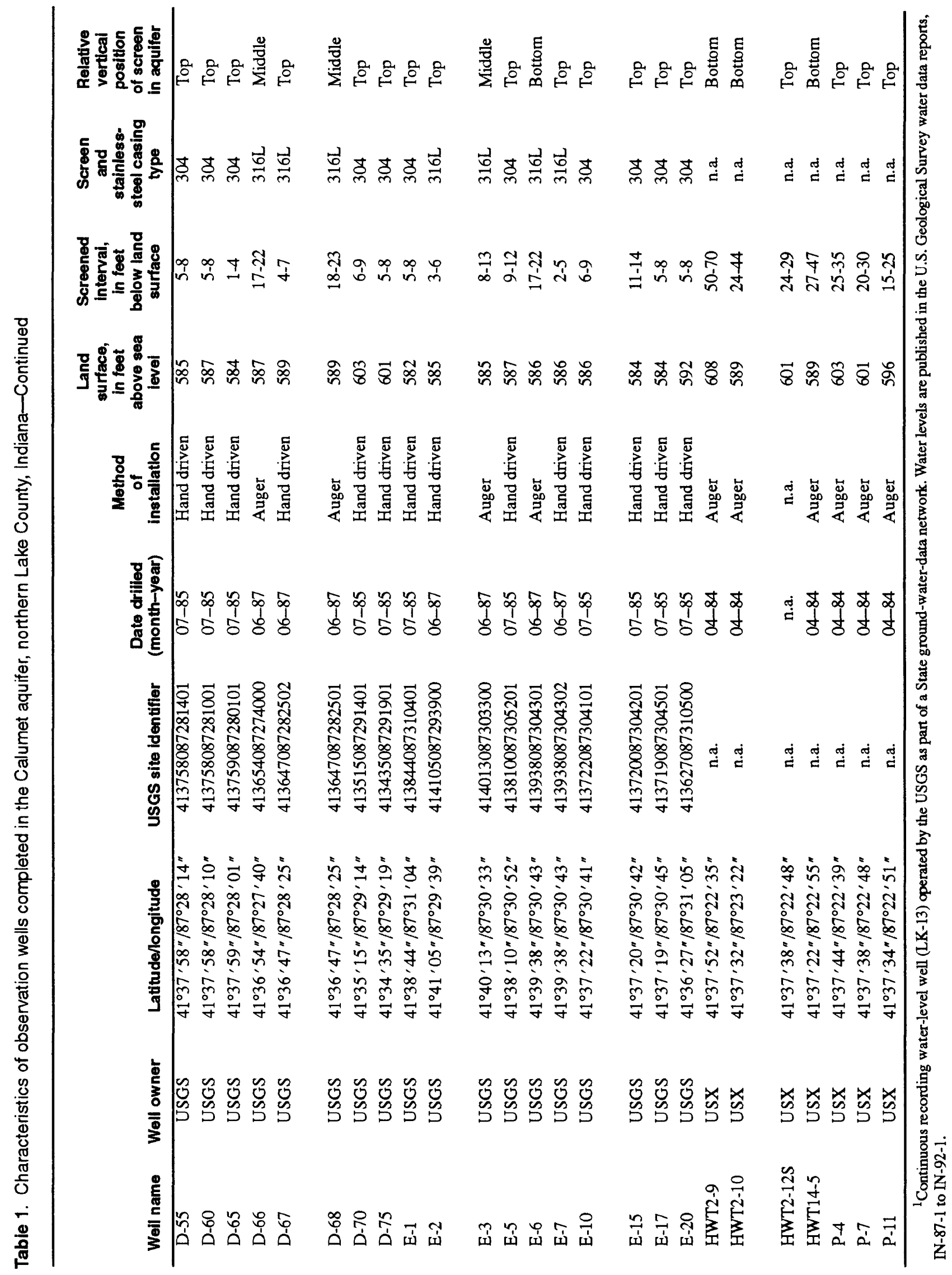




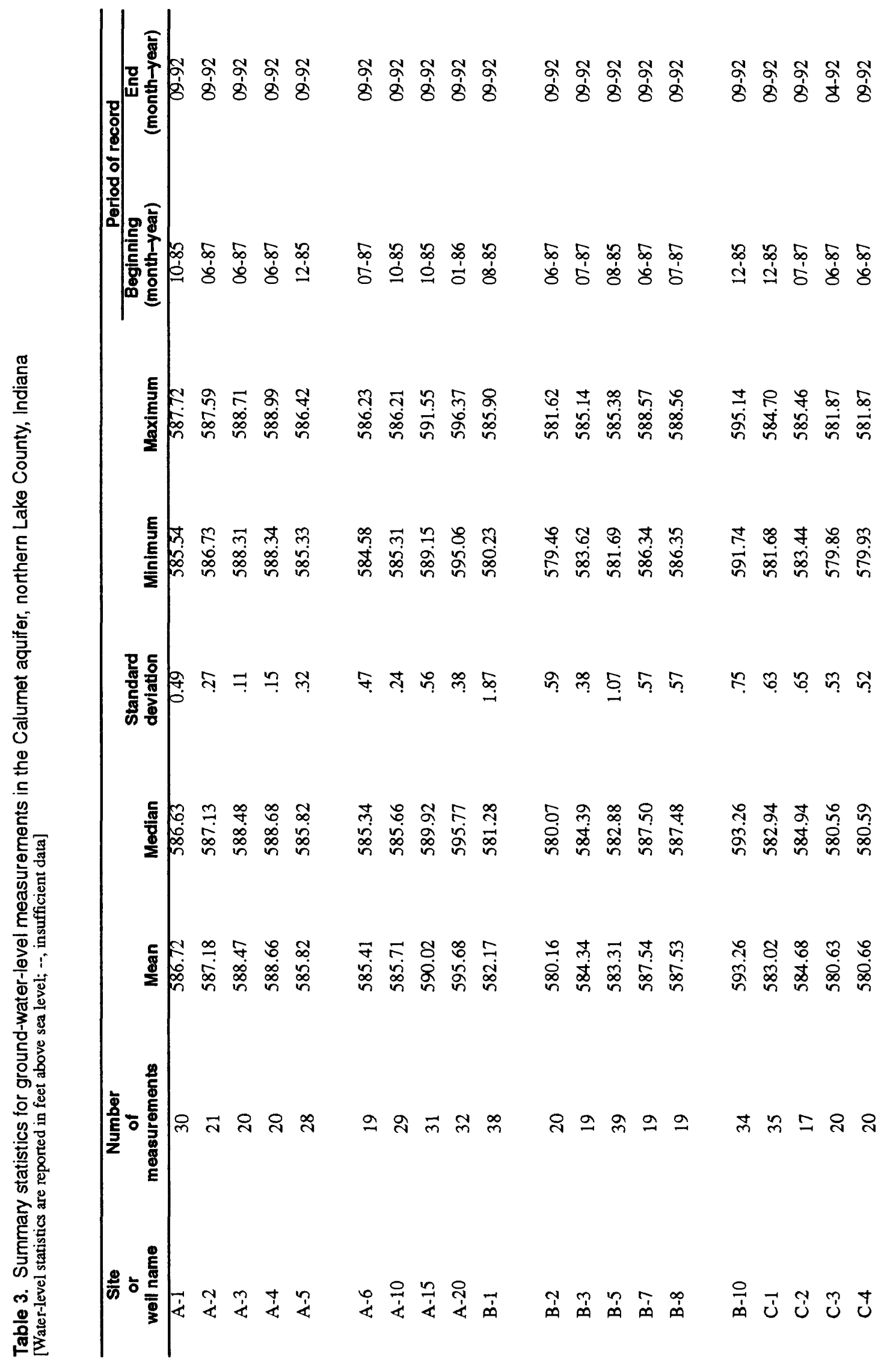




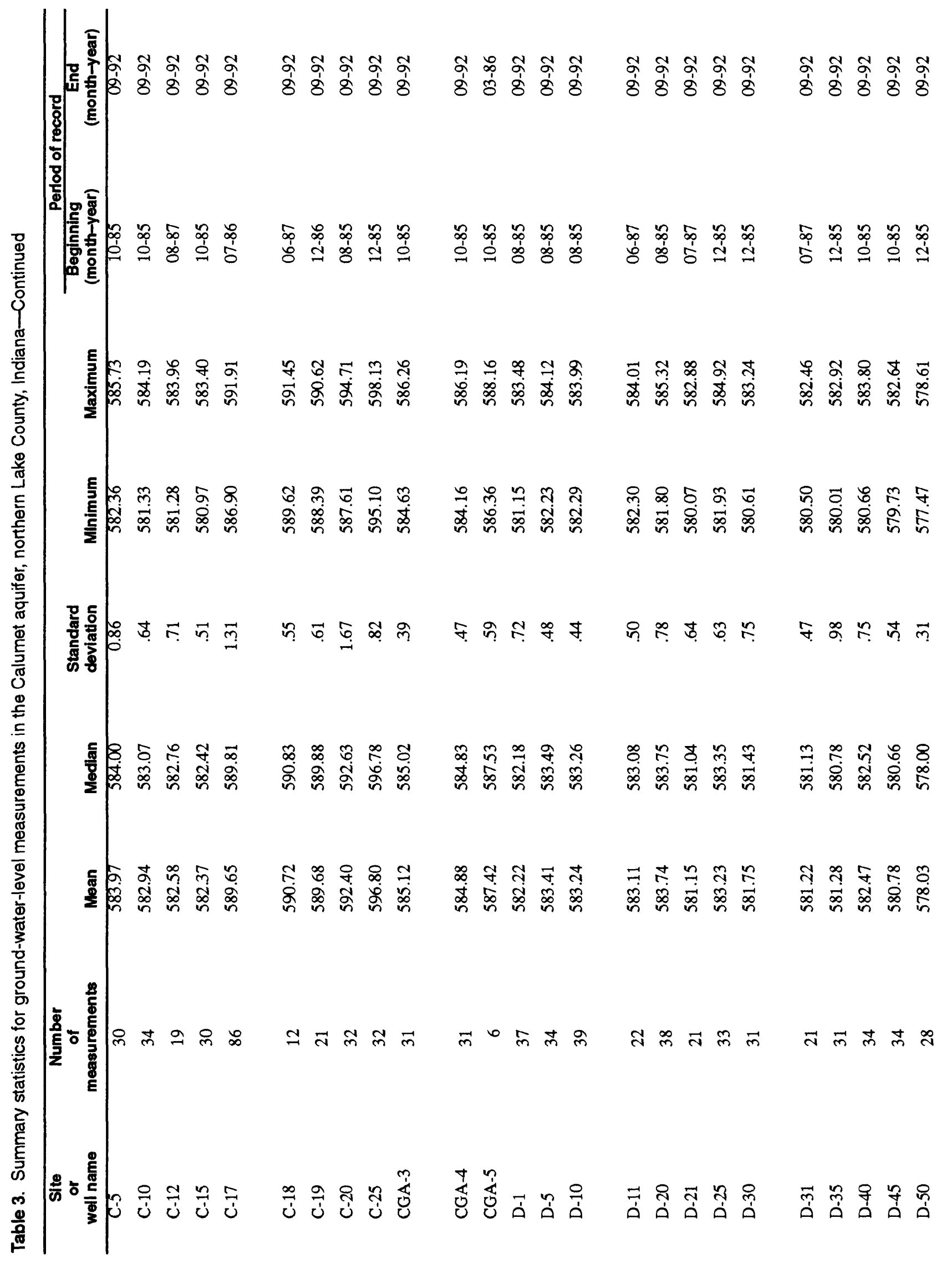




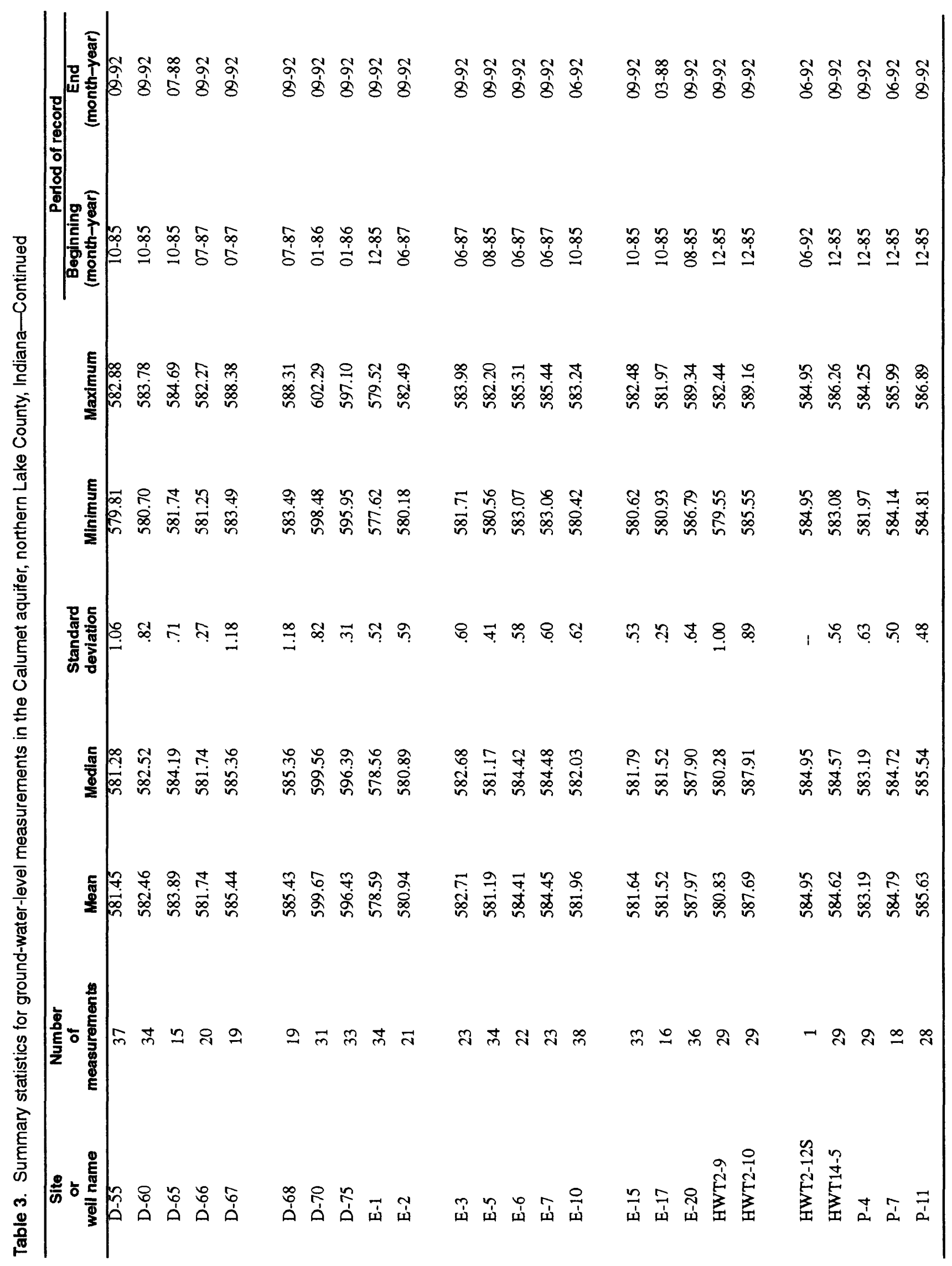




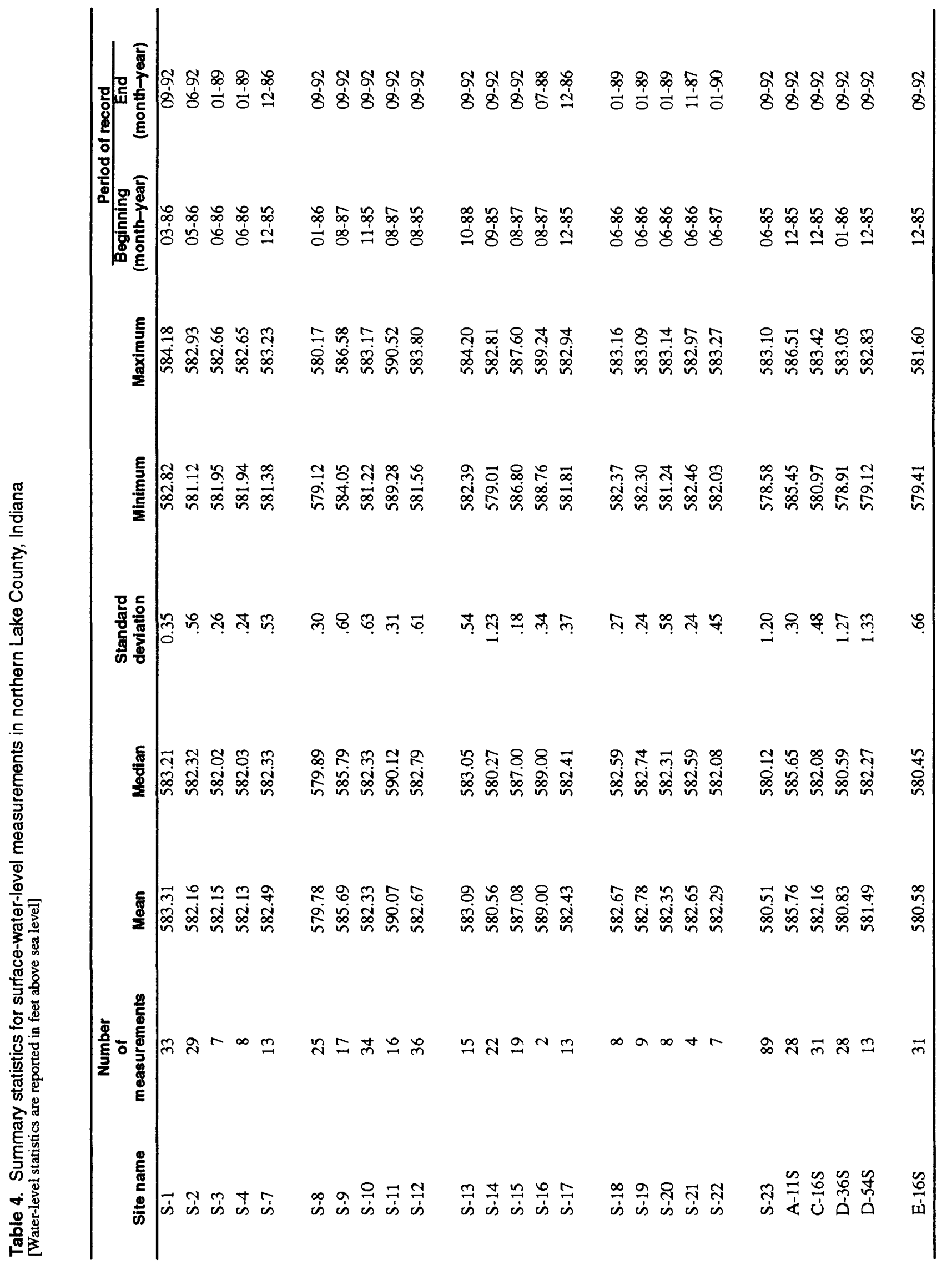




\section{Water-Level Fluctuations}

Ground-water levels in the USGS datacollection network commonly reached an annual maximum in June or July, the months of maximum precipitation (National Oceanic and Atmospheric Administration, 1982). Another peak in groundwater levels during February and March of most years was related to the spring thaw. Annual minimum ground-water levels commonly occurred in September or October, although the minimum has occurred earlier and later within the data set. The effects of evapotranspiration can be seen in hourly ground-water-level data collected at well C-17 (also called LK-13). During the day, water is absorbed by the plant roots and transpired into the atmosphere from the leaves. The hydrograph in figure 5 shows how this activity lowers the water level several hundredths of a foot each day. At night, the plant activity stops, and water levels rebound somewhat.

Analysis of USGS ground-water-level data, collected from August 1985 through September 1992 (table 5, at back of report), indicates that ground-water fluctuations (total difference between highest and lowest water levels measured) in the Calumet aquifer ranged from a minimum of $0.40 \mathrm{ft}$ at well A-3 to a maximum of $5.01 \mathrm{ft}$ at well C-17. The mean ground-water fluctuation measured in the study area was about $2.3 \mathrm{ft}$. Although the water levels in two wells (B-1 and C-20) fluctuated more than $5.50 \mathrm{ft}$, the lowest water levels at both wells were affected temporarily by nearby dewatering projects.

Surface-water-level data collected during the same 7-year period indicate that surface-water fluctuations (total difference between highest and lowest water levels measured) were greatest on Lake Michigan and on sites hydraulically connected to the lake. During the study period, the total fluctuation measured on Lake Michigan at USGS site S-14 (at the southern end of Gary Harbor) was $3.80 \mathrm{ft}$.
The greatest fluctuation in surface-water level within the USGS network data was $4.14 \mathrm{ft}$, measured at site D-36S on the Indiana Harbor Canal. Although site D-36S is about $2.5 \mathrm{mi}$ inland from the open water of Lake Michigan, the Indiana Harbor Canal is hydraulically connected to the lake. The measured surface-water fluctuation at another Indiana Harbor Canal site, D-54S, was $3.71 \mathrm{ft}$ during the data-collection period. Site $\mathrm{D}-54 \mathrm{~S}$ is $3.75 \mathrm{mi}$ inland from the lake; however, water levels are nearly equivalent to lake level. Wind and ship traffic in the Indiana Harbor Canal can cause rapid changes in the surface-water level. Although site D-54S is upstream from the navigational limit of ship traffic, the site still may be affected by that traffic. Measurements were not attempted when boats were passing.

The water-level fluctuation in Lake Michigan was slightly greater at the NOAA site S-23 (Calumet Harbor, Ill.) than at the USGS Lake Michigan site S-14. Mean daily water levels for site S-23 indicate that lake levels fluctuated $4.52 \mathrm{ft}$ from August 1985 through September 1992. The larger fluctuation at site S-23 is due partly to the greater number of measurements (89) than the number of measurements (22) at site S-14 (table 3).

Analysis of the USGS surface-water data collected from August 1985 through September 1992 indicates that, overall, fluctuations were the greatest at the downstream sites on the east branch of the Grand Calumet River. These sites, however, are influenced by backwater effects when the level of Lake Michigan is high. Of the eight sites on the Grand Calumet River (east and west branches), only the most upstream site on the east branch (A-11S) was unaffected by backwater from Lake Michigan. Stage fluctuations on the east branch of the Grand Calumet River also are influenced by continuous industrial outfalls and the Gary wastewater-treatment facility, which is $1,000 \mathrm{ft}$ upstream from site S-12 (Crawford and Wangsness, 1987, p. 32). Stage fluctuations at the two west branch Grand Calumet River sites also are affected by discharges from the East Chicago and Hammond wastewater-treatment facilities (Crawford and Wangsness, 1987, p. 35). 


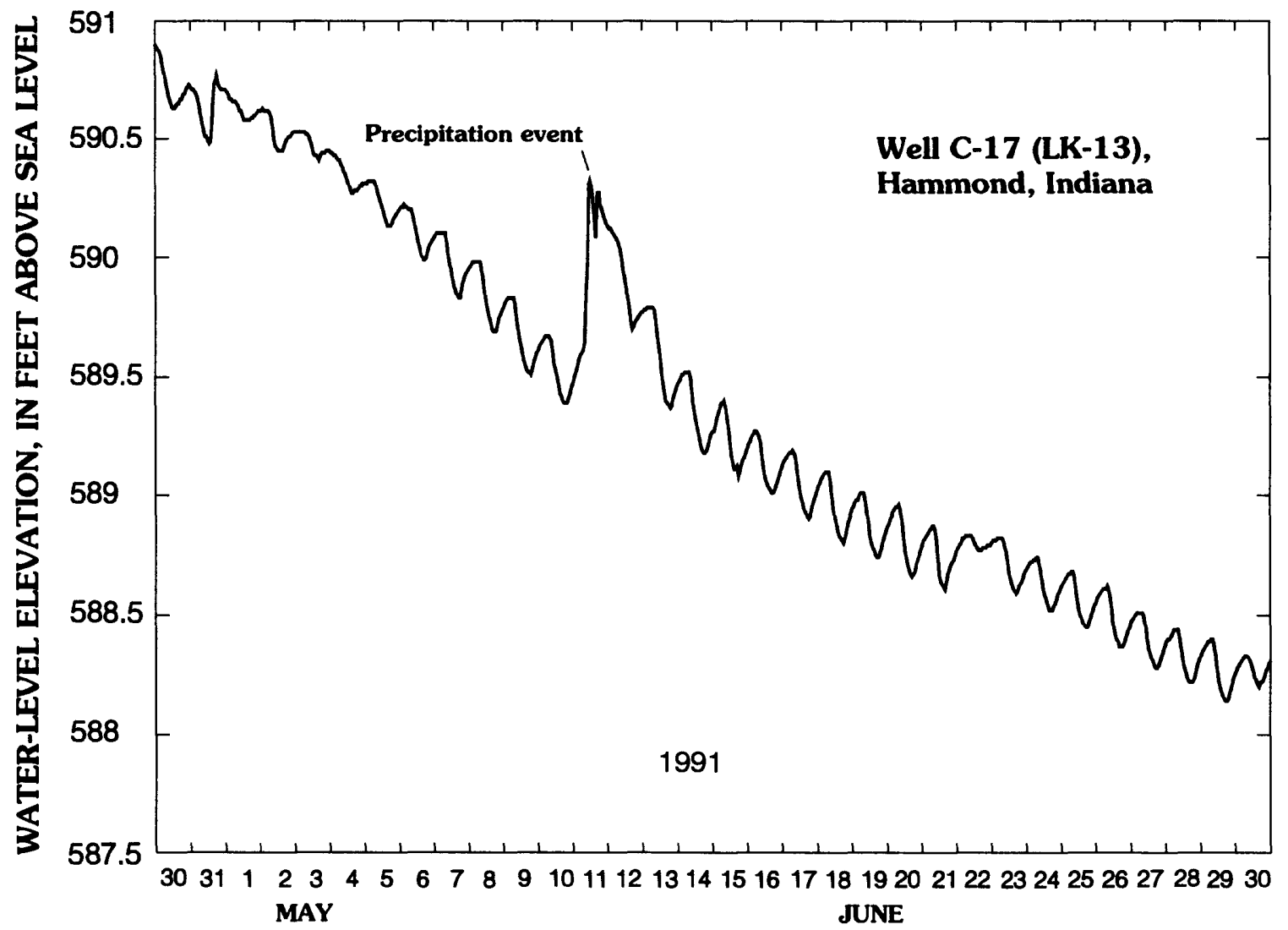

Figure 5. Ground-water hydrograph showing the daily effects of evapotranspiration.

Stage fluctuations at the six sites on the east branch of the Grand Calumet River (A-11S, C-16S, S-10, S-12, S-13, and S-17) ranged from 1.06 to $2.45 \mathrm{ft}$ during the study period. Stage fluctuations at the two sites on the west branch of the Grand Calumet River (S-7 and E-16S) ranged from 1.85 to $2.19 \mathrm{ft}$ during the study period.

The low magnitude of the fluctuations in the Grand Calumet River is a result of several circumstances:

1. Most of the flow in the river is industrial or municipal effluent, discharged at a fairly constant rate.

2. The relief of the basin is low (highest point is only $50 \mathrm{ft}$ above Lake Michigan).
3. Precipitation infiltrates directly into the Calumet aquifer.

4. The Grand Calumet River is hydraulically connected to the Calumet aquifer system, and response in one is seen in the other.

5. The hydraulic conductivity of the aquifer stabilizes the rate of discharge to the surface water.

The stability of the aquifer is such, that unless a major recharge event occurs during data collection (such as the 3.00-in. rainfall on November 27, 1990, which raised ground-water levels more than $1.0 \mathrm{ft}$ in well $\mathrm{C}$-17), ground-water levels should vary less than $0.2 \mathrm{ft}$ in a 4-day data-collection period. Thus, the data within 
most sets can be used as if they were collected simultaneously. Variation at sites affected by evapotranspiration can be as much as $0.4 \mathrm{ft}$ in 4 days, however. The levels of Lake Michigan can vary significantly over short periods, and hourly lake-level data may be necessary to determine whether surface-water levels in the Indiana Harbor Canal and the Grand Calumet River were affected.

\section{Changes Induced by Drought}

Below-average precipitation was reported throughout Indiana from October 1987 through September 1988. The below-average precipitation allowed ground-water levels in most areas of the State to decline to record lows (Fowler, 1992, p. 30). Although northwestem Indiana was especially hard hit, water levels in the Calumet aquifer were not significantly affected by the drought of 1988 . Only 40 percent of the network wells registered record low water levels during the drought. Record low water levels were reported for wells A-5, A-6, B-1, B-5, C-1, C-5, C-10, C-12, C-15, C-18, C-19, C-25, CGA-3, D-20, D-60, D-65, D-67, D-68, D-70, E-1, E-3, E-6, E-7, E-10, E-20, P-4, P-7, and P-11 (fig. 2).

During the drought of 1988 , the deficit in precipitation coincided with reversals of normal vertical flow gradients in many areas of the Calumet aquifer. This reversal was observed in most sets of paired deep and shallow wells. Water levels in two sets of paired wells (deeplshallow), D-11ID-10, and D-31ID-30, best illustrate the reversal of normally upward flow gradients (figs. 6A and 6B). Water levels at paired well site E-6|E-7 best illustrate the reversal of normally downward flow gradients during the drought of 1988 (fig. 6C). Water levels in D-68ID-67, another set of paired wells about $1,000 \mathrm{ft}$ from the Grand Calumet River, indicate that normally horizontal flow gradients were affected only slightly in 1988 (fig. 6D). Screen depths for these wells are listed in table 1. Vertical flow gradients in paired USGS wells in the Calumet aquifer generally are less than $0.15 \mathrm{ft}$. The lack of larger differences in vertical gradients indicates the moderate to high vertical hydraulic conductivity. Greater differences would indicate decreased vertical hydraulic conductivity within the aquifer because of silt and clay. During the study period, monthly precipitation ranged from 0.07 in. (February 1987) to $9.45 \mathrm{in}$. (August 1990), as recorded at Hobart, Ind., $6 \mathrm{mi}$ south of Lake Michigan and $2.5 \mathrm{mi}$ southeast of the study area (fig. 7).

Water levels in the remaining wells were lower at other times during the study period. More than 25 percent of the wells had record low water levels in 1992. Other years when several record low water levels were observed were 1986 and 1991. Explanations of why the drought of 1988 had such a small effect on water levels in the Calumet aquifer are conjecture. The most probable explanation, however, is that the Calumet aquifer is little used as a water supply and that the tremendous volume of water stored in the aquifer creates stability.

Record low water levels were observed at 11 surface-water sites during the drought of 1988 : S-1, S-2, S-3, S-4, S-9, S-16, S-18, S-19, S-20, C-16S, and E-16S. Eight of the affected surfacewater sites are in the Wolf Lake and Lake George area and near the Indiana-Illinois State line (fig. 2). The three other surface-water sites are east of the Indiana Harbor Canal. The effect of the drought of 1988 on Lake Michigan levels is unclear. Lake levels (Calumet Harbor gage) rose about $1.0 \mathrm{ft}$ during the first 5 months of 1988 before declining during the remainder of the year (Jeff Oyler, National Oceanic and Atmospheric Administration, written commun., 1992).

\section{Changes Induced by Lake Michigan}

Lake Michigan was at record high levels from fall 1985 through summer 1986 (fig. 8). Historical maximum monthly-mean lake levels were established each month during this period. The maximum daily-mean lake level at Calumet Harbor, Ill., was $583.50 \mathrm{ft}$ on October 25, 1986 (Jeff Oyler, National Oceanic and Atmospheric Administration, written commun., 1992). Since 1986, the level of Lake Michigan has dropped to slightly below the normal pool level of $580 \mathrm{ft}$. The minimum daily-mean lake level during the 

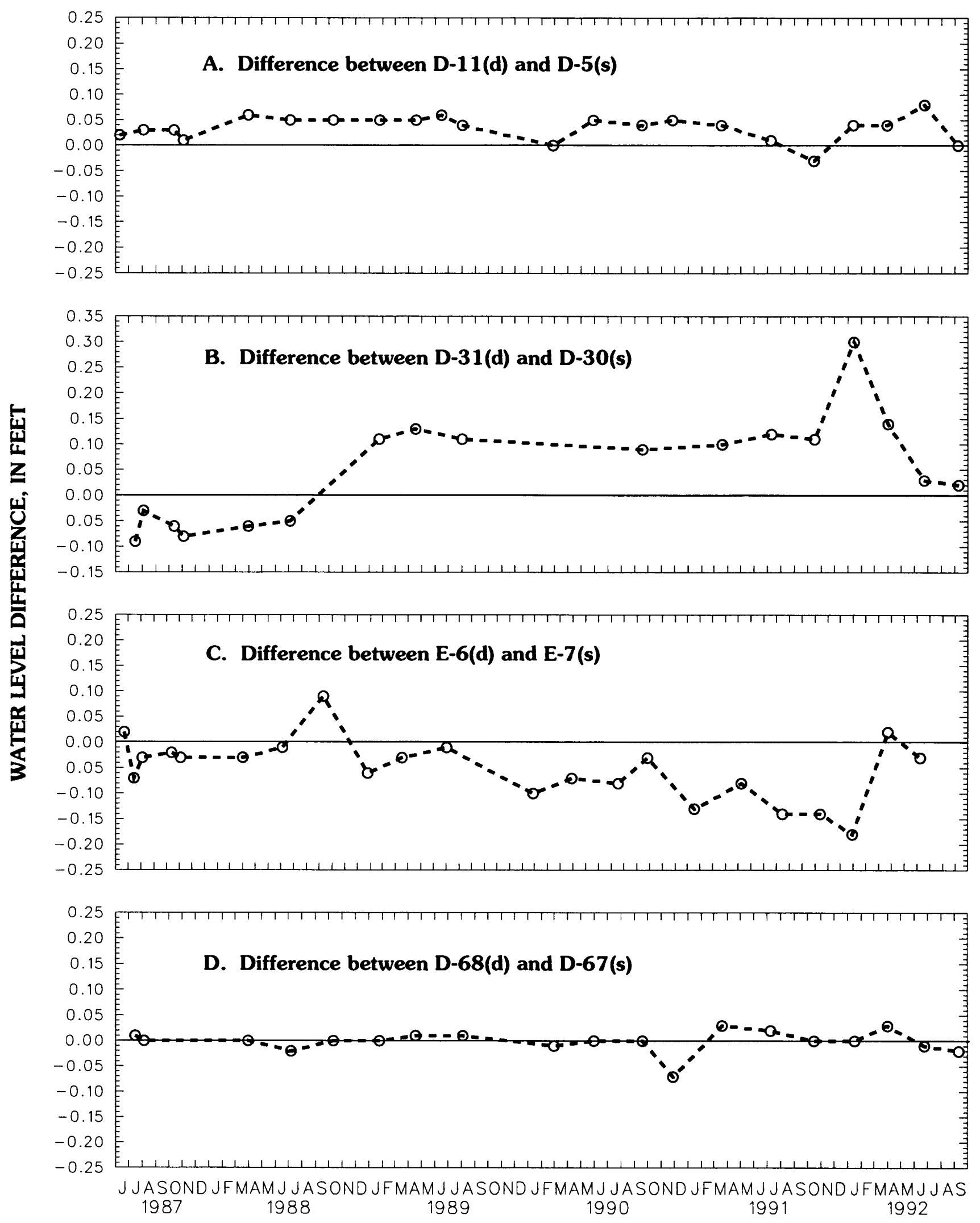

Figure 6. Difference in water levels between deep (d) and shallow (s) wells, northern Lake County, Indiana. (Differences greater than zero indicate upward vertical flow.

Differences less than zero indicate downward vertical flow.) 


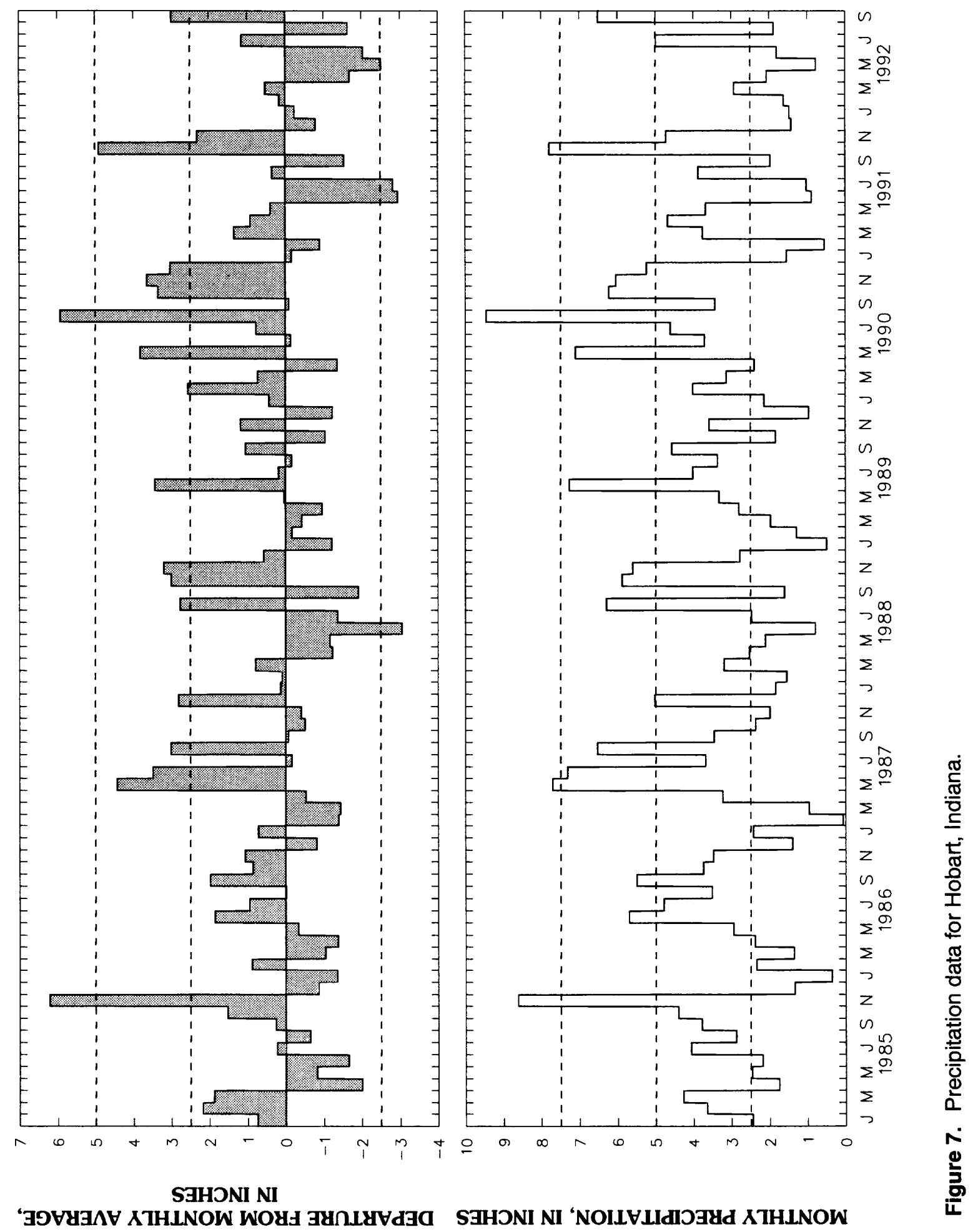


study period was $578.05 \mathrm{ft}$ on January 2, 1990 (Jeff Oyler, National Oceanic and Atmospheric Administration, written commun., 1992).

The high levels of Lake Michigan during 1985-87 created long-term backwater effects on the east branch of the Grand Calumet River. Backwater effects on the east branch are interpreted in the data as far upstream as site S-13, about 11.0 mi upstream from Lake Michigan (fig. 2). The rise in Lake Michigan decreased the surface-water gradient and the velocity of the east branch of the Grand Calumet River.

Similarly, the surface water is the base level of the water table. When the base level (surface water) of the ground-water system rises, the water-table slope decreases, thus reducing groundwater velocity and discharge. In this way, a prolonged rise in Lake Michigan level can result in a rise in ground-water levels, especially near backwater areas. The distance away from a stream where the ground water will rise depends on the length of time that the lake is high. If the lake level remained high indefinitely, the ground water would reestablish the previous slope at the higher level. USGS network data do not indicate a basinwide rise in ground-water levels in response to high lake levels during 1985-87. This is probably because sewers and ditches drain large areas of the basin.

West of the Indiana Harbor Canal diversion, backwater effects on the west branch of the Grand Calumet River were observed as far west as the East-West Toll Road (Interstate 90) bridge. The west branch of the Grand Calumet River, however, is very different from the east branch. Before the diversion was built, the Grand Calumet River was not connected to Lake Michigan through the Indiana Harbor Canal. When the level of Lake Michigan is below approximately $582.00 \mathrm{ft}$, a surface-water divide develops in the west branch of the Grand Calumet River in the swampy area near the East-West Toll Road bridge (figs. 11 and 12). East of the swampy area, when the lake level is below $582.00 \mathrm{ft}$., flow is eastward toward the Indiana Harbor Canal diversion and Lake Michigan. West of the Toll Road, flow is consistently westward into Illinois. This drainage divide shifts east and west in response to changes in
Lake Michigan level, discharge of industrial and municipal effluent to the river, storm runoff, and wind direction and velocity (Crawford, 1987, p. 3; Fenelon and Watson, 1993, p. 24).

In 1986, when Lake Michigan was above $582.00 \mathrm{ft}$, water-level data at surface-water sites S-7, S-23, D-36S, D-54S, and E-16S indicate that the drainage divide in the west branch of the Grand Calumet River was absent. During 1986, Lake Michigan was draining to the Illinois River Basin through the Indiana Harbor Canal and to the west branch of the Grand Calumet River.

In addition to long-term lake-level fluctuations, seiches (temporary buildups of lake water near the shore because of local atmospheric pressure and wind) can cause short-term fluctuations of more than $3 \mathrm{ft}$ within a few hours. Hourly Lake Michigan levels from the NOAA gage at Calumet Harbor, Ill., for July 20, 1987, indicate a 2.23-ft rise in lake level in 3 hours; an even larger fluctuation is noted for February 7 and 8, 1987, when Lake Michigan rose $3.77 \mathrm{ft}$ in 13 hours (Jeff Oyler, National Oceanic and Atmospheric Administration, written commun., 1992).

Although long-term water-level changes in Lake Michigan immediately affect levels in the Indiana Harbor Canal and parts of the Grand Calumet River, seiche (short-term) fluctuations are not fully transported upstream. Short-term seiche fluctuations are damped out by surfacewater/ground-water interaction. Although smaller in amplitude, seich-induced fluctuations in water level were reported 7 river miles upstream from Lake Michigan at site C-16S, on the east branch of the Grand Calumet River (Fenelon and Watson, 1993, p. 24).

\section{Ground-Water/Surface-Water Interaction}

The ground-water and surface-water systems are hydraulically connected. The moderate waterlevel fluctuation of surface-water bodies not affected by Lake Michigan further indicates the connection with the ground water. In a groundwater model simulation, Fenelon and Watson (1993, p. 37) achieved a reasonable flow balance with a 1 -ft-thick riverbed having a vertical hydraulic conductivity of $1 \mathrm{ft} / \mathrm{d}$. Water levels in 
wells near the Indiana Harbor Canal respond virtually immediately to changes in surface-water level. Analysis of water-level data from the datacollection network indicates that the water tablenormally slopes toward streams, ditches, sewers, the Indiana Harbor Canal, and Lake Michigan. In the vicinity of ground-water/surface-water transects, the water table near the river is nearly flat in the summer but increases in slope during the winter. The steepest slope noted in water-table mapping was less than $20.0 \mathrm{ft} / \mathrm{mi}$.

Data collected hourly at transects A-11S5-10-20; C-5-10-15-16S; D-25-30-35-36S; D-54S-55-60-65; and E-10-15-16S indicated that evapotranspiration was significant at densely vegetated sites (Fenelon and Watson, 1993, p. 29). Further, evapotranspiration and lack of precipitation seem to have induced local reversals in the slope of the water table at two transect sites. Ground-water troughs as much as $1 \mathrm{ft}$ below the level of nearby surface water were inferred from summer 1986 data. These troughs formed adjacent to the Grand Calumet River (C-16S) near wells $\mathrm{C}-5, \mathrm{C}-10$, and $\mathrm{C}-15$, and adjacent to the Indiana Harbor Canal (D-45S)near wells D-55, D-60 and D-65. Fenelon and Watson (1993, p. 29) report that the low point of these troughs can move as much as $500 \mathrm{ft}$ inland from the river. Examination of the transect data collected since Lake Michigan returned to near-normal levels indicate that troughs in the water table may no longer be present at these two sites.

\section{Changes Induced by Dewatering}

Ground-water levels in large parts of the study area are lowered by sewers, ditches, pumping, and remedial-action dewatering. Ground-water flow into leaky sewer lines can lower ground-water levels in isolated spots or in widespread areas. Two areas where the ground-water altitude is maintained below an altitude of $580 \mathrm{ft}$ are noted in figures 8 through 13. The first area is near well E-1, south of Wolf Lake, near the Indiana-Illinois State line in Hammond (fig. 2). The second area is near well D-50, north of the west branch of the Grand Calumet River and west of the Indiana Harbor Canal in East Chicago. Another area dewatered by leaky sewers is near well D-45, east of the Indiana Harbor Canal in East Chicago, where the ground-water surface is lowered to an altitude of 580 to $582 \mathrm{ft}$ above sea level. One model of the ground-water-flow system suggests the natural flow-system water levels were 5 to $10 \mathrm{ft}$ higher than today (Watson and others, 1989, p. 37). Although other areas may be dewatered by leaky sewers, the effect is not detectable in data from the water-level network.

In areas where land-surface elevations are less than $10 \mathrm{ft}$ above the surface of Lake Michigan, sewer lines may have been constructed below the ground-water surface. For these sewers to drain, lift stations must raise their contents. Dewatering occurs when ground-water infiltrates the sewer lines and is pumped to sewage-treatment facilities. During the period of maximum levels of Lake Michigan, ground-water levels near well D-45 were slightly lower than during periods of normal lake level. Sewers are the most likely cause for this minor lowering of ground-water levels in 1986 and 1987. Water-levels in well D-45 indicate that leaky-sewer dewatering was more effective during periods of high ground-water levels.

Ditches are another method used to drain large areas and former wetlands in the study area. Many roads, railroads, airports, and light industrial areas in the study area are drained by ditches. Because sand is at the surface in most of the area, precipitation infiltrates quickly, and ditching is used mainly to lower ground-water levels. In the western half of the area and north of the Grand Calumet River, ditches drain the west end of the Gary airport; railroad grades; and numerous interstate, Federal, State, and local highways and roads. In addition, the Indiana Harbor Canal functions as a ditch when the level of Lake Michigan is normal. Hydraulic gradients in ditched areas are approximately $2 \mathrm{ft} / \mathrm{mi}$, whereas gradients approach $8 \mathrm{ft} / \mathrm{mi}$ in similar but unditched areas.

Most construction and earth-moving operations in the area require dewatering. Well B-1 was installed near an operating sand borrow pit. Initial water-level data indicated that flow was from the Grand Calumet River toward well B-1. 
In April 1988, the dewatering system was not operating; ground-water levels had rebounded nearly $4 \mathrm{ft}$, and flow at well B-1 was toward the Grand Calumet River. By July 1988, however, ground-water levels at B-1 were again lower than the river, indicating that dewatering had resumed. Water levels near well B-1 rose slowly from July 1988 through September 1990, finally returning to normal in 1991. From 1991 through September 1992, ground-water-flow directions were again normal, indicating that the sand-mining operation was finished.

Dewatering for sewer construction in February 1986 is recorded in the data from well C-20. The sewer construction apparently was completed by late March because water levels appear to have recovered by April 1986.

Another use of dewatering in the study area is to restrict the movement of contaminants across property boundaries and to recover soluble and insoluble contaminants from the aquifer. Dewatering wells can be arranged to create ground-water-flow barriers, preventing contaminants from moving away from the source. Dewatering also can be used to create a depression in the ground-water surface, under the source of contamination. Floating contaminants then can be recovered from the depression. Large areas in Whiting are dewatered for collection of hydrocarbons from beneath a major refinery (Gregory D. Skannal, American Oil Company, oral commun., 1992).

\section{Water-Table Configuration}

During August 1985-September 1992, monthly precipitation in the study area ranged from $0.07 \mathrm{in}$. (February 1987) to $9.45 \mathrm{in.}$ (August 1990), as recorded at Hobart, Ind. (National Oceanic and Atmospheric Administration, 1987, p. 3; National Oceanic and Atmospheric Administration, 1990, p. 3); the level of Lake Michigan ranged from $577.00 \mathrm{ft}$ (1800 hours, November 29, 1989) to $584.21 \mathrm{ft}$ above sea level (1700 hours, August 26, 1986) at Calumet Harbor, Ill. (Jeff Oyler, National Oceanic and Atmospheric Administration, written commun., 1992). Yet, maps of the water table (figs. 8 through 13) show that water-level changes were minor and that the configuration of the water table remained nearly stable throughout the study period.

The combined effects of sewers, ditches, the Indiana Harbor Canal, and dewatering systems have stabilized water-table fluctuations in several areas. The water-table altitude was nearly constant east and west of the Indiana Harbor Canal in Gary, East Chicago, and Hammond, Ind. Another area where the water table was stable was north and east of Lake George in Whiting and Hammond.

Comparison of water-table maps from various dates (figs. 8 to 13), shows that most of the changes were south of the Grand Calumet River. Of particular interest in the area north of the Grand Calumet River is the relation of ground-water levels to the stage of Lake Michigan, the position of the 585-ft contour line from Gary Harbor to the Indiana Harbor Canal, and the areas where groundwater levels are below the 582.5 -ft contour line in Hammond, Whiting, and East Chicago. Of particular interest in the area south of the Grand Calumet River is the area where water levels exceed an elevation of $595 \mathrm{ft}$ above sea level, including the presence or absence of water levels at elevations greater than $600 \mathrm{ft}$.

The 585-ft contour line west of the Indiana Harbor and the 585-ft contour line in the peninsular lake-fill area east of the Indiana Harbor (figs. 8, 9, 10,12 and 13) are based on water-level data from sources other than the USGS well network (Richard A. Harris, American Oil Company, written commun., 1992; Tom Barnett, Inland Steel Company, written commun., 1993). A water level at an elevation greater than $585 \mathrm{ft}$ is indicated at USGS well C-2 in figure 11.

Figure 8 shows the water table for May 1986 when Lake Michigan was at a record high level. The lake level extends west to within $0.8 \mathrm{mi}$ of the Indiana-Illinois State line through the west limb (Lake George arm) of the Indiana Harbor Canal. Ground-water and surface-water levels also were high during May 1986. A small depression due to pumping is indicated at well HWT14-5, about $3 \mathrm{mi}$ west of Gary Harbor. (This depression in the water table also is present in figs. 9, 12, and 13). 


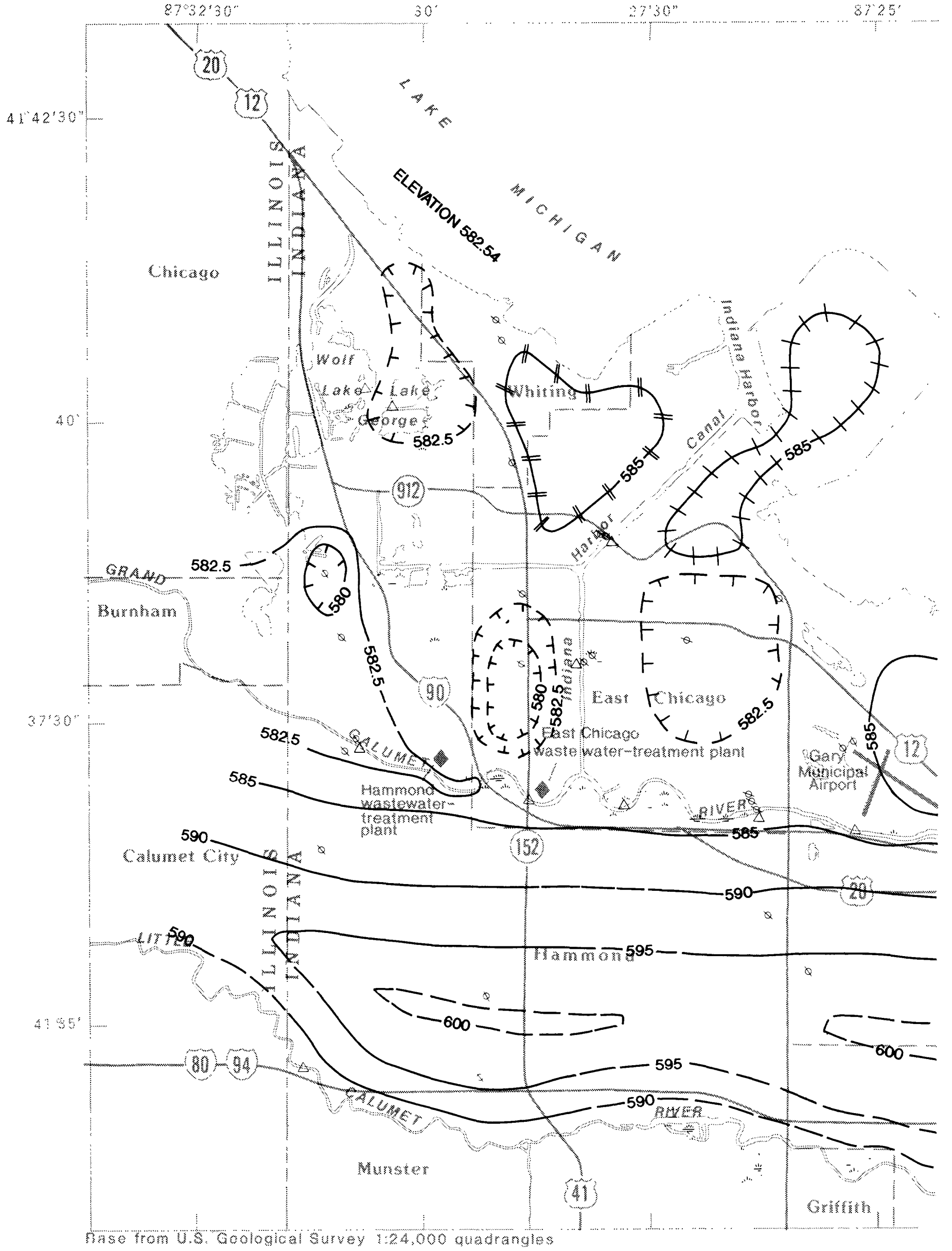

Figure 8. Water table in the Calumet aquifer, May 9-16, 1986. (Level of Lake Michigan during the preceding 5 months was below average.) 


\section{EXPLANATION}
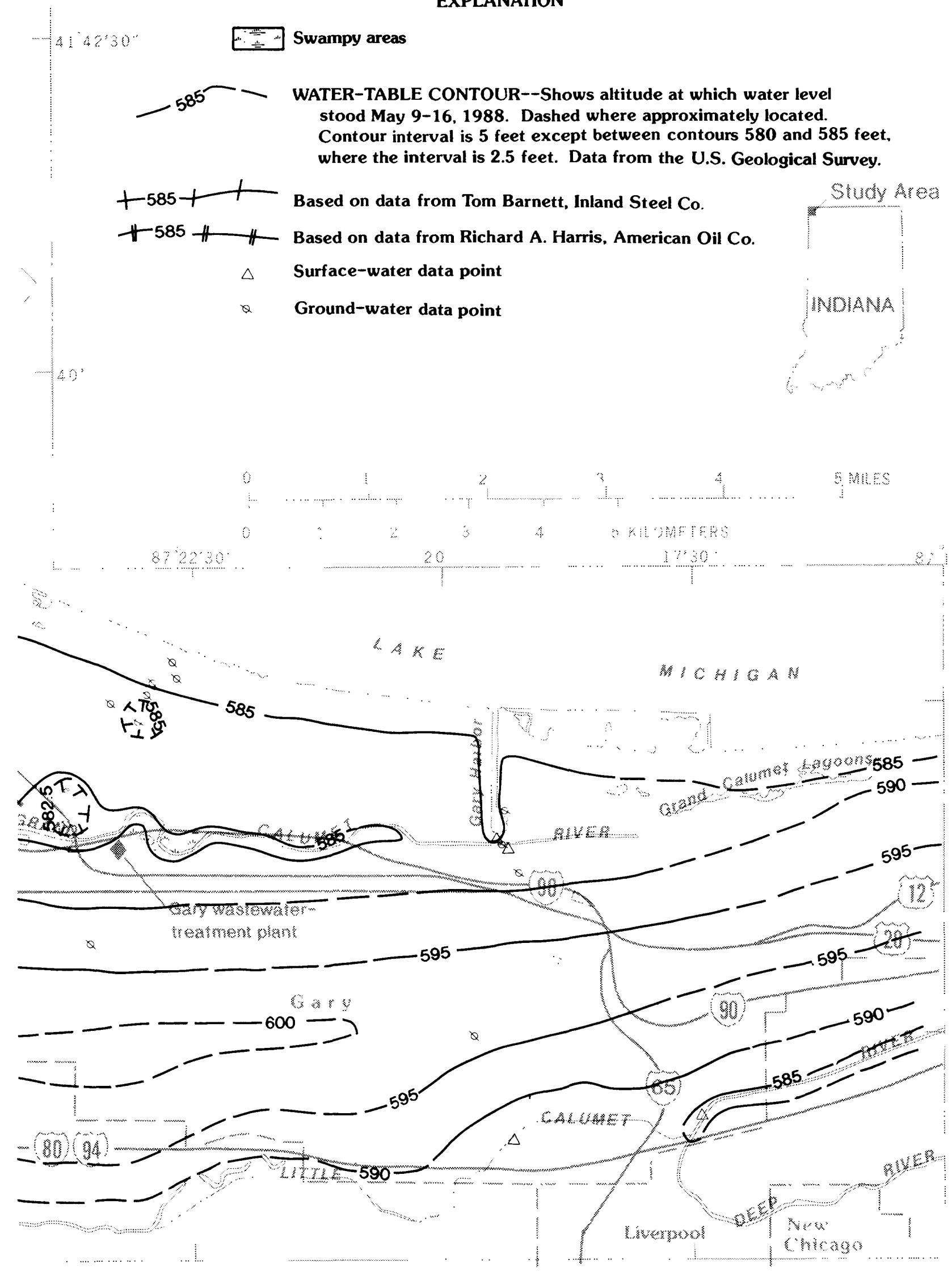

is at record high, and ground-water levels are above average. Precipitation 


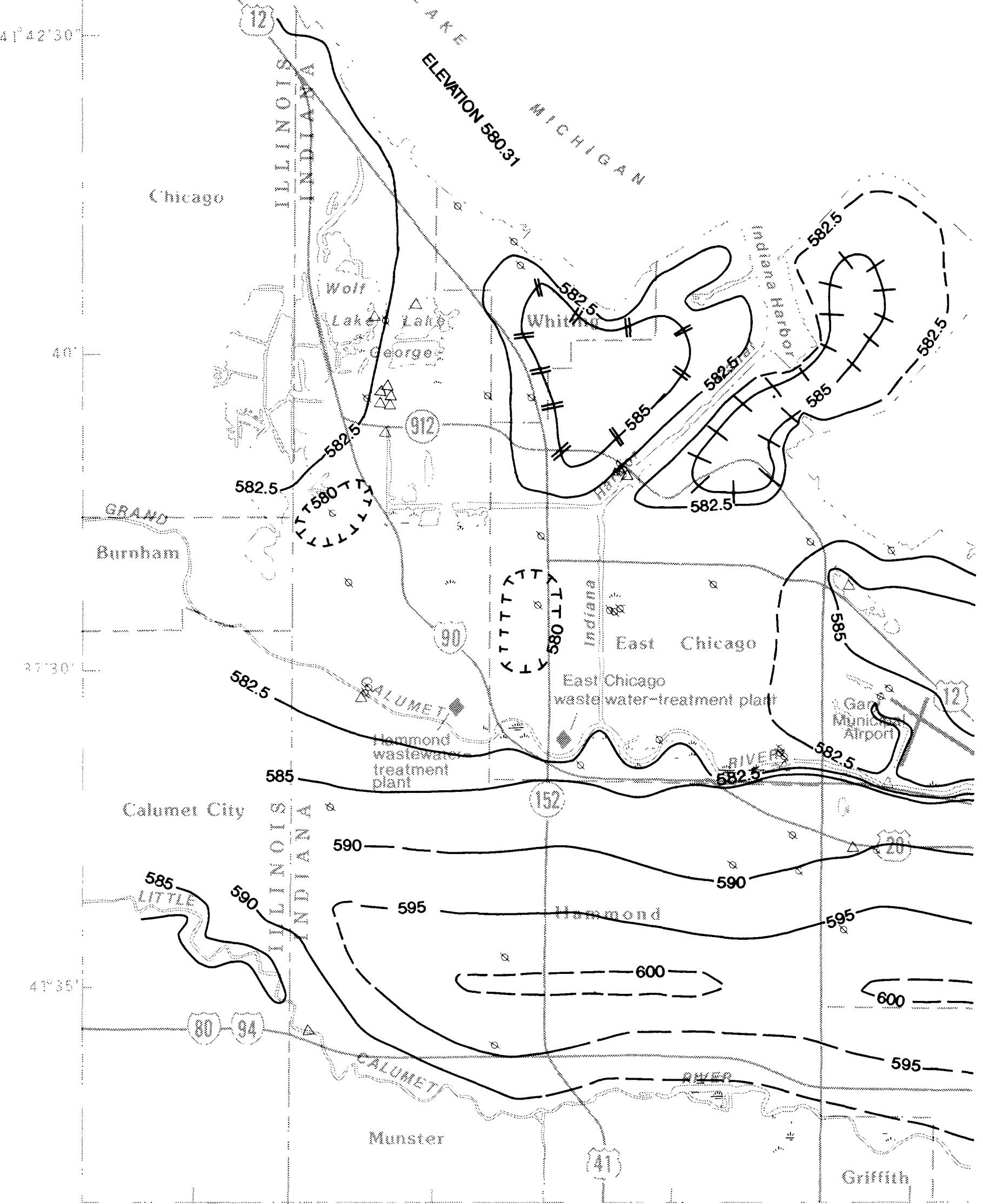

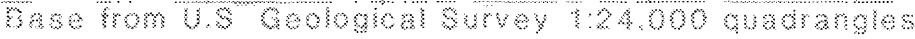

Figure 9. Water table in the Calumet aquifer, July 5-7,1988. (Level of Lake Michigan during peak of 1988 drought. Precipitation was below normal by approximately 7 inches 


\section{EXPLANATION}

$212430^{\circ} \quad$ Swampy areas

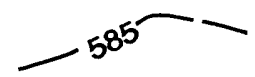

WATER-TABLE CONTOUR--Shows altitude at which water level

stood May 9-16, 1988. Dashed where approximately located.

Contour interval is 5 feet except between contours 580 and 585 feet,

where the interval is $\mathbf{2 . 5}$ feet. Data from the U.S. Geological Survey.

$+585+1$ Based on data from Tom Barnett, Inland Steel Co.

廿585 \#_ Based on data from Richard A. Harris, American Oil Co.

Surface-water data point

Ground-water data point

Sury Area

(1)

NDIANA

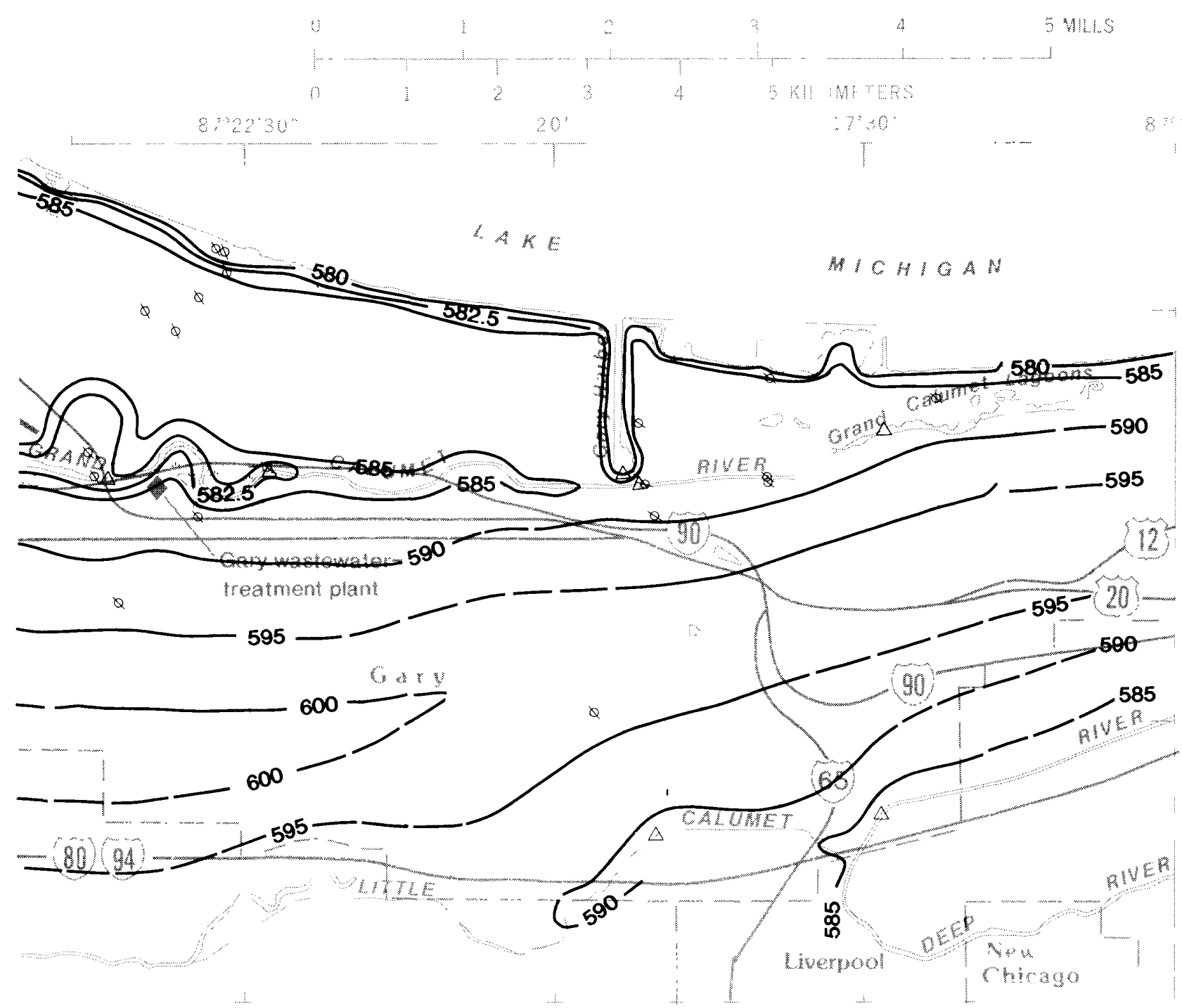

of Lake Michigan was below normal, lowest in the data set, and ground-water January and February was above average.) 


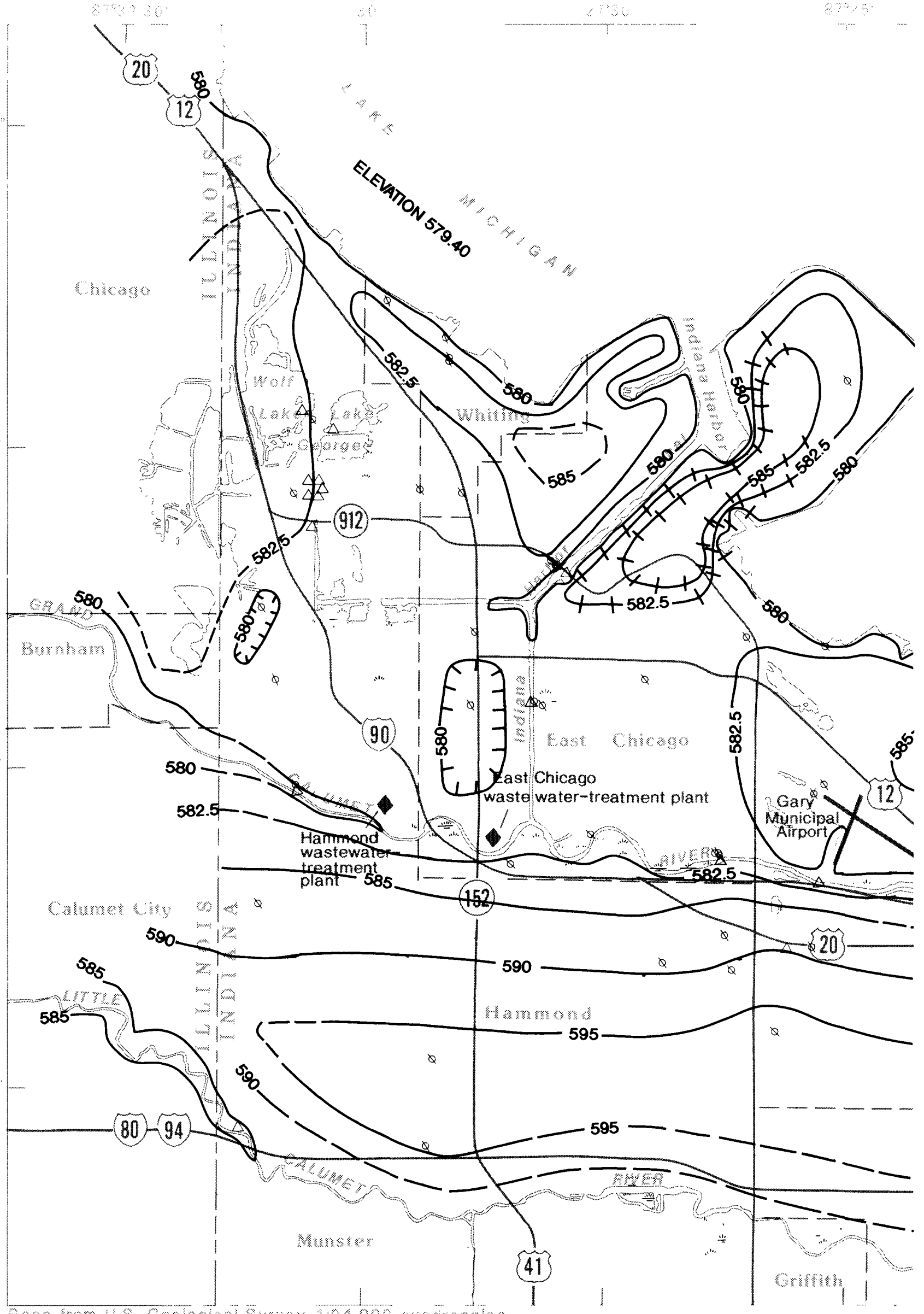

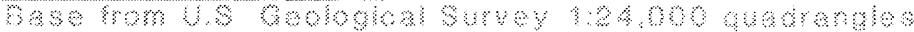

Figure 10. Water table in the Calumet aquifer, October 11-13, 1988. (Level of Lake the preceding 3 months was near average.) 


\section{EXPLANATION}

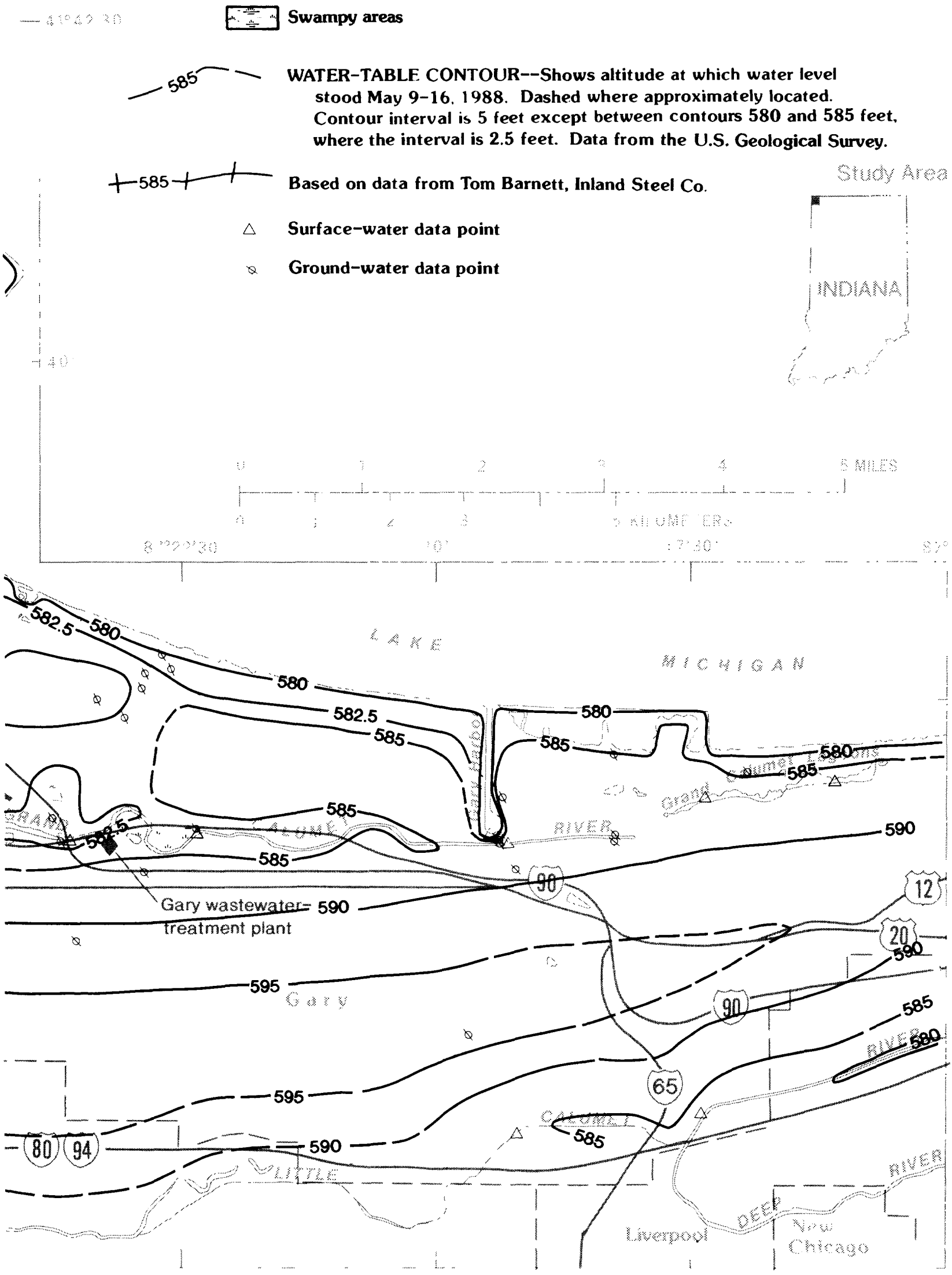

Michigan was normal, and ground-water levels were low. Precipitation during 


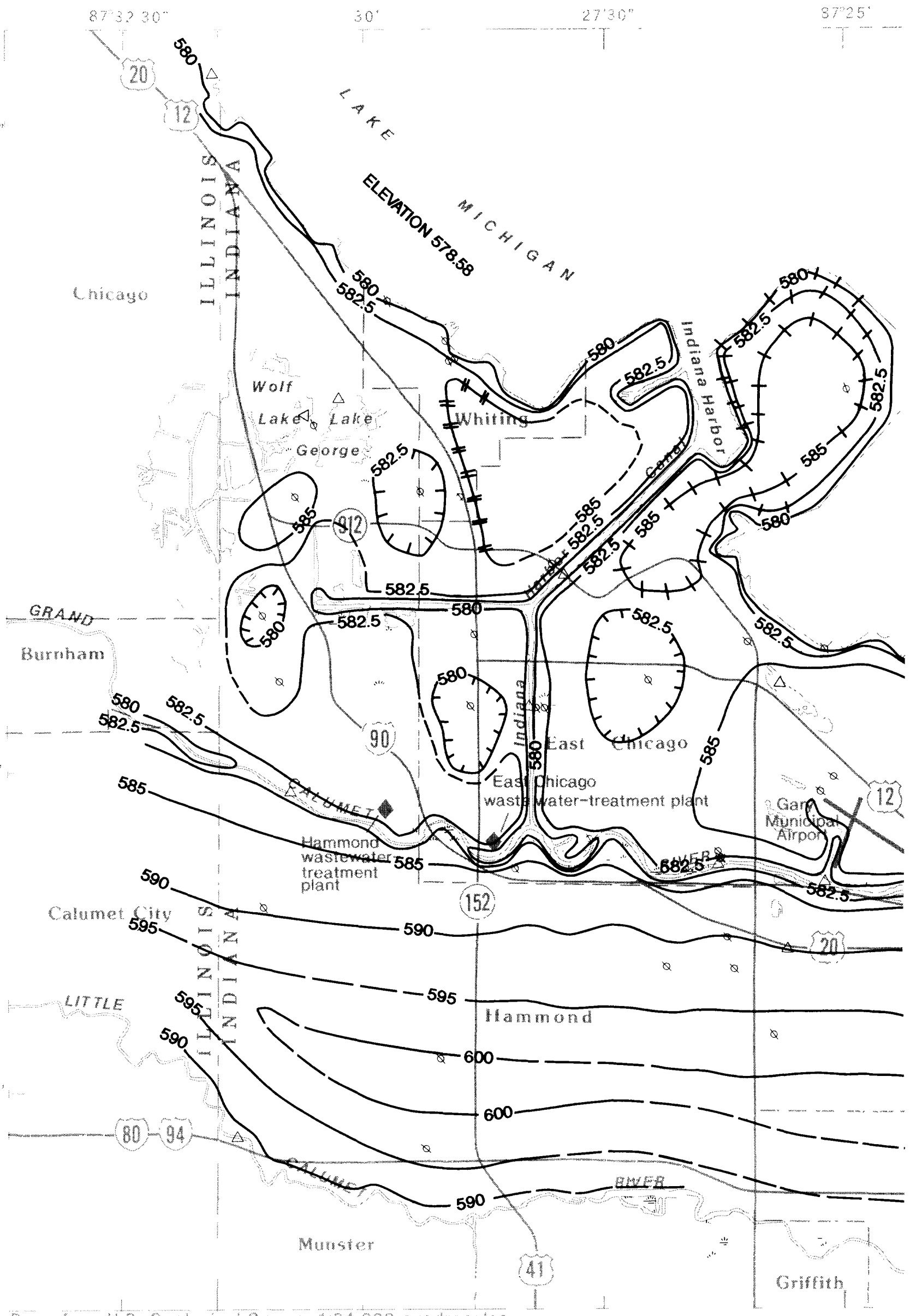

Base mom Us coologran Surva 124000 quadrangles

Figure 11. Water table in the Calumet aquifer, February 26-March 1, 1990. (Level levels were average. Surface-water levels were above average. Precipitation during 


\section{EXPLANATION}
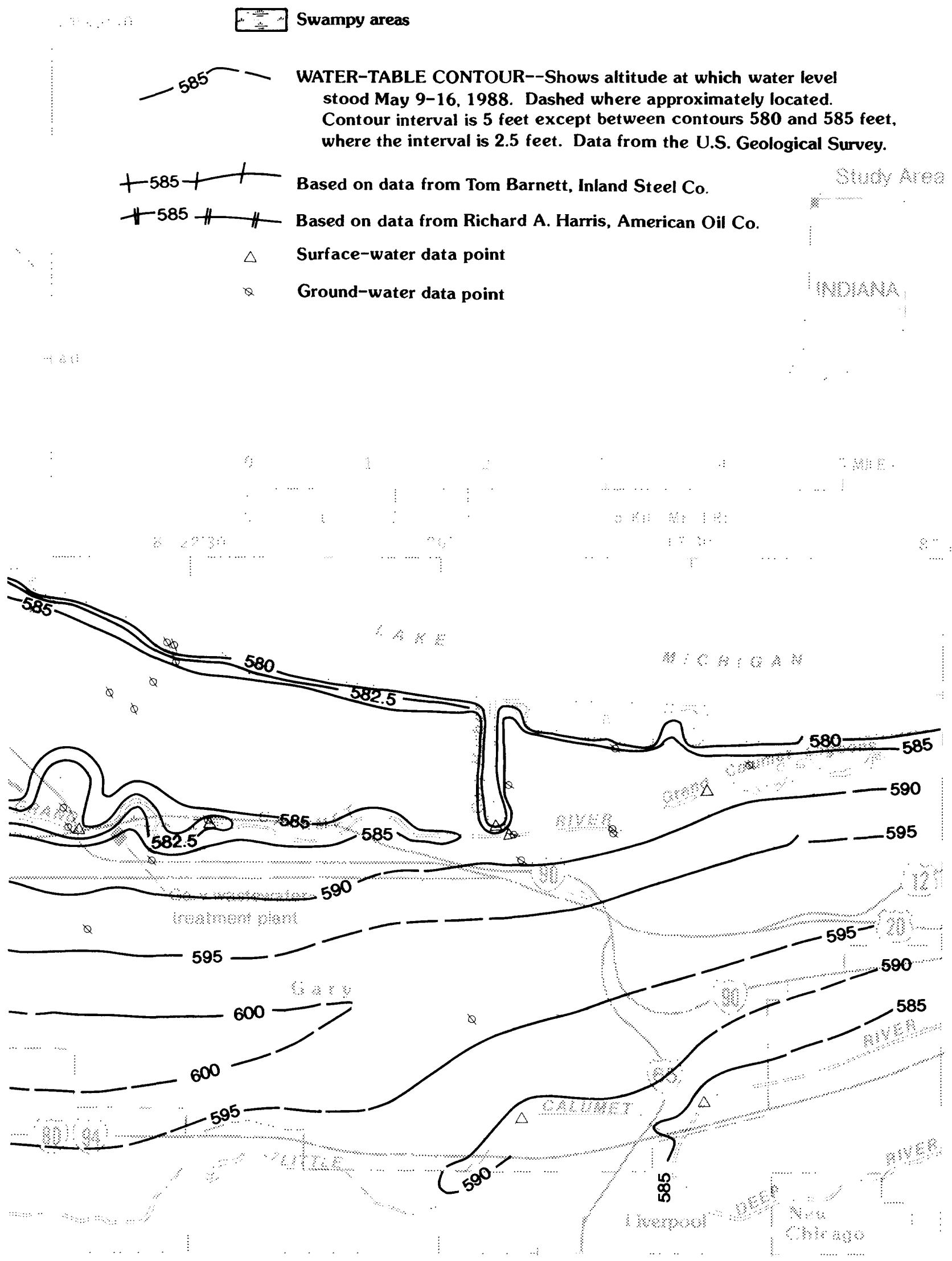

of Lake Michigan was below normal, lowest in the data set, and ground-water January and February was above average.) 


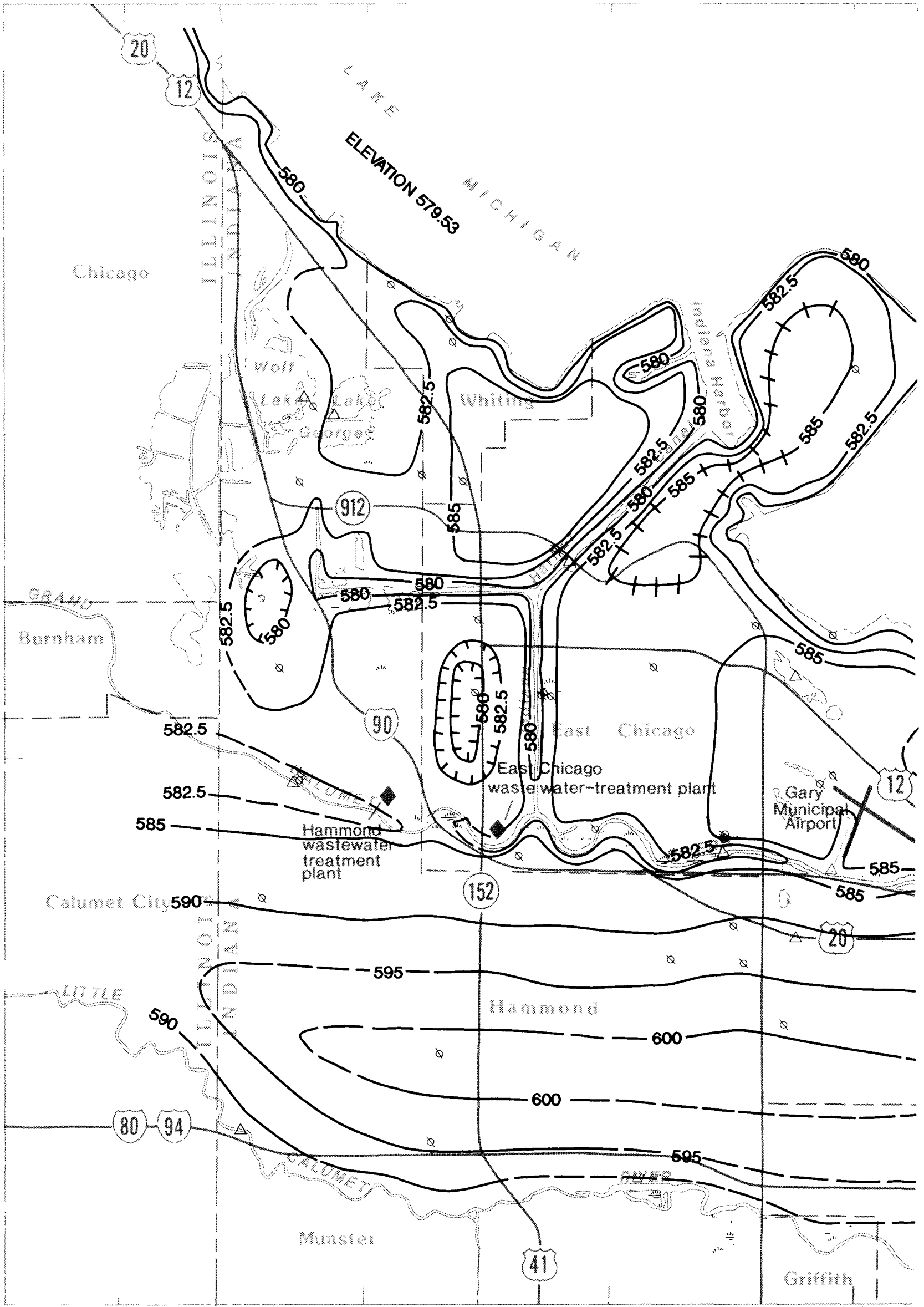

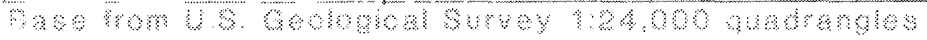

Figure 12. Water table in the Calumet aquifer, November 26-29, 1990. (Level of levels were high. Precipitation was above average, with an excess of more than 


\section{EXPLANATION}
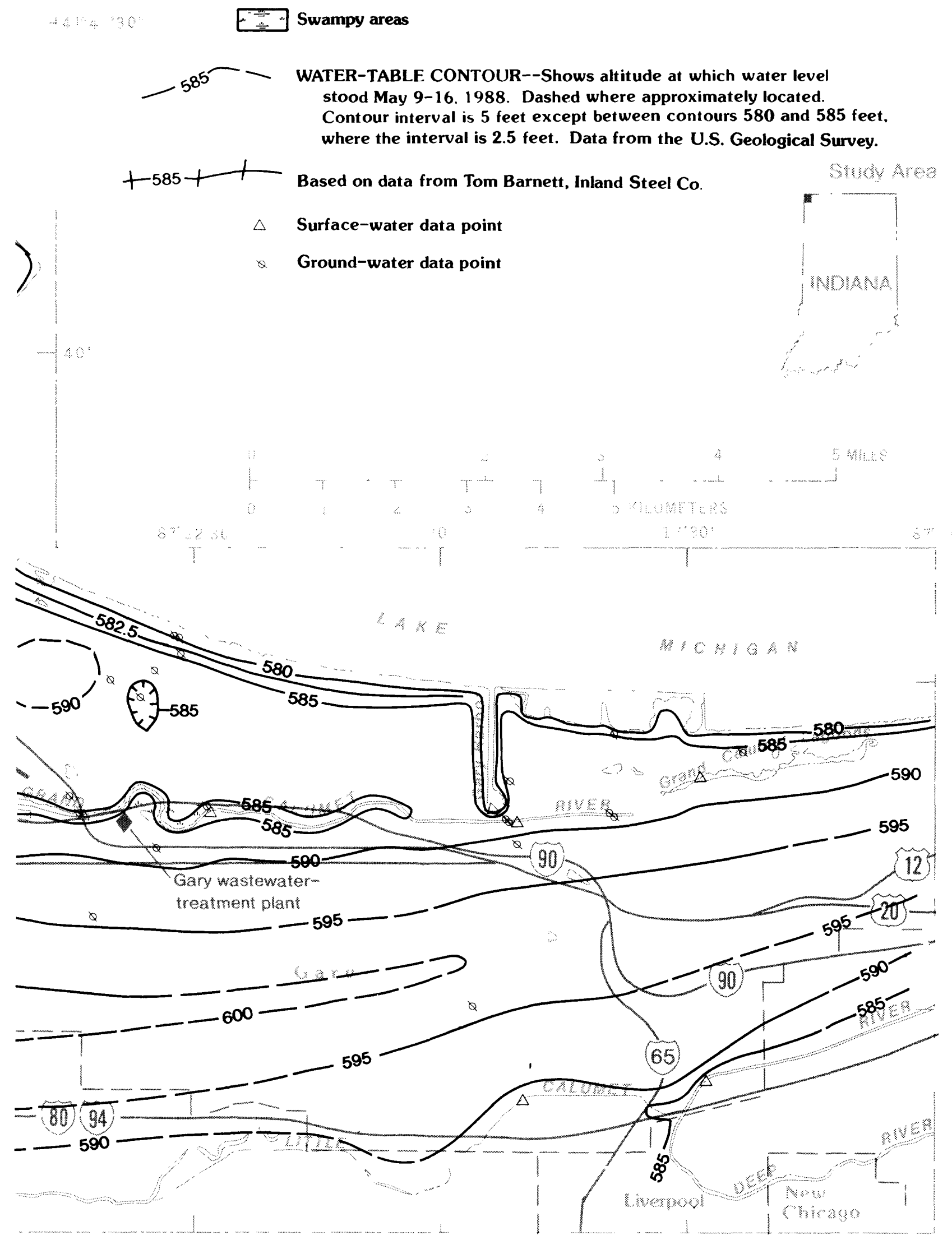

Lake Michigan is near normal, and both ground-water and surface-water

12 inches measured during preceding 4 months.) 


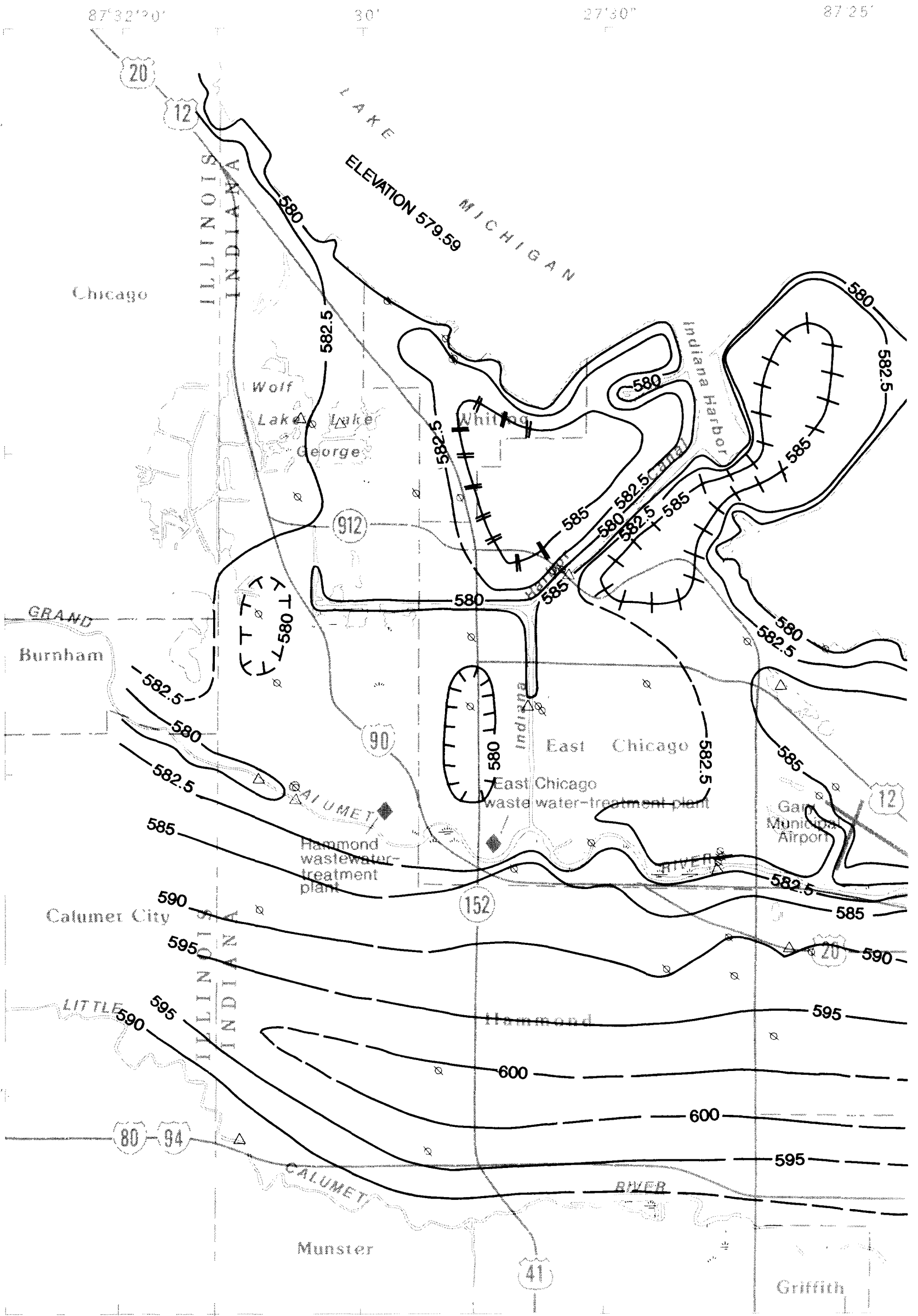

Base Fiom US Cuological Survey 124.000 quadrangles

Figure 13. Water table in the Calumet aquifer, September 8-11, 1992. (Level of Lake Precipitation was heavy during the period of data collection). 


\section{EXPLANATION}

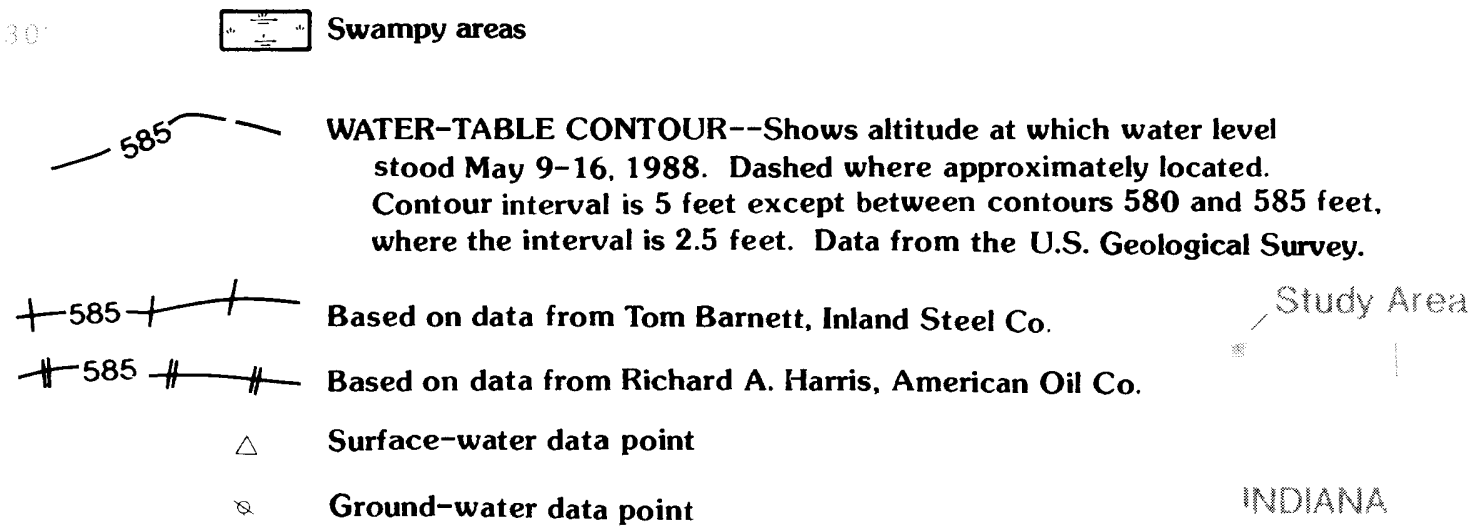

MDINA

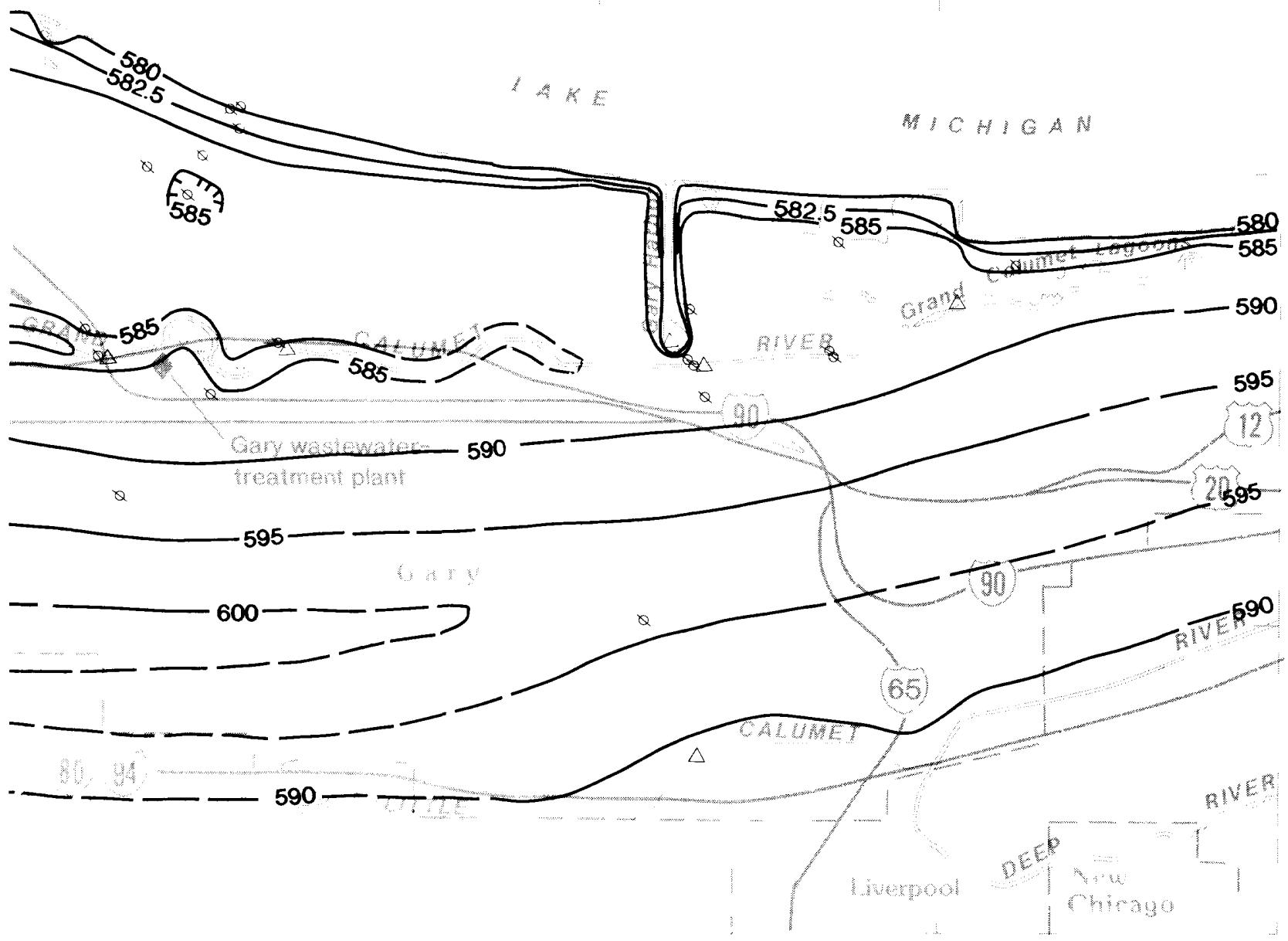

Michigan is near normal, and ground-water levels were average. 
South of the Grand Calumet River, water levels greater than $600 \mathrm{ft}$ are mapped in two areas on the basis of local hydraulic gradients and landsurface configuration; however, the contour lines are dashed because ground-water-level data are unavailable to confirm this interpretation.

Figure 9 shows the water table in July 1988 when Lake Michigan was at normal level and ground-water levels were low. As in figure 8, water levels greater than $600 \mathrm{ft}$ are mapped in two areas south of the Grand Calumet River on the basis of local hydraulic gradients. The $600-\mathrm{ft}$ contour lines are dashed because ground-waterlevel data are unavailable to document this interpretation.

Figure 10 shows the water-table surface in October 1988 when Lake Michigan was again at normal level and the ground-water levels were again low. No 600-ft contour is indicated on this figure because of the decrease in the width of the ground-water divide above the 595-ft contour south of the Grand Calumet River.

Figure 11 shows the water table in March 1990 when Lake Michigan was at a low level and ground-water levels were about average. The 600-ft contour line is shown south of the Grand Calumet River in the map for March 1990 on the basis of water-level data for well D-70 (the $600-\mathrm{ft}$ contour in figs. 12 and 13 also is based on data for well D-70).

Figure 12 shows the water levels in November 1990 after a period of heavy precipitation.

Although Lake Michigan was at normal level, water levels at Wolf Lake and Lake George are high. This is the only water-table map in which the 585-ft contour level is exceeded west of the Indiana Harbor Canal in Whiting, Ind. Groundwater levels are below an altitude of $582.5 \mathrm{ft}$ above sea level only in sewered areas.

Figure 13 shows the water table in September 1992 when Lake Michigan was at normal level, and the ground-water levels also were about average. Heavy rains fell midway through the September 1992 measurement, and some of the mapped water levels may indicate this precipitation.

\section{SUMMARY AND CONCLUSIONS}

This report lists and summarizes 2,328 measurements of ground-water and surface-water levels from a network of 96 sites in northern Lake County, Ind., made from August 1985 through September 1992. The study of the ground-water and surface-water flow in the vicinity of the Grand Calumet River and the Indiana Harbor Canal was done to provide information needed to determine the potential for ground-water contaminants to enter Lake Michigan. Data are reported in tables and in six water-table maps. Each of the six maps represents a particular time period and particular set of hydrologic conditions. Data presented in this report are stored in the USGS National Water Information System (NWIS) data base.

Ground-water levels in the study area commonly reached an annual maximum in June or July. A smaller peak in ground-water levels occurred during February and March of most years. Minimum ground-water levels occurred in September or October in most years. The regional ground-water flow in the Calumet aquifer is generally toward the major streams, the Indiana Harbor Canal, and Lake Michigan. Local groundwater flow is toward ditches, leaky sewers, and dewatering systems.

The greatest surface-water-level fluctuations are at sites hydraulically connected to Lake Michigan. Within the data, a maximum surfacewater fluctuation of $4.14 \mathrm{ft}$ was measured in the Indiana Harbor Canal $1.6 \mathrm{mi}$ inland from the lake. The measured fluctuation of Lake Michigan at the USGS network site was $3.80 \mathrm{ft}$. Water-level fluctuations on the east branch of the Grand Calumet River ranged from $1.06 \mathrm{ft}$ (upstream) to $2.45 \mathrm{ft}$ (downstream) during the 7 years of data collection. The low magnitude of these fluctuations is the result of (1) the high proportion of effluent in the river and the fairly constant rate of effluent discharge; (2) the low relief of the basin; (3) infiltration of precipitation directly into the Calumet aquifer; (4) the high hydraulic conductivity of the aquifer, which stabilizes the rate of discharge; and (5) the hydraulic connection between the Grand Calumet River and the Calumet aquifer. Similarly, ground-water fluctuations in the Calumet aquifer have ranged from a minimum of $0.40 \mathrm{ft}$ (near the 
Grand Calumet River at east end) to a maximum of $5.01 \mathrm{ft}(0.80 \mathrm{mi}$ south of the Grand Calumet River, east of the canal). The mean ground-water fluctuation was about $2.3 \mathrm{ft}$.

Below-average precipitation was reported throughout Indiana from October 1987 through September 1988. Although most of northwestem Indiana was affected, the 1988 drought did not severely affect water levels in the Calumet aquifer. The drought of 1988 , however, did reverse vertical flow gradients in several areas of the Calumet aquifer.

Lake Michigan was at record high levels from fall 1985 through summer 1986 . Since 1986, the level of Lake Michigan has dropped to slightly below the normal pool level of $580 \mathrm{ft}$. High lake levels created backwater effects about $11.0 \mathrm{mi}$ upstream from Lake Michigan on the east branch of the Grand Calumet River. Similar backwater effects on the west branch of the Grand Calumet River were observed as far west as the East-West Toll Road (Interstate 90) bridge (1.2 mi west of the Indiana Harbor Canal). When the level of Lake Michigan is below approximately $582.00 \mathrm{ft}$, a surface-water divide develops in the west branch of the Grand Calumet River near the East-West Toll Road bridge. In early 1986, Lake Michigan stage exceeded $582.00 \mathrm{ft}$ above sea level, and water-level data indicate that the lake was draining into the Illinois River drainage basin through the Indiana Harbor Canal and the west branch of the Grand Calumet River. Water levels in the Indiana Harbor Canal and parts of the Grand Calumet River reflect water-level changes in Lake Michigan. Previous authors have reported that these changes are virtually immediate.
The stability of water levels in the Calumet aquifer is such that, unless a major recharge event occurs or Lake Michigan's level changes significantly during data collection, water levels should vary less than $0.2 \mathrm{ft}$ in a 4-day data-collection period. Thus, the data within most sets can be treated as if collected simultaneously.

In the vicinity of ground-water/surface-water transects, the water table near the river is nearly flat in the summer but increases in slope during the winter. The steepest slope noted in water-table mapping was less than $20.0 \mathrm{ft} / \mathrm{mi}$. Much of the study area has ground-water flow gradients of less than $2 \mathrm{ft} / \mathrm{mi}$.

Ground-water levels in large parts of the study area are lowered by sewers, ditches, pumping, and remedial-action dewatering. In sewered areas, leaky sewer lines can lower ground-water levels in isolated spots or widespread areas. Sewers also allow dewatering below the level of Lake Michigan. Ditches also have been effective in dewatering large areas. The Indiana Harbor Canal, which functions as a ditch when the level of Lake Michigan is normal, extends the lake level over 3.75 miles inland from the shore. Ground-water gradients in ditched areas are lower than in naturally drained areas. Shallow ground water throughout the area necessitates dewatering for construction and earth-moving operations. Large areas in Whiting, Ind., are dewatered to collect floating contaminants and to prevent soluble contaminants from escaping property boundaries. 


\section{REFERENCES CITED}

Crawford, C.G., and Wangsness, D.J., 1987, Streamflow and water quality of the Grand Calumet River, Lake County, Indiana, and Cook County, Illinois, October 1984: U.S. Geological Survey Water-Resources Investigations Report 86-4208, 137 p.

Fenelon, J.M., and Watson, L.R., 1993, Geohydrology and water quality of the Calumet aquifer, in the vicinity of the Grand Calumet River/Indiana Harbor Canal, northwestern Indiana: U.S. Geological Survey Water-Resources Investigations Report 92-4115, $151 \mathrm{p}$.

Fowler, K.K., 1992, Description and effects of 1988 drought on ground-water levels, streamflow, and reservoir levels in Indiana: U.S. Geological Survey Water-Resources Investigations Report 91-4100, $91 \mathrm{p}$.

Hartke, E.J.; Hill, J.R.; and Reshkin, Mark, 1975, Environmental geology of Lake and Porter Counties, Indiana-an aid to planning: Indiana Department of Natural Resources, Geological Survey Special Report 11, 57 p.

Malott, C.A., 1922, The physiography of Indiana, in Logan, W.N., and others, Handbook of Indiana geology: Indiana Department of Conservation, Division of Geology Publication 21, part II, p. 59-256.

National Oceanic and Atmospheric Administration, 1982, Monthly normals of temperature and precipitation, and heating and cooling degree days, 1951-80--Indiana: National Oceanic and Atmospheric Administration, Climatography of the United States No. 81, p. 13.
National Oceanic and Atmospheric Administration, 1987, Climatological data-annual summary, Indiana, 1987: [National Oceanic and Atmospheric Administration, Climatological annual summary] v.92, no 13, p. 7 .

National Oceanic and Atmospheric Administration, 1990, Climatological data-annual summary, Indiana, 1990: [National Oceanic and Atmospheric Administration, Climatological annual summary] v. 95 no. 13 , p. 7 .

Rosenshein, J.S., and Hunn, J.D., 1968, Geohydrology and ground-water potential of Lake County, Indiana: Indiana Department of Natural Resources, Division of Water Resources Bulletin 32, 22 p.

Schneider, A.F., and Keller, S.J., 1970, Geologic map of the $1^{\circ} \times 2^{\circ}$ Chicago Quadrangle, Indiana, Illinois, and Michigan, showing bedrock and unconsolidated deposits: Indiana Geological Survey Regional Geologic Map 4, Chicago Sheet, Part B, scale 1:250,000.

U.S. Geological Survey, 1986-92, Water resources data for Indiana, water years 1986-92: U.S. Geological Survey Water Data Reports IN-86-1 to IN-92-1 (published annually).

Watson, L.R.; Shedlock, R.J.; Banaszak, K.J.; Arihood, L.D.; and Doss, P.K., 1989, Preliminary analysis of the shallow ground-water system in the vicinity of the Grand Calumet River/Indiana Harbor Canal, northwestern Indiana: U.S. Geological Survey Open-File Report 88-492, 45 p. 
SUPPLEMENTAL DATA 


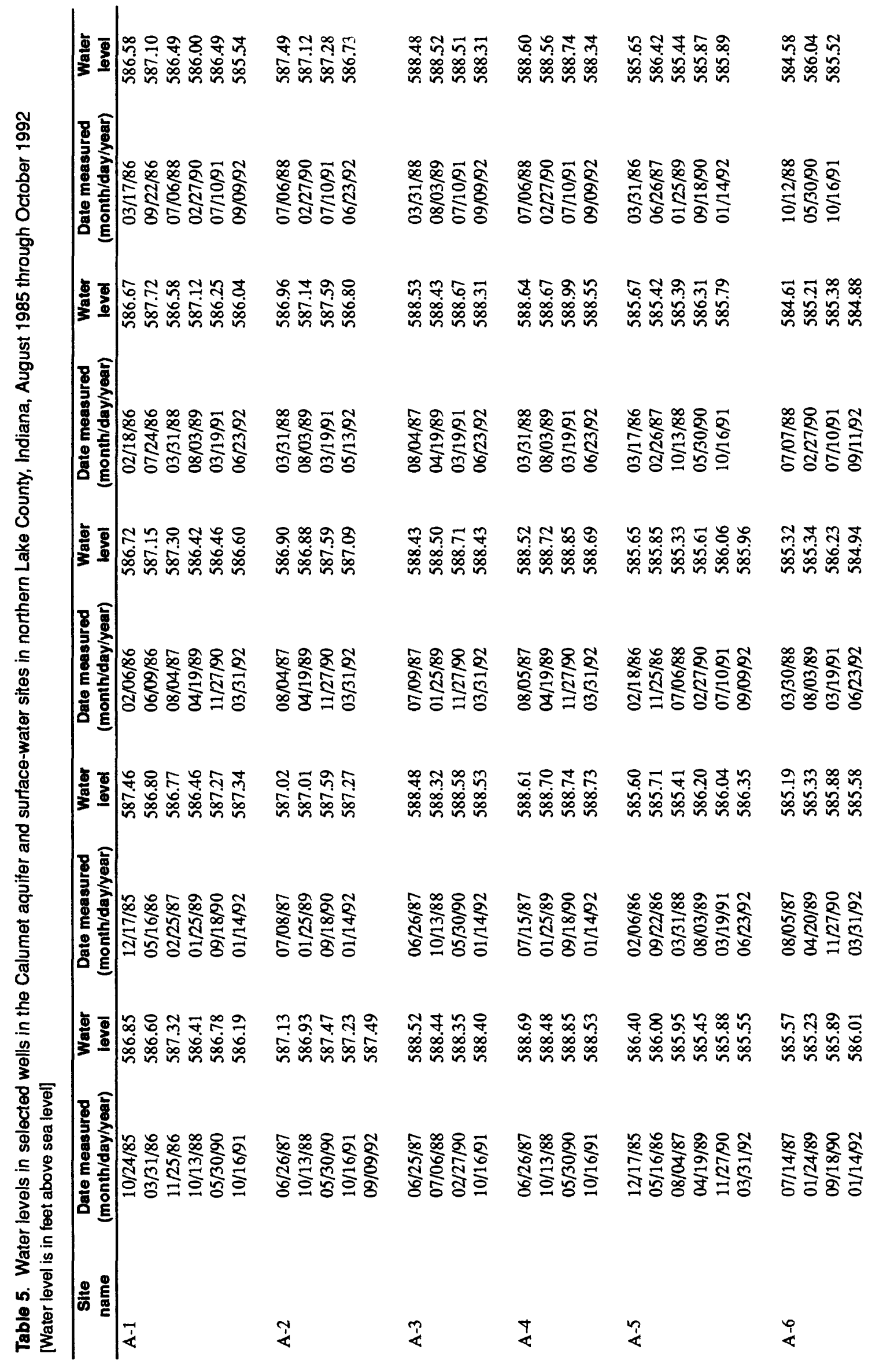




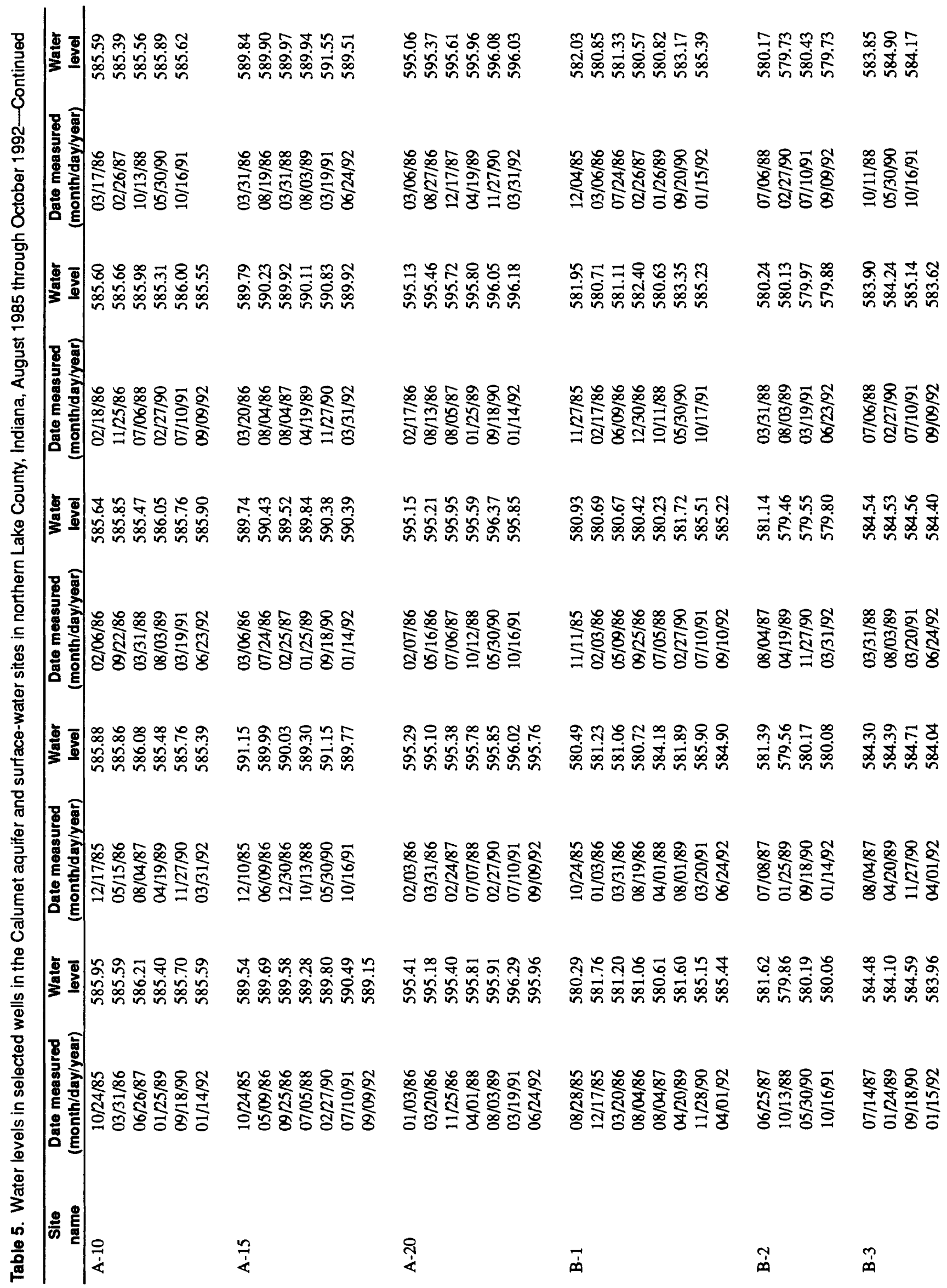




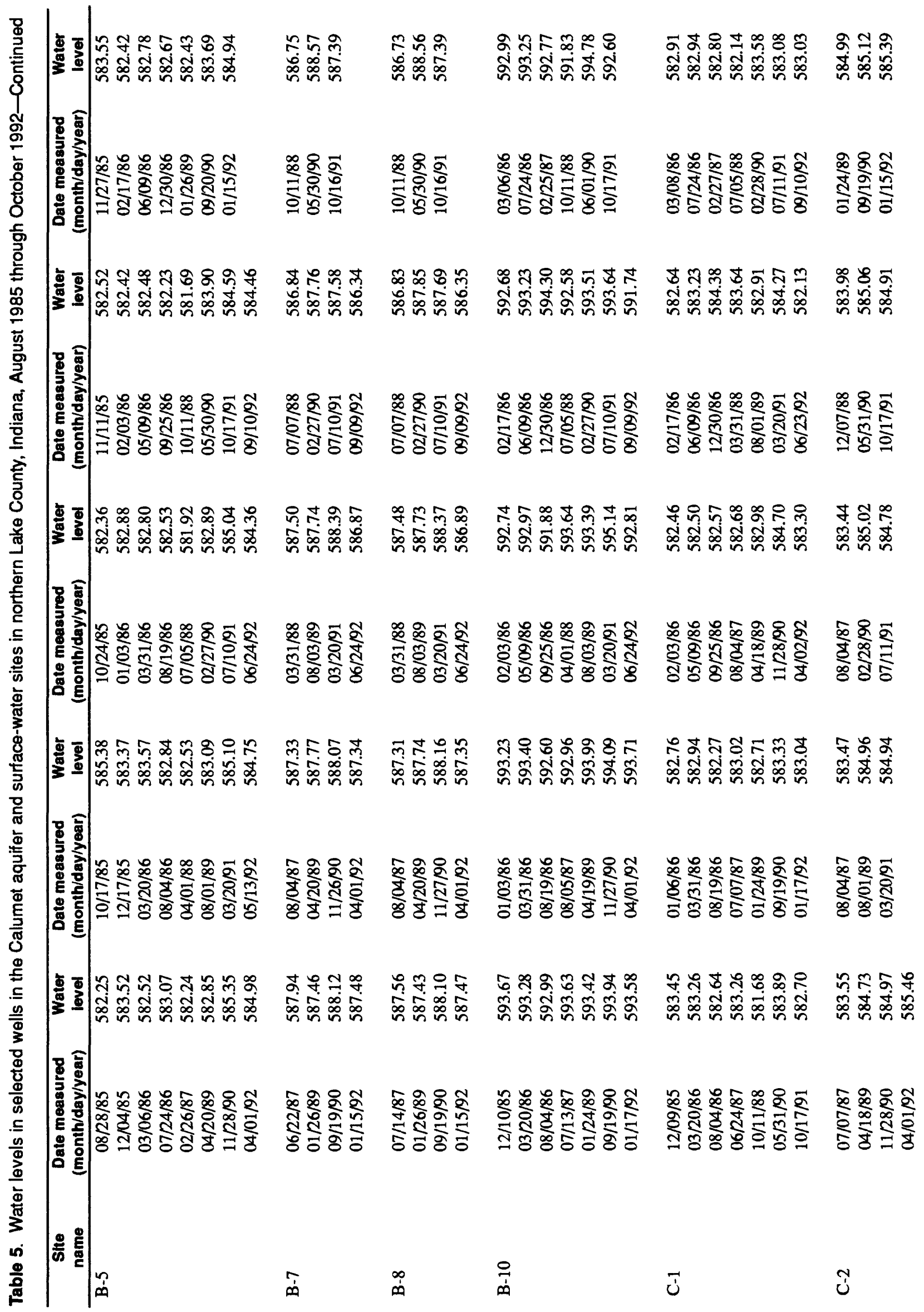




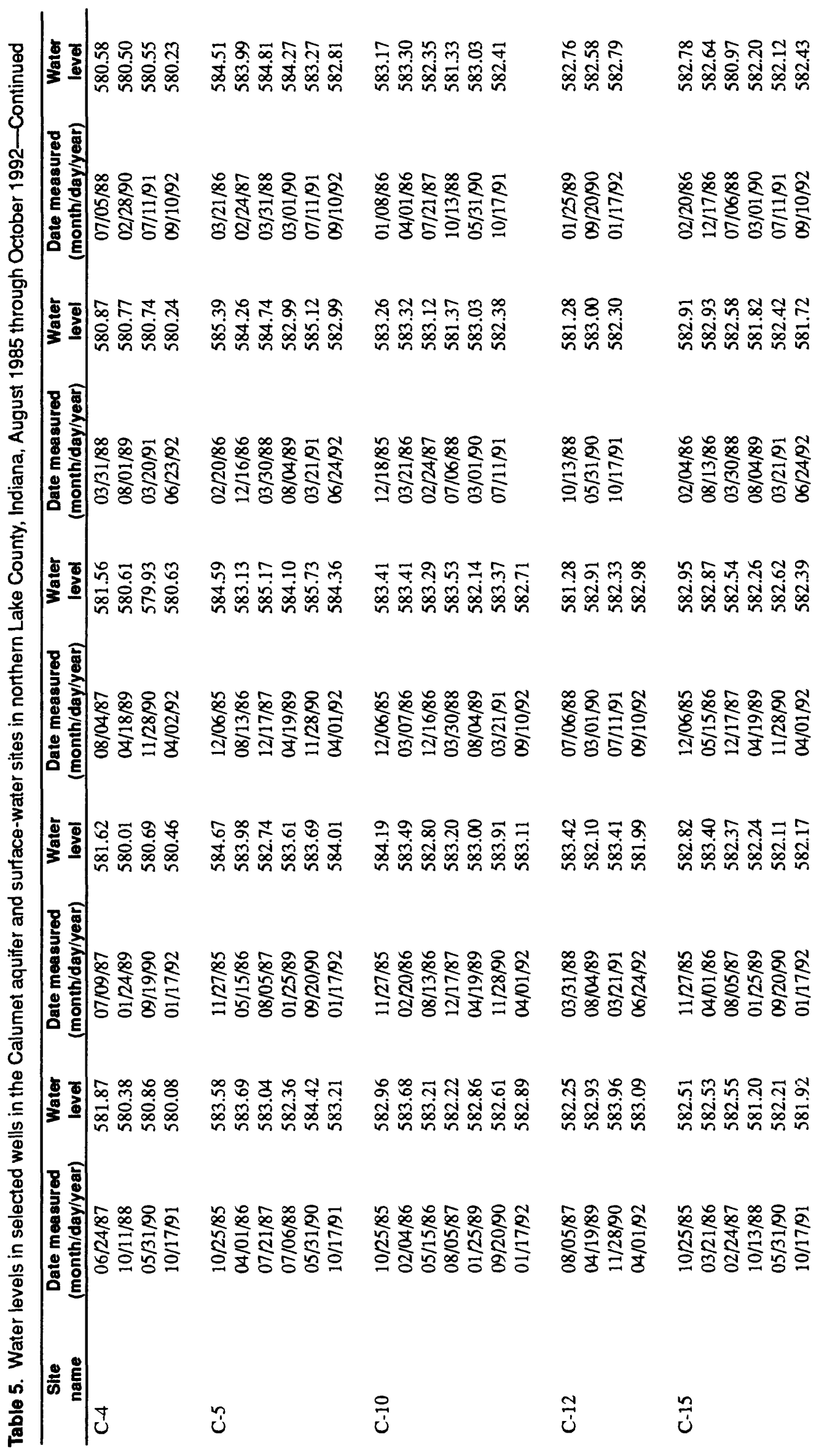




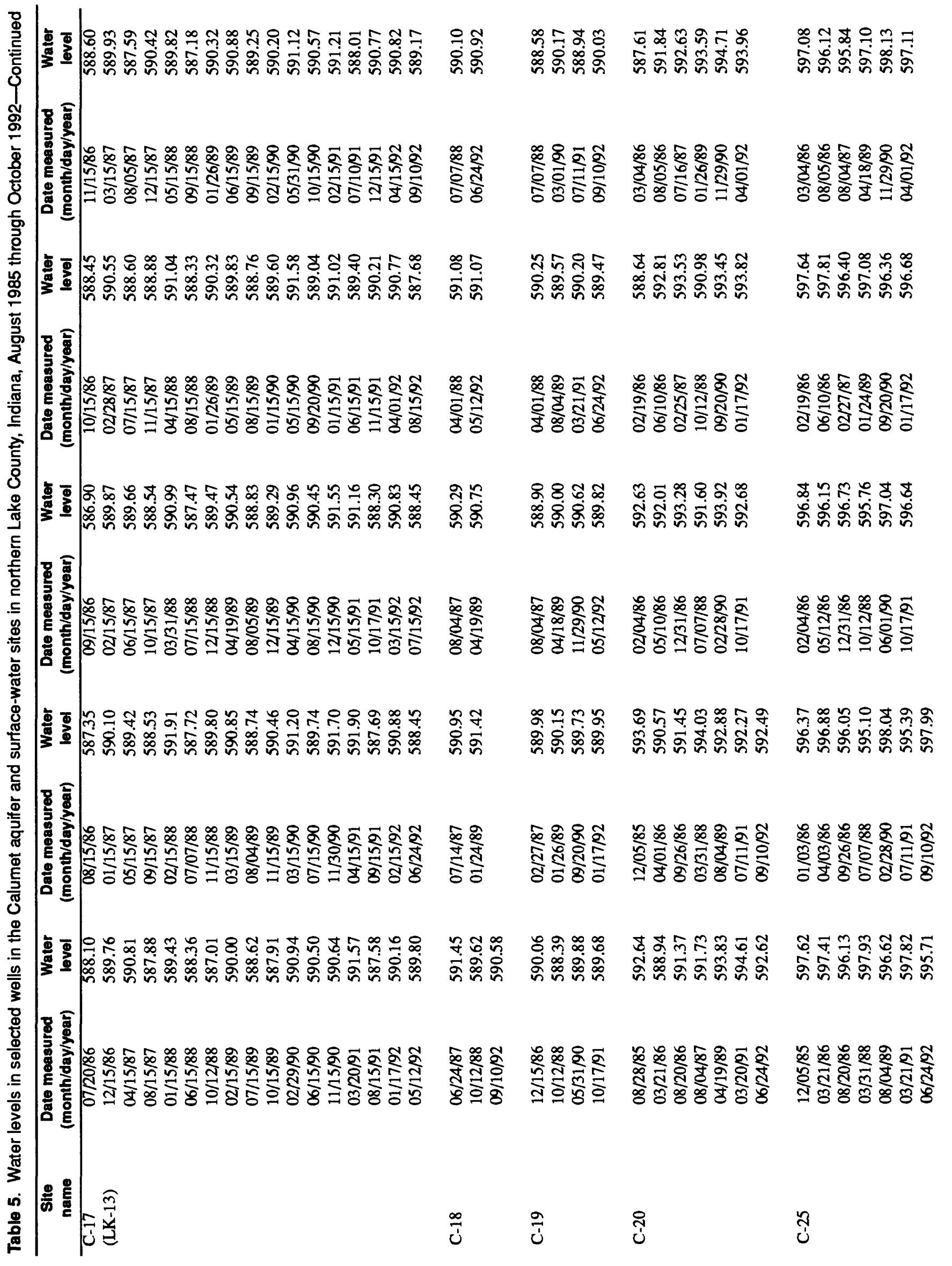




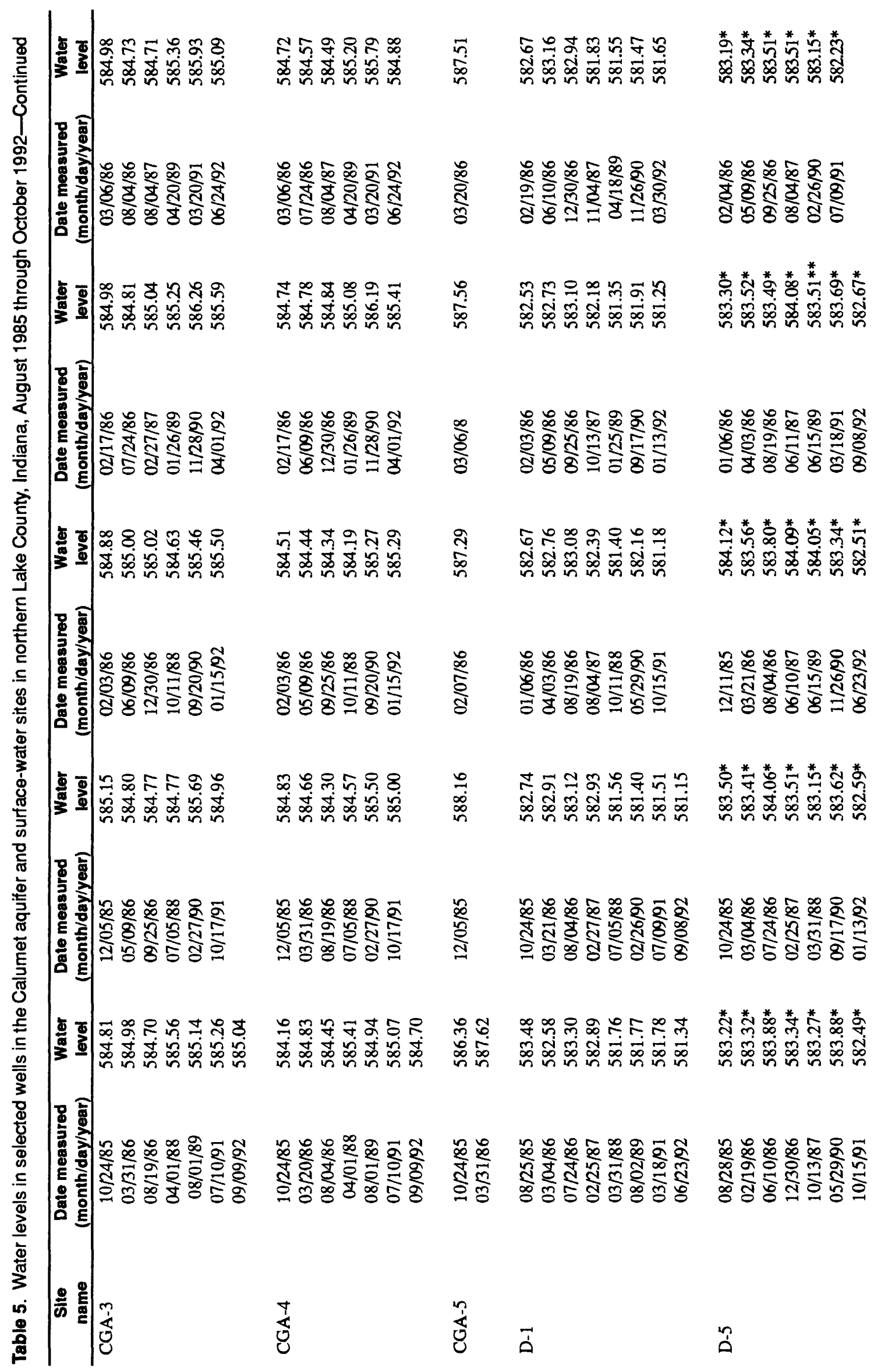




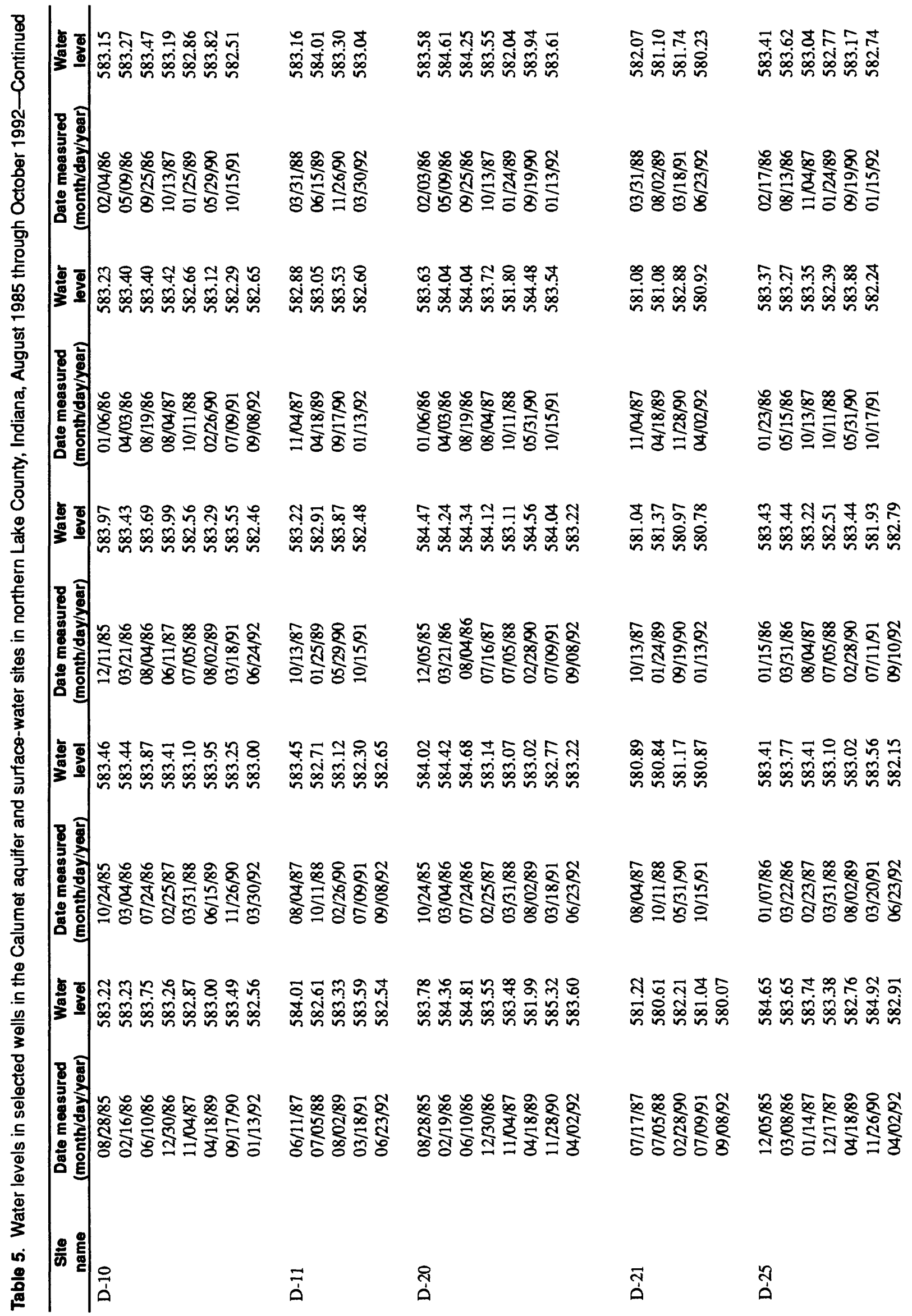




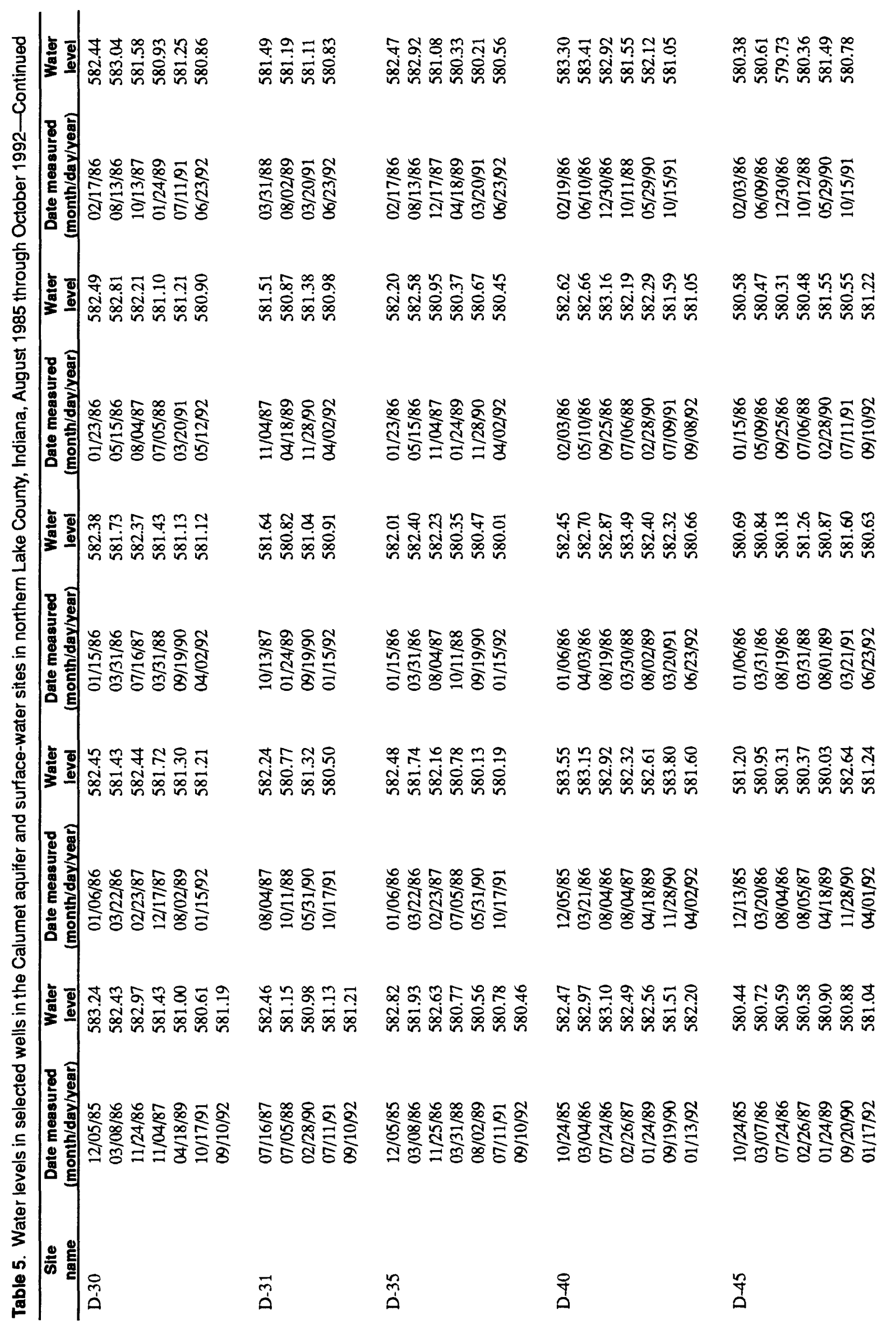




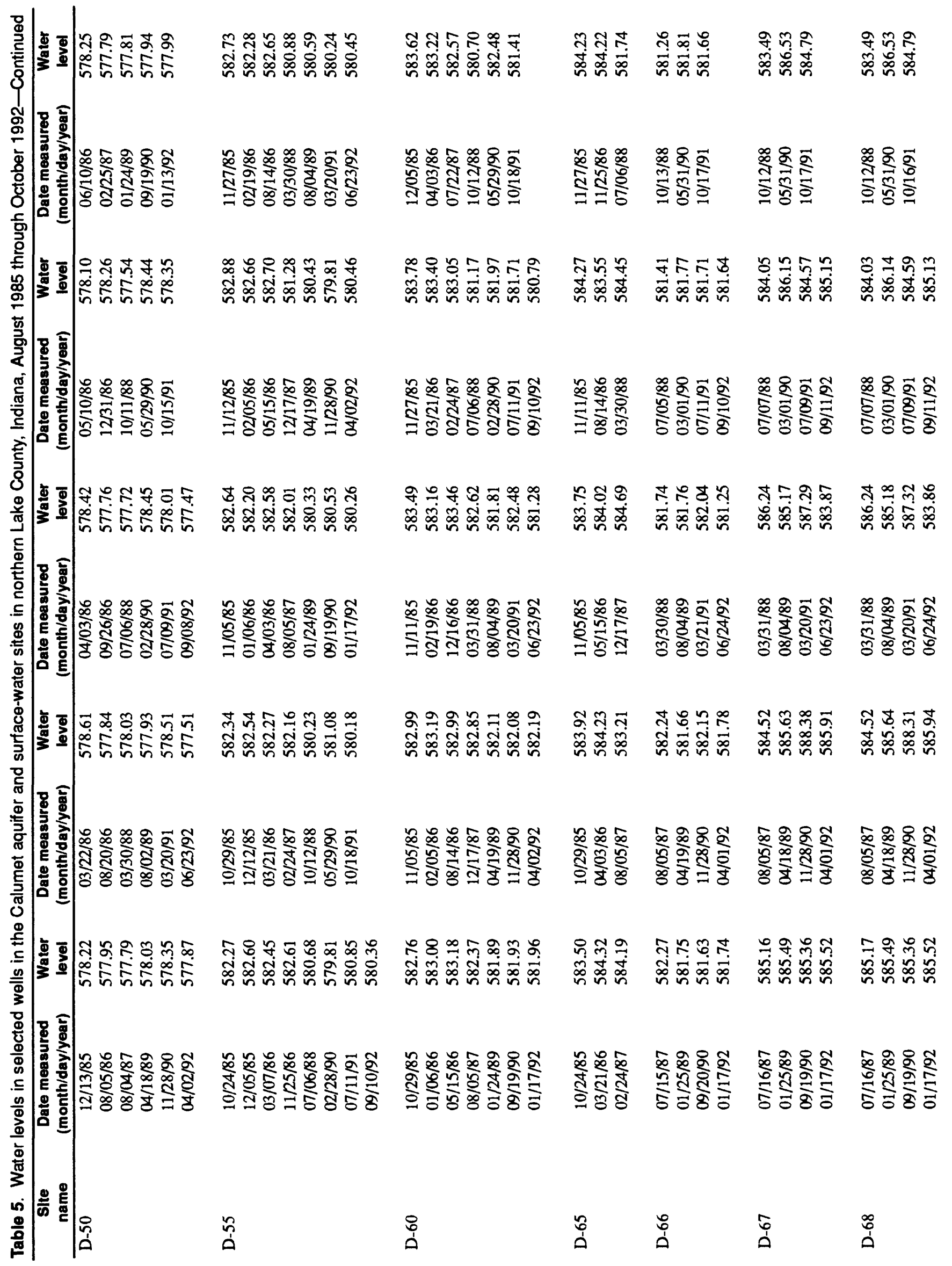




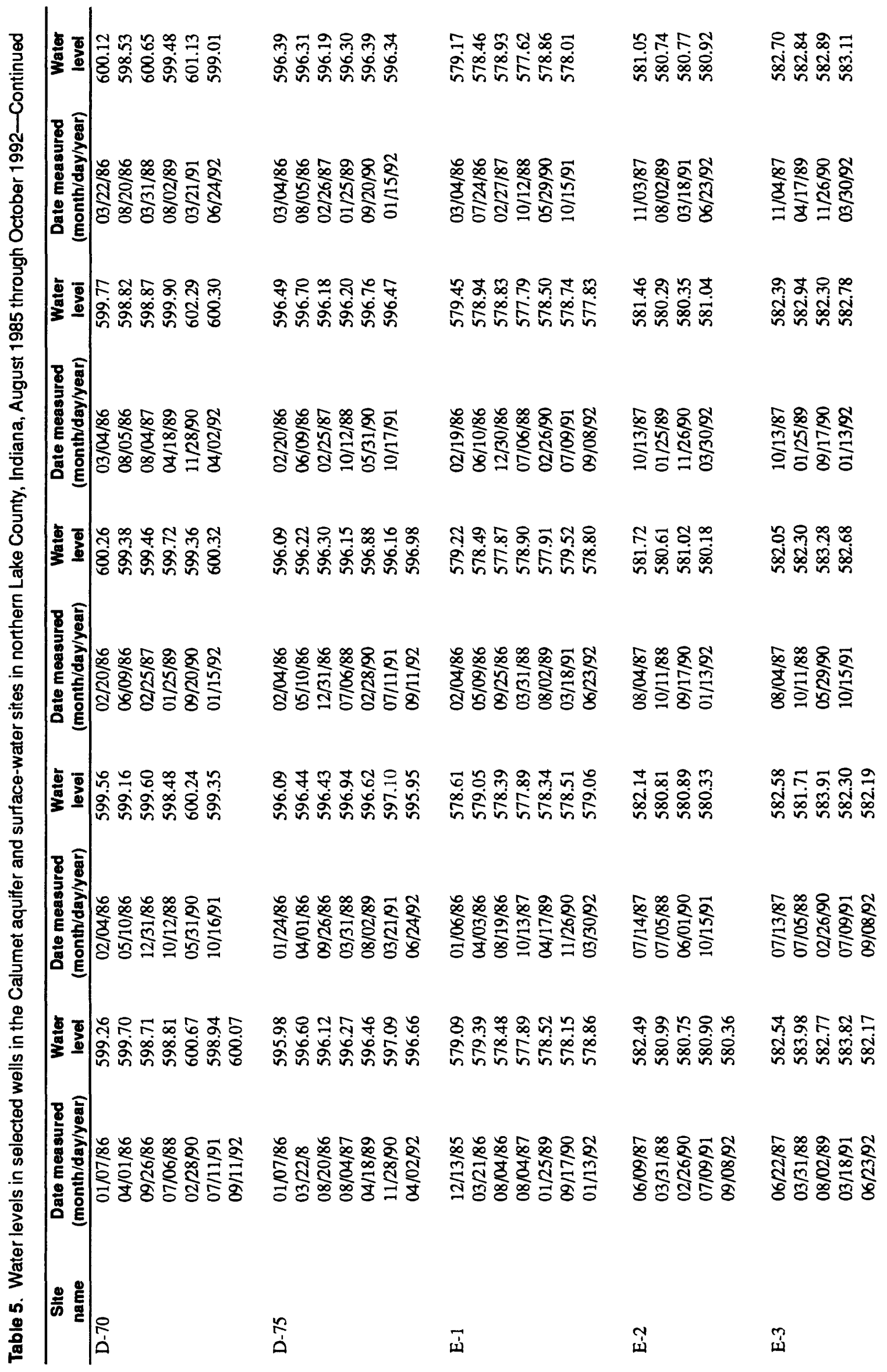




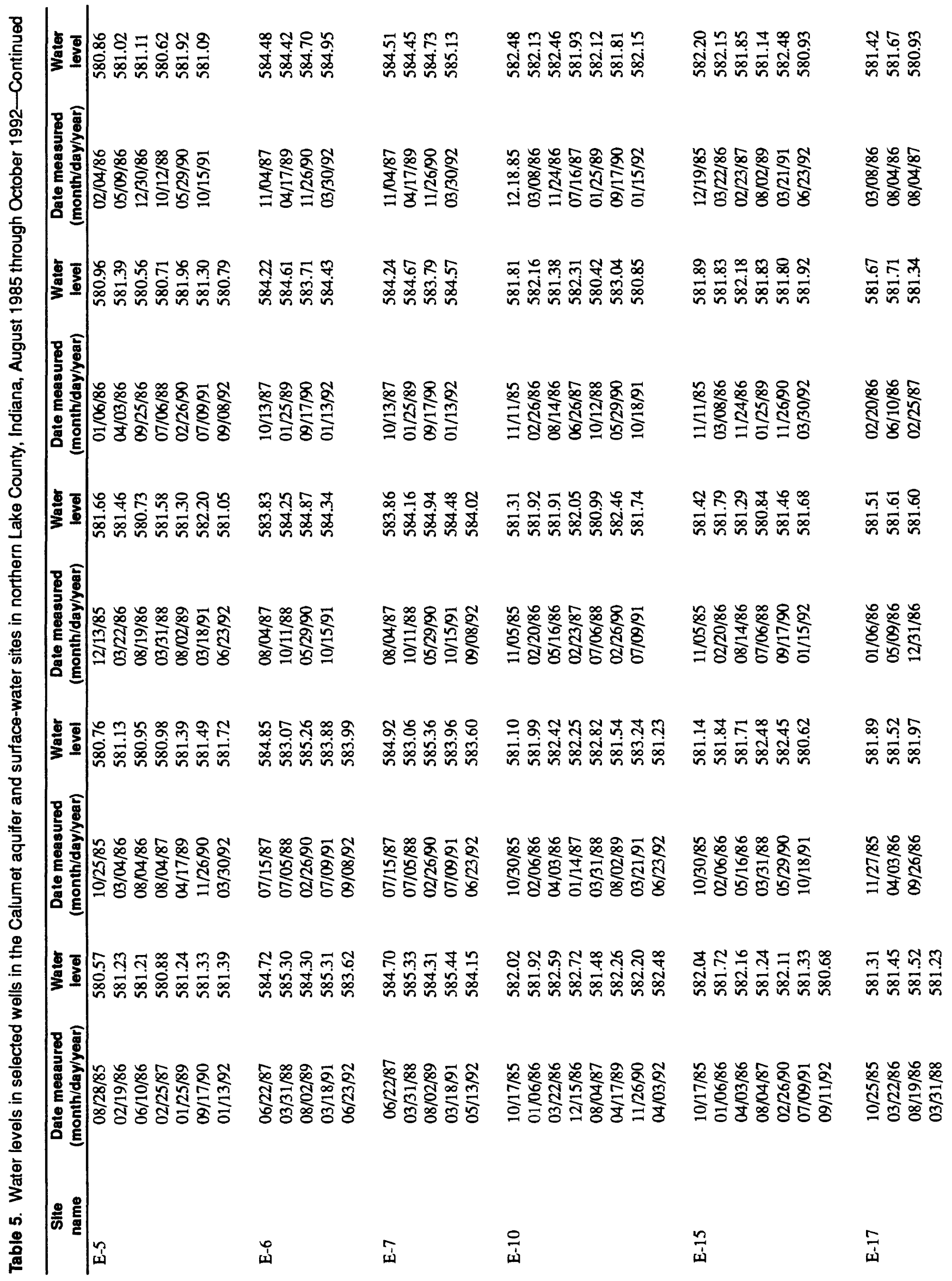




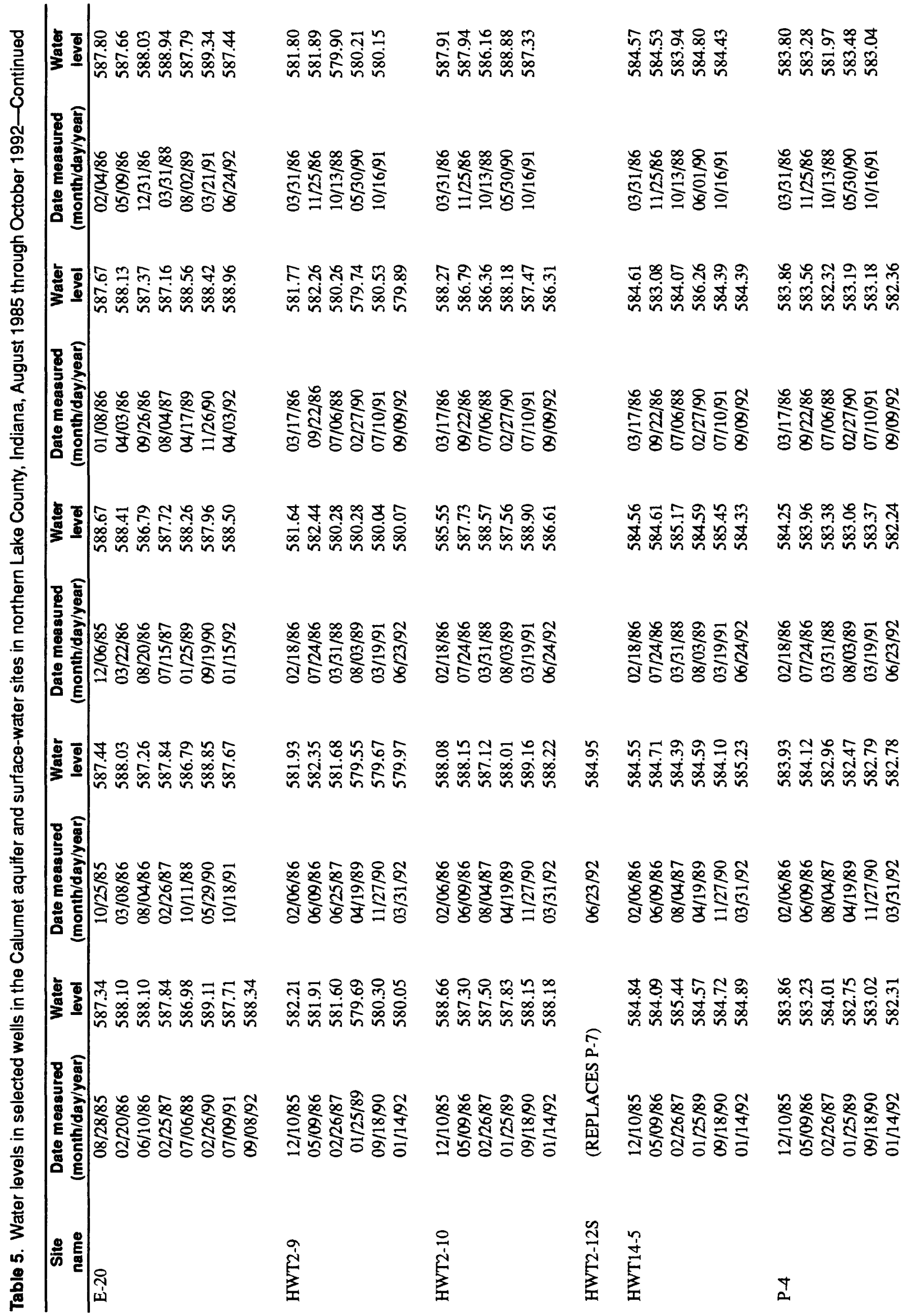




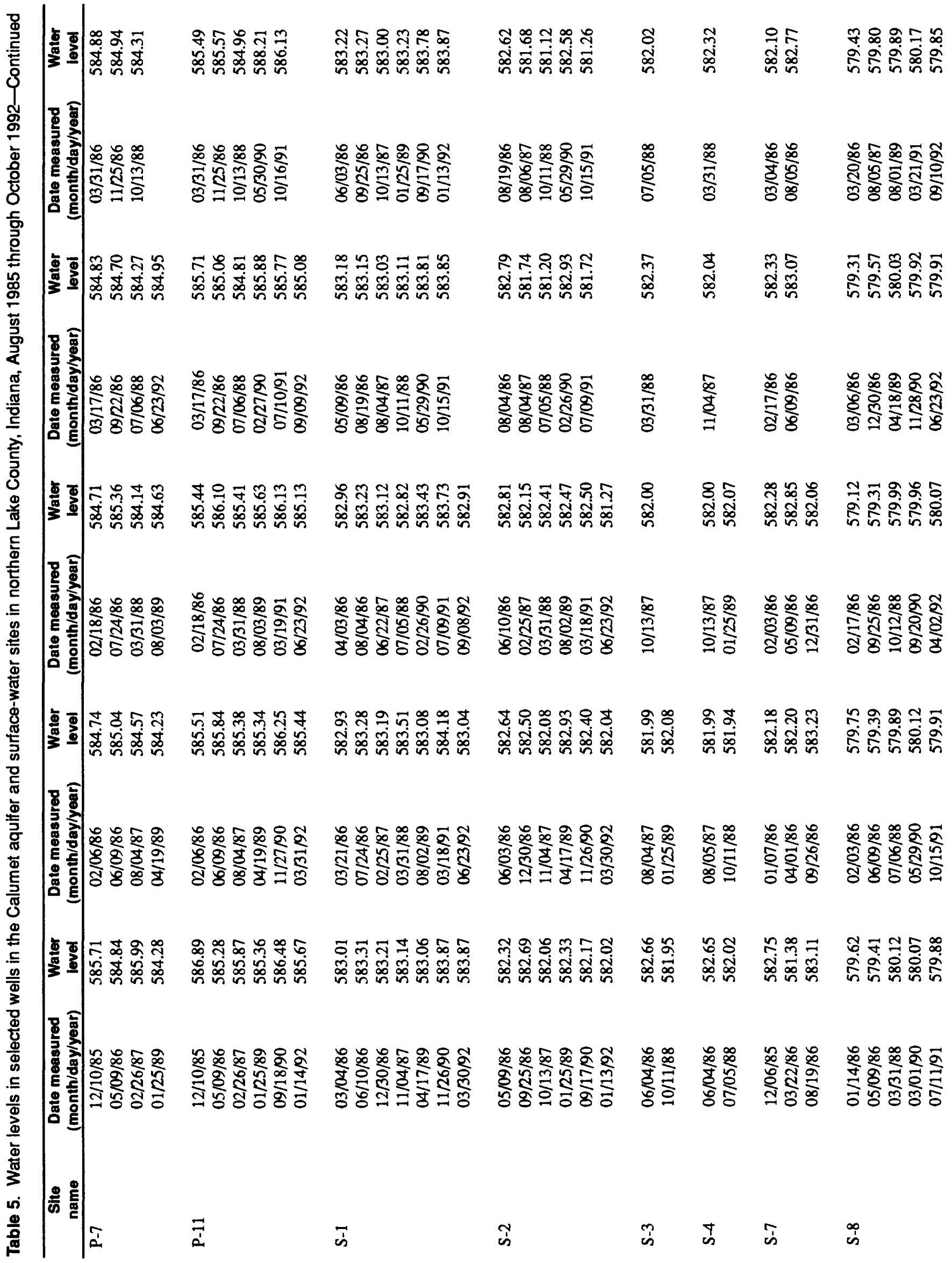




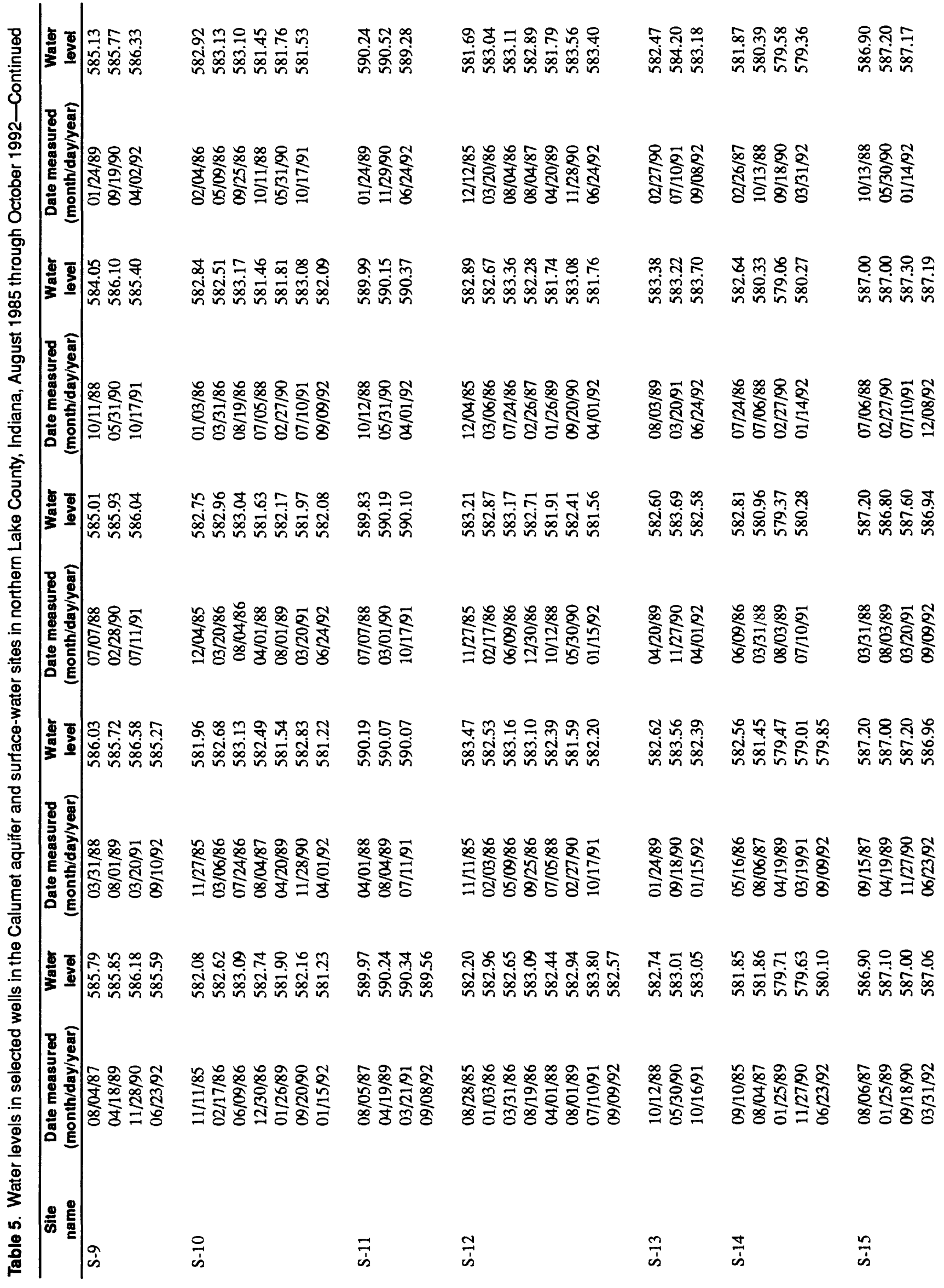




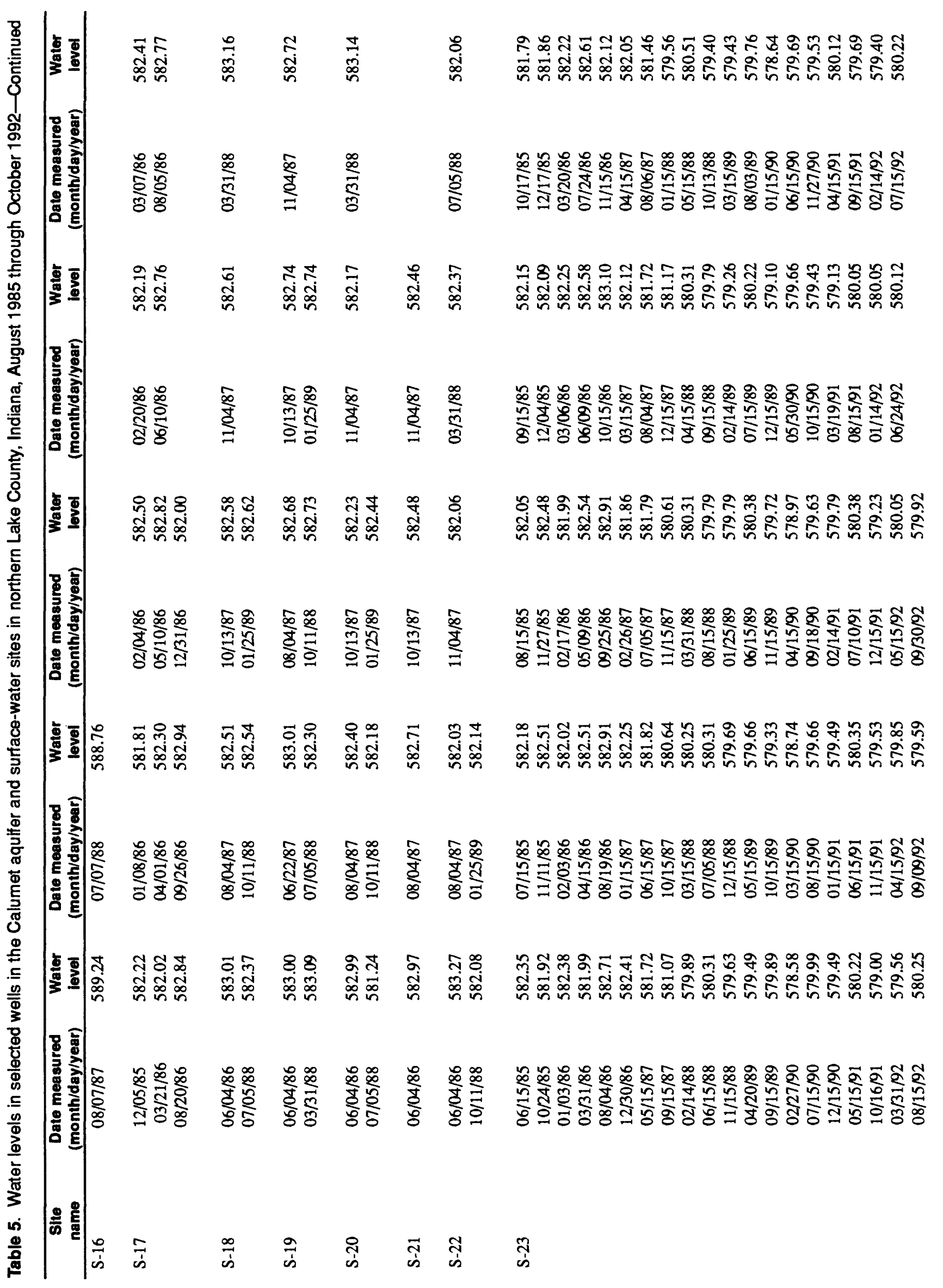




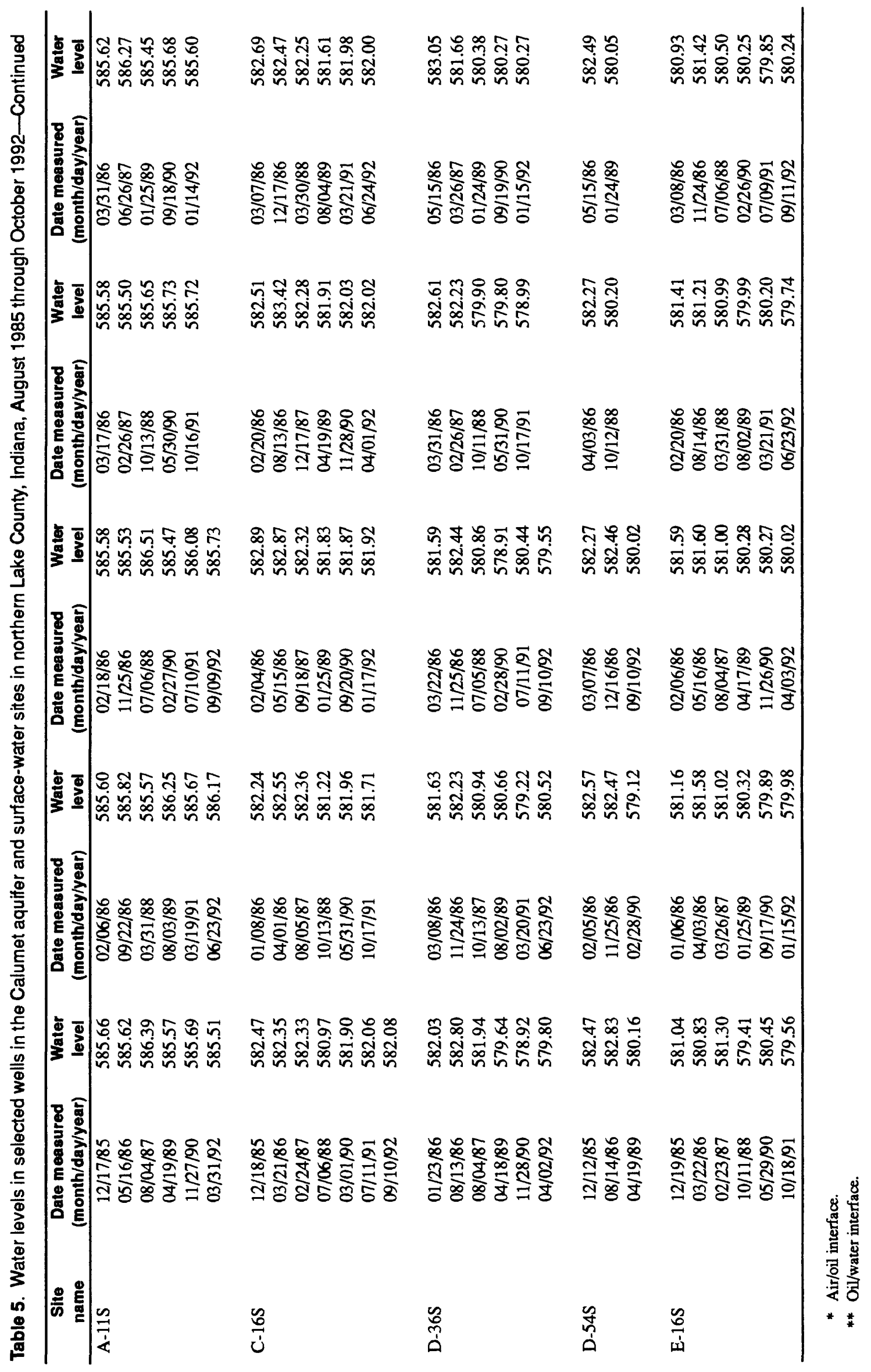

Water Levels in Selected Wells in the Calumet Aquifer and Surface-Water Sites 61 